From the Department of Medicine III, Grosshadern Hospital and HelmholtzZentrum München, Clinical Cooperative Group "Leukemia" Ludwig-Maximilians-University, Munich Chair: Prof. Dr. med. Wolfgang Hiddemann

\title{
Early target genes of CALM/AF10 as revealed by gene expression profiling
}

\author{
Thesis Submitted for a Doctoral degree in Human Biology \\ at the Faculty of Medicine Ludwig-Maximilians-University, \\ Munich, Germany
}

Submitted by

Medhanie Assmelash Mulaw

From

Asmara, Eritrea 
Aus der Medizinischen Klinik und Poliklinik III am Klinikum Großhadern und HelmholtzZentrum München, Klinische Kooperations Gruppe , "Leukämie"

der Ludwig-Maximilians-Universität München, Direktor: Prof. Dr. med. Wolfgang Hiddemann

\title{
Frühe Zielgene von CALM/AF10 identifiziert durch Genexpressionsprofilerstellung
}

\author{
Dissertation zum Erwerb des Doktorgrades der Humanbiologie \\ an der Medizinischen Fakultät der Ludwig-Maximilians- \\ Universität zu München, Deutschland \\ vorgelegt von \\ Medhanie Assmelash Mulaw
}

Aus

Asmara, Eritrea 


\section{Mit Genehmigung der Medizinischen Fakultät der \\ Universität München}

Berichterstatter:

Mitberichterstatter:

Mitbetreuung durch den promovierten Mitarbeiter: Dekan:
Prof. Dr. med. Stefan K. Bohlander

Priv. Doz. Dr. Michael Albert Prof. Dr. Wolfram Dempke

Tag der mündlichen Prüfung: $\quad \underline{27.07 .2009}$ 
To my beloved wife, Blen Tsegaye Aregawi 


\section{Acknowledgement}

I would like to extend my heartfelt gratitude to my supervisor Prof. Dr. med. Stefan K. Bohlander for the opportunity and unreserved support throughout my study. His academic and moral guidance was staggering and conspicuous, without which I couldn't have managed to complete this work in time.

I would also like to acknowledge all the members of the clinical cooperative group (CCG) Leukemia, for the lively and vivid discussions that were quite informative and enlightening. Former and current members of the Prof. Bohlander lab (Belay Tizazu, Deepak Bararia, Alexandre Krause, Luciana-Fontanari Krause, Leticia Fröhlich Archangelo, Philipp Greif, Zlatana Pašalić) are duly acknowledged, whose technical and collegial support was instrumental in the completion of my study.

My deepest gratitude goes to my wife, Blen Tesgaye Aregawi, who has always supported my dreams and encouraged me to fulfill them. Her love and support was pivotal for my study as she patiently and understandingly stayed by my side during my $\mathrm{PhD}$ work, paying a gigantic sacrifice that I am hugely indebted to.

I would also like to thank the German Academic Exchange Program (DAAD) for providing me with the scholarship that made it easy for me to pursue my studies.

My acknowledgement also goes to my home institution, Addis Ababa University (Department of Biology, Faculty of Science), which provided me with a study leave to carry out my $\mathrm{PhD}$ work.

University of Munich and HelmholtzZentrum München are also duly acknowledged. 


\section{Contents}

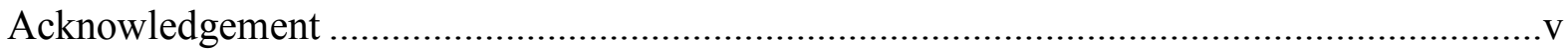

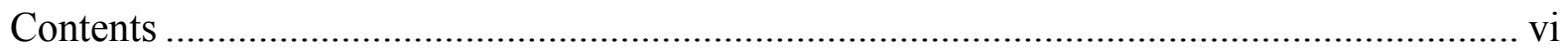

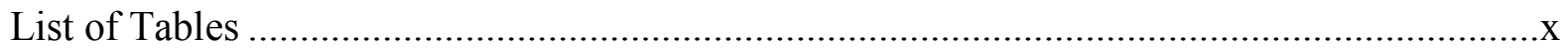

1.1. Genetic basis of cancer.................................................................................

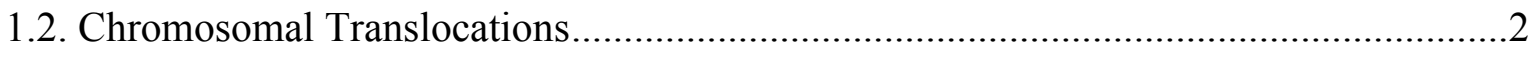

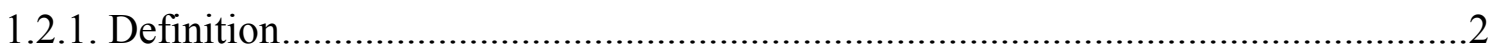

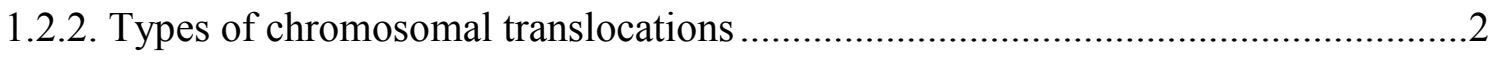

1.2.3. Occurrence of chromosomal translocation ............................................................

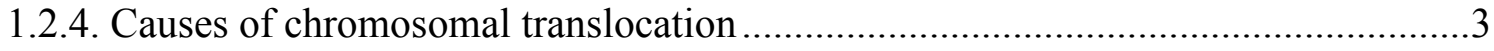

1.2.5. Consequences of chromosomal translocations ............................................

1.3. Chromosomal translocations in hematopoietic malignancies ..................................5

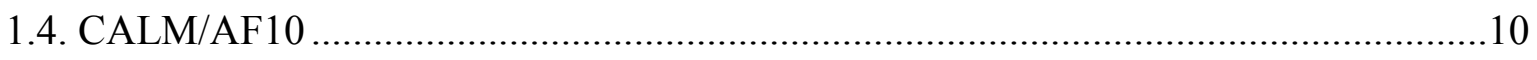

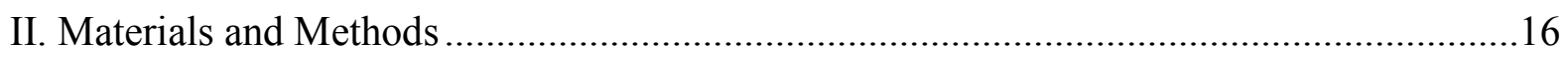

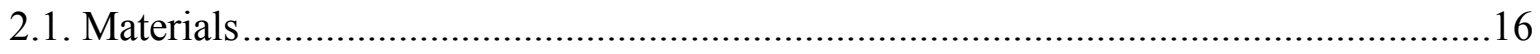

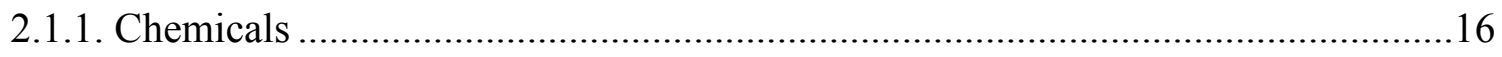

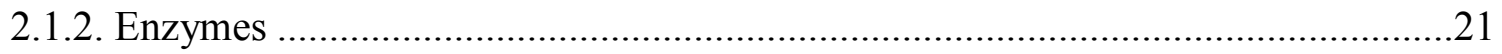

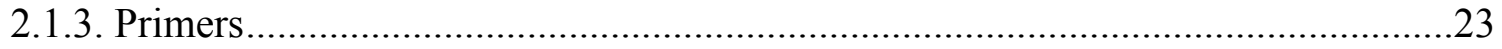

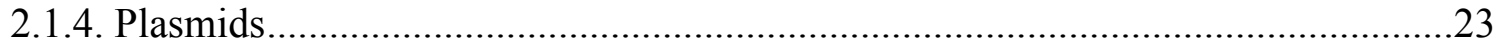

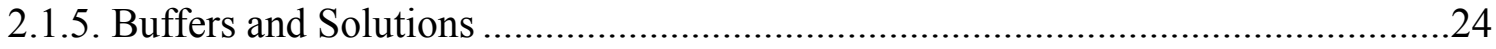

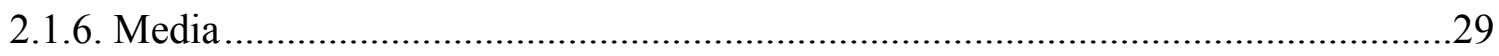

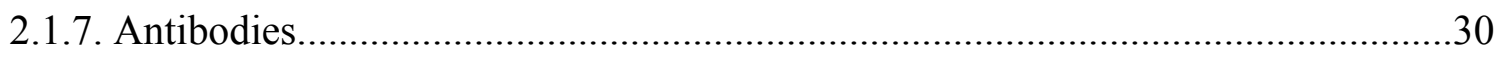

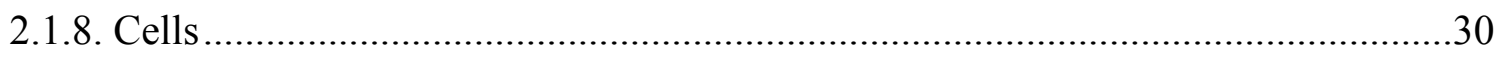

2.1.9. Computer Operating System and Application Software ...................................31

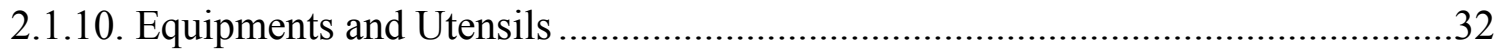




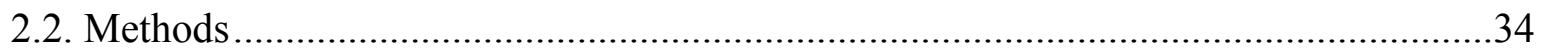

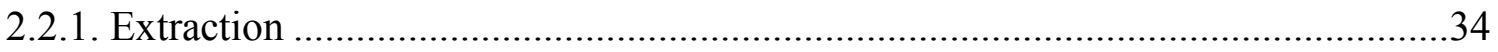

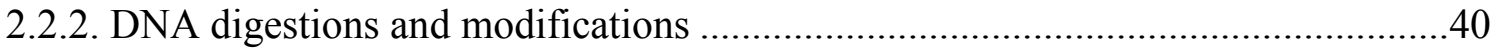

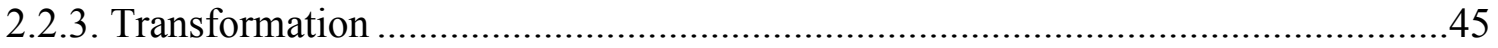

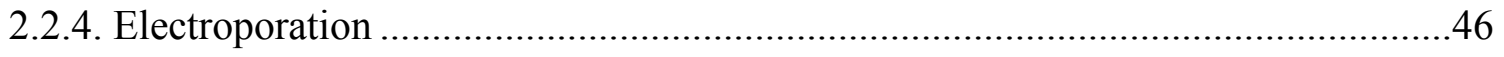

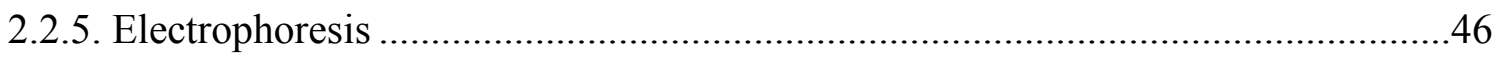

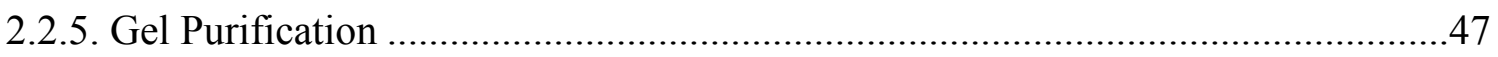

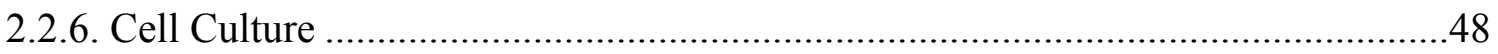

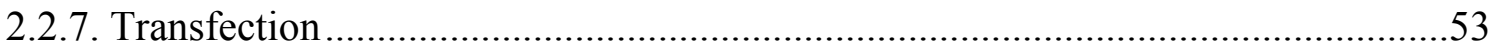

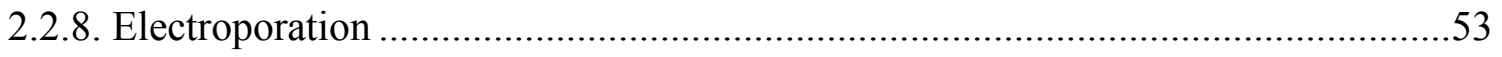

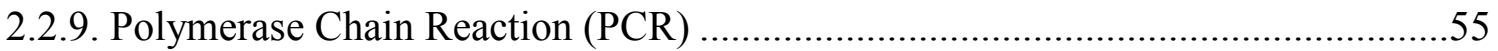

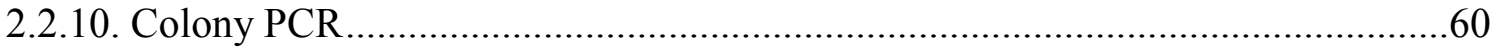

2.2.11. Real Time PCR (Applied Biosystems 7900HT Micro Fluidic Card)...................61

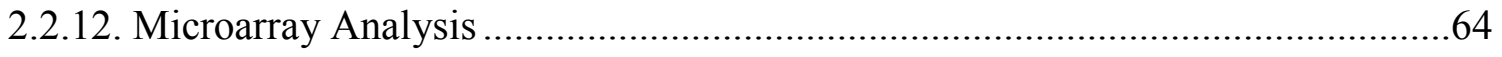

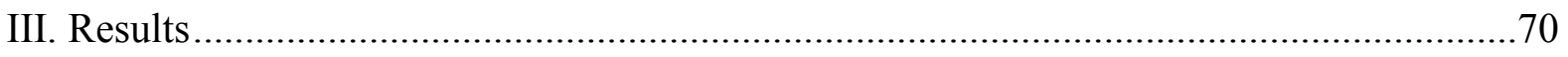

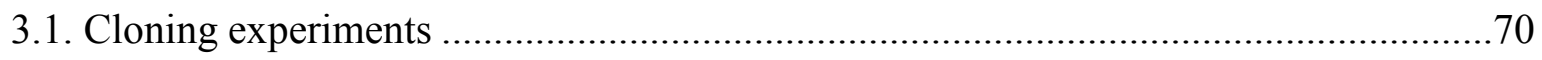

3.1.1. Cloning of FLAG-CALM/AF10 into the pUC19 Shuttle Vector ...........................70

3.1.2. Cloning of VP16 upstream of FLAG-CALM/AF10 .............................................70

3.1.3. Cloning of FLAG-CALM/AF10 and FLAG-VP16-CALM/AF10 into pRTS-1....73

3.2. Establishing a stably transfected cell line ………………….......................................74

3.2.1. Electroporation/transfection ..............................................................................

3.2.2. Selection/enrichment of transfected cells ..............................................................76

3.2.3. Conditional expression ...................................................................................

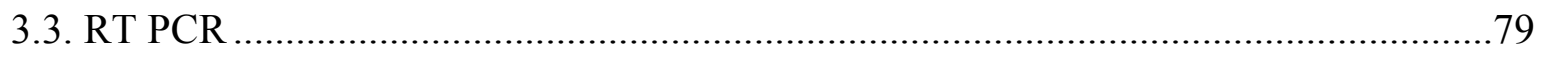

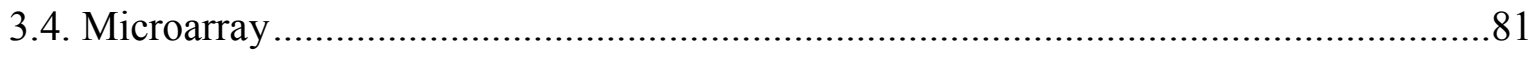




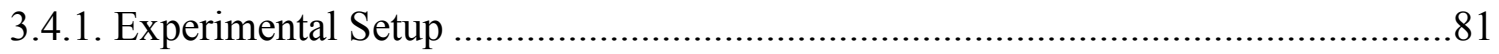

3.4.2. Low-level Analysis of Microarray Data.................................................................. 81

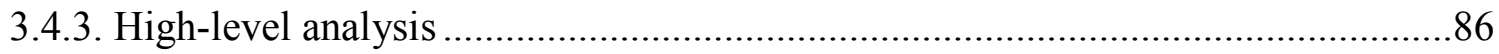

3.4.4. Chromosomal distribution of differentially regulated genes.................................99

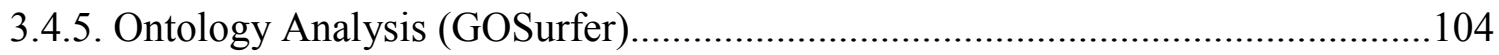

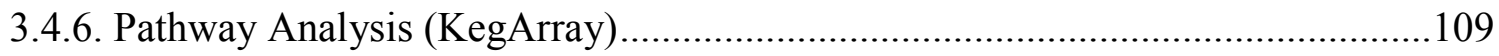

3.4.7. Comparison with patient data (Gene Set Enrichment Analysis, GSEA)..............114

3.5. Verification of Potential Target Genes by Real Time PCR (Taqman ${ }^{\circledR}$ Low Density

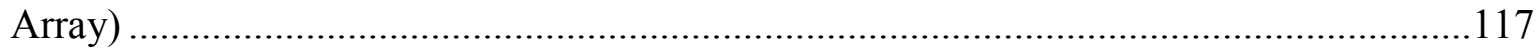

3.5.1. Comparison between array and LDA data ..........................................................121

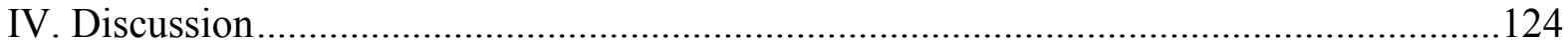

4.1. Some genes implicated in cancer are immediate targets of CALM/AF10 ..................125

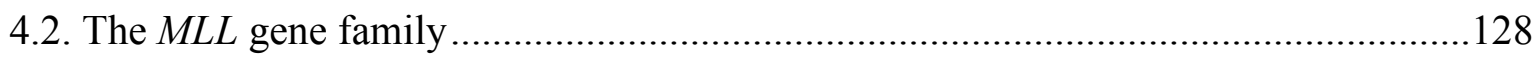

4.3. Important Signalling Pathways are Affected by CALM/AF10 ....................................129

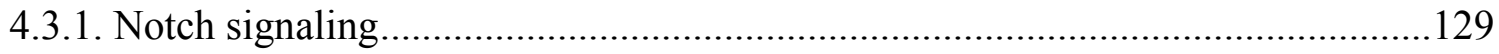

4.4. DNA damage check-point and DNA repair ............................................................130

4.5. Cell cycle is one of the most dramatically affected pathways by CALM/AF10 ….....132

4.6. Genes close to the breakpoint of either AF10 or CALM are not immediate targets of

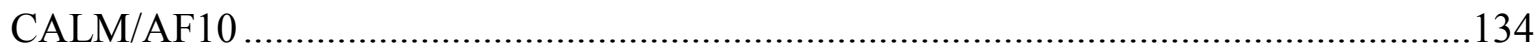

4.7. Genomic instability and DNA repair might be the oncogenic pathway of CALM/AF10 as revealed by comparative pathway analysis of patient and cell line data ........................135

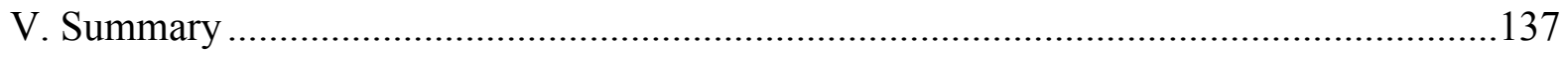

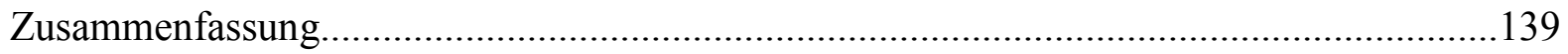

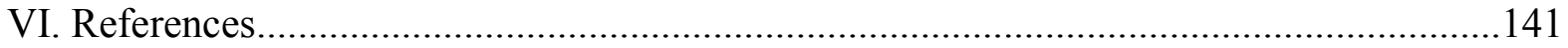

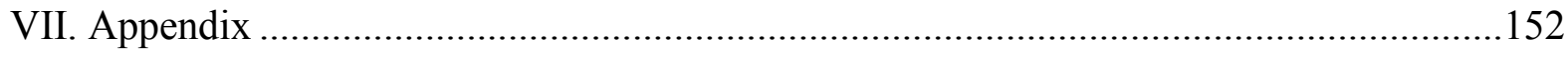

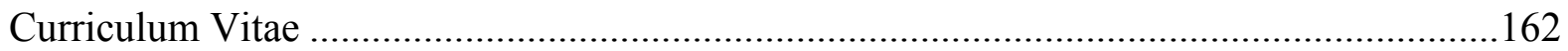





\section{List of Tables}

Table 1.1. Some selected chromosomal translocations involved in hematopoietic malignancies leading to altered gene expression (adapted from Nambiar et al. (2008) with

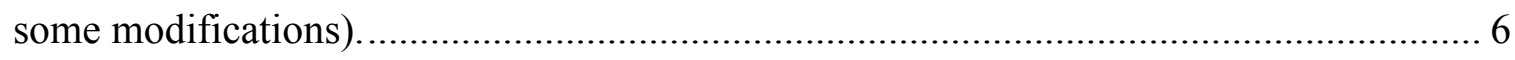

Table 1.2. Some selected chromosomal translocations involved in hematopoietic tumors leading to gene fusions (adapted from Nambiar et al. (2008) with some modifications). . 8

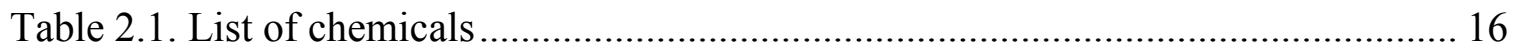

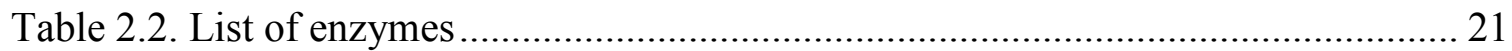

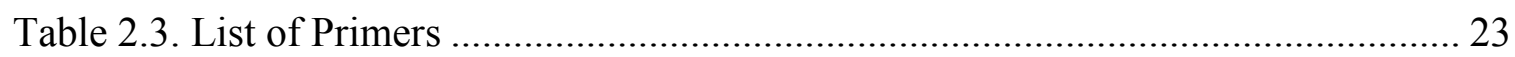

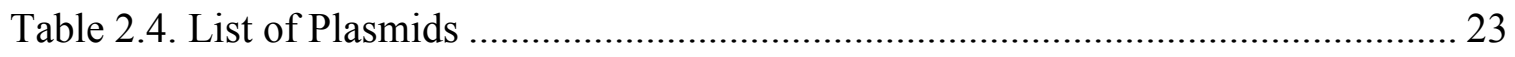

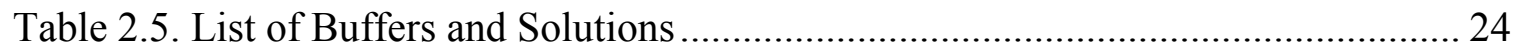

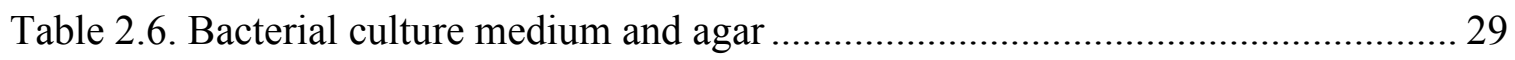

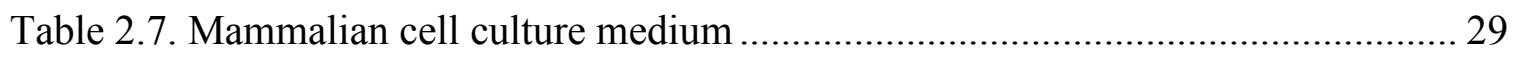

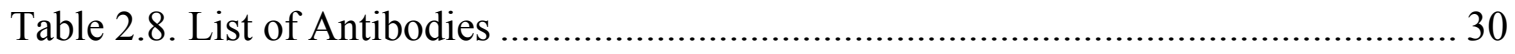

Table 2.9. List of chemo/electro-competent bacteria used for transformation ................. 30

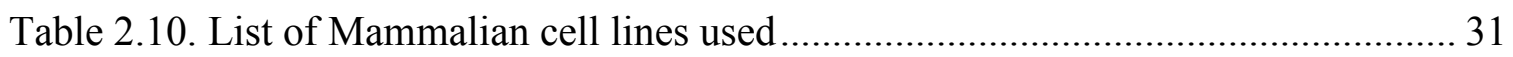

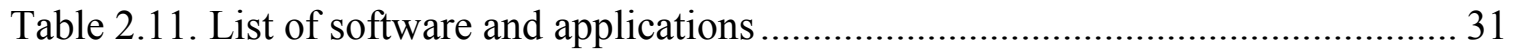

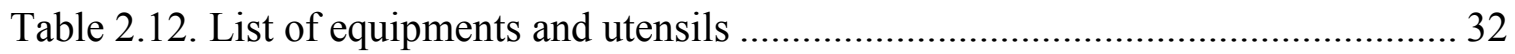

Table 2.13. Typical reaction mix setup for restriction digestion. ................................ 40

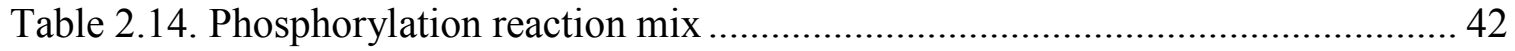

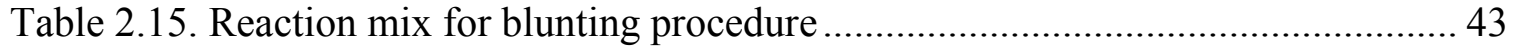

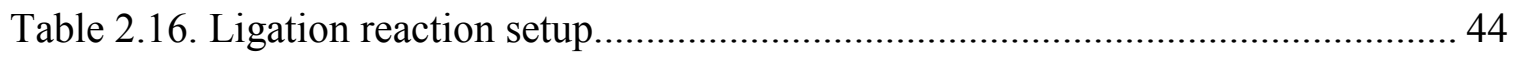

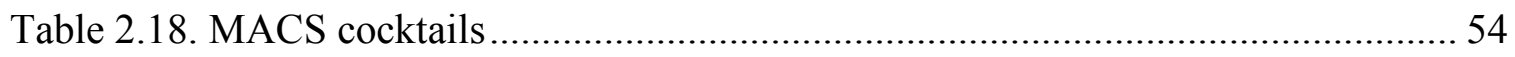

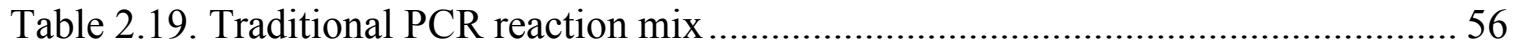

Table 2.20. RT-PCR first reaction mix (Primers, dNTPs and RNA) ............................. 57

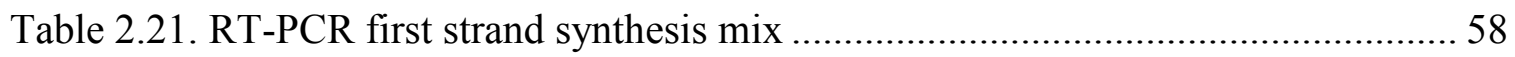

Table 2.21. PCR mix for gene specific amplification from cDNA …........................... 59

Table 2.22. PCR program setup for detection of CALM/AF10 from cDNA preparation 59

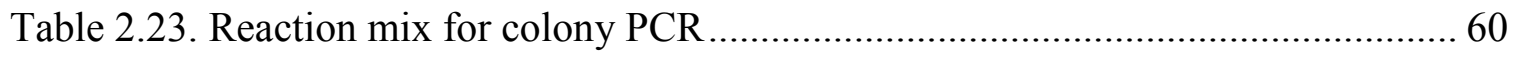




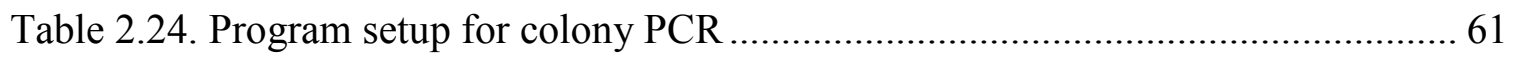

Table 2.25. Sample reaction mix for Low Density Array real-time PCR....................... 62

Table 2.26. List of different LDA cards available from Applied Biosystems ${ }^{\circledR}$................ 62

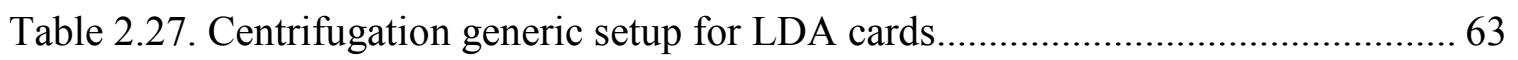

Table 2.28. Applied Biosystems ${ }^{\circledR} 7900 H T$ real-time PCR reaction instrument setup for LDA

Table 3.3. Type of constructs/vectors and amount of DNA used for the electroporation

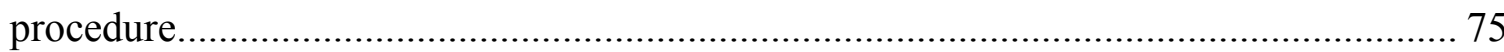

Table. 3.2. Percentage of GFP positive cells after transfection.................................... 76

Table 3.3. Percentage of GFP positive cells after 10 days of puromycin selection.......... 78

Table 3.4. Arrays and their Median Probe Intensity (MPI) ......................................... 83

Table 3.5. Number of differentially regulated genes in different comparisons............... 88

Table 3.6. Correlation table comparing differential expression levels of VP16-

CALM/AF10 expressing cells (pRTS-1-VP16-FLAG-CALM/AF10 24hrs and pRTS-1VP16-FLAG-CALM/AF10 72hrs) and CALM/AF10 expressing cells but without VP16 (pRTS-1-FLAG-CALM/AF10 24hrs and pRTS-1-FLAG CALM/AF10 72hrs)........... 91

Table 3.7. PCA result. The second (\% total variance) and the last column (Cumulative \% of variance) are of particular interest in this table. 96 



\section{Introduction}

\subsection{Genetic basis of cancer}

Worldwide, between 100 and 350 of each 100,000 people die of cancer each year (Lodish et al., 2003). Cancer is due to failures of the mechanisms that usually control the growth and proliferation of cells. During normal development and throughout adult life, intricate genetic control systems regulate the balance between cell birth and death in response to growth signals, growth-inhibiting signals, and death signals.

The loss of cellular regulation that gives rise to most or all cases of cancer are due to genetic damage. Mutations in two broad classes of genes have been implicated in the onset of cancer: proto-oncogenes and tumor suppressor genes (Lodish et al., 2003). Proto-oncogenes are activated to become oncogenes by mutations that cause the gene to be excessively active in growth promotion, which is either due to increased gene expression or production of a hyperactive product. Tumor suppressor genes normally restrain growth, so damage to them allows inappropriate growth. Many of the genes in both classes encode proteins that help regulate cell birth (i.e., entry into and progression through the cell cycle) or cell death by apoptosis; others encode proteins that participate in repairing damaged DNA. Conversion, or activation, of a proto-oncogene into an oncogene generally involves a gain-of-function mutation. At least four mechanisms can produce oncogenes from the corresponding proto-oncogenes:

Point mutations (i.e., change in a single base pair) in proto-oncogenes that resuls in constitutively active protein products 


\section{Introduction}

Chromosomal translocations which fuse two genes together to produce a hybrid gene encoding a chimeric protein whose activity, unlike that of the parent proteins, often is constitutive

Chromosomal translocations which bring a growth regulatory gene under the control of a different promoter that causes inappropriate expression of the gene

Amplification (i.e., abnormal DNA replication) of a DNA segment including a protooncogene, so that numerous copies exist, leading to overproduction of the encoded protein

An oncogene formed by either of the first two mechanisms encodes an "oncoprotein" that differs from the normal protein encoded by the corresponding proto-oncogene. In contrast, the other two mechanisms generate oncogenes whose protein products are identical with the normal proteins; their oncogenic effect is due to production at higher than normal levels or their presence in cells where they normally are not produced (Lodish et al., 2003).

\subsection{Chromosomal Translocations}

\subsubsection{Definition}

Translocation $($ trans $=$ across; location $=$ place) is the term used to describe a rearrangement of chromosome material involving two or more chromosomes.

\subsubsection{Types of chromosomal translocations}

Two types of chromosomal translocations exist:

1. Reciprocal translocations: Reciprocal translocations are the most common type of translocation. These translocations can occur between any of the chromosomes and involve pieces of any size. Pieces of each of these chromosomes have 
changed places and the pieces have become attached to the other chromosome. In this case, where there does not appear to have been any loss or gain of chromosome material, the translocation is described as balanced.

2. Robertsonian translocations: Named after the American insect geneticist who described them, W. R. B. Robertson, Robertsonian translocations only involve exchanges between human chromosome numbers 13,14, 15, 21 and 22. The exchange involves loss of the short arms of two chromosomes and fusion of the remaining two long arms at their centromeres. Robertsonian translocations can also occur between the two chromosomes of the same pair.

\subsubsection{Occurrence of chromosomal translocation}

Though the mechanism and reason underlying chromosomal translocations is not well understood, there are at least two theories (Levitan et al., 2003):

1. Rearrangements occur at random, but selection acts to eliminate those that do not provide the cell with a proliferative advantage

2. Alternatively, certain changes may occur preferentially and, thus, may be the ones that that are observed

\subsubsection{Causes of chromosomal translocation}

Though the cause of chromosomal rearrangement is in most cases not known exactly, one of the main causes is believed to be an exposure to radiation for a prolonged time period. Illegitimate $\mathrm{V}(\mathrm{D}) \mathrm{J}$ recombination, class switch recombination, homologous recombination, non-homologous end joining, and fragile sites all have potential roles in the production of non-random chromosomal translocations (Aplan, 2006). In addition, mutations in DNA repair pathways have been implicated in the production of 


\section{Introduction}

chromosomal translocations in humans, mice, and yeast (Aplan, 2006). Some breakage events in pre- $\mathrm{B}$ or pre-T cells are due to the RAG (recombination activating gene) proteins recognizing heptamer/nonamer-like sequences (Lieber et al., 2008).

\subsubsection{Consequences of chromosomal translocations}

Based on the potential effects that chromosomal translocations might entail, two consequences are noted:

a. enforced oncogene expression that occurs when an oncogene is subjected to a new chromosomal environment such as a very active promoter or enhancer element, or

b. gene fusion between exons of two genes, whereby the two genes affected by the translocation form a fusion gene which gives rise to a fusion protein. 


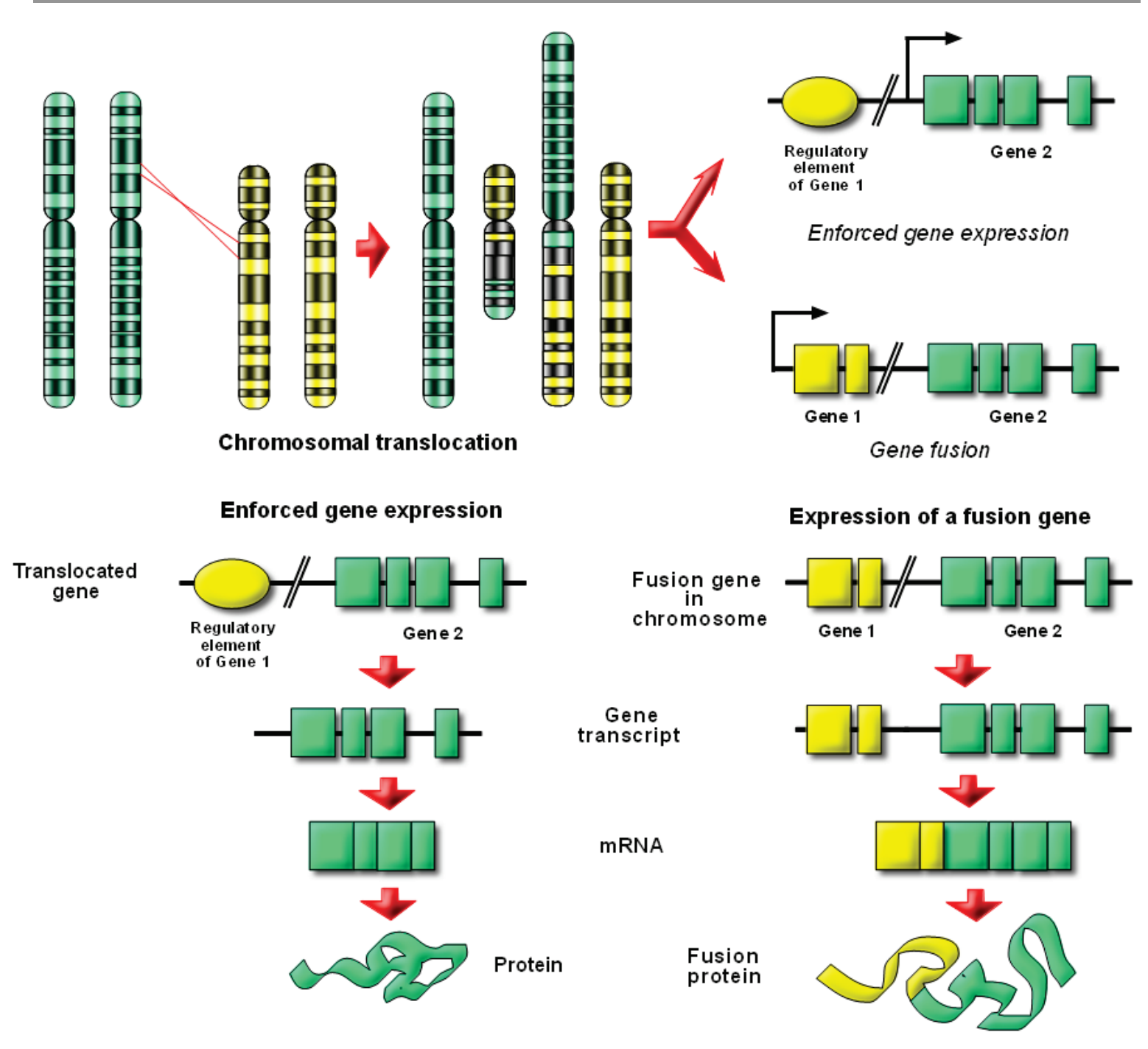

Figure 1.1. Consequences of chromosomal translocations (a) enforced gene expression, (b) fusion gene.

\subsection{Chromosomal translocations in hematopoietic malignancies}

Chromosomal translocations, especially recurrent chromosomal translocations, are requently found in malignancies and play an important role in malignant transformation. As discussed above, translocations can lead to the juxtaposition of the coding region of a gene near the transcriptionally active promoter/enhancer region of another gene, hence leading to over-expression of the former gene (Nambiar et al., 2008). Examples of such events are the IgH-BCL2 and IgH-MYC rearrangements (Korsmeyer, 1992, Rabbitts, 
1991) where BCL2 and MYC show overexpression. Translocations can also result in the formation of a fusion gene. For instance, the $t(9 ; 22)$ translocation results in the fusion of the $A B L 1$ gene on chromosome 9 with the $B C R$ gene on chromosome 22 , thereby forming the fusion gene due to the formation of a unique in-frame fusion mRNA and protein (Rowley, 2001, Rowley and Potter, 1976, Rowley, 1973). The BCR/ABL fusion gene is under the control of the BCR promoter. Table 1.1 and table 1.2 give lists of the different translocation events and their consequences.

Table 1.1. Some selected chromosomal translocations involved in hematopoietic malignancies leading to altered gene expression (adapted from Nambiar et al. (2008) with some modifications).

\begin{tabular}{|c|c|c|c|c|}
\hline $\begin{array}{l}\text { Type of } \\
\text { translocation }\end{array}$ & Affected gene & $\begin{array}{l}\text { Type of } \\
\text { tumor }\end{array}$ & $\begin{array}{l}\text { Mechanism of } \\
\text { activation }\end{array}$ & References \\
\hline $\mathrm{t}(8 ; 14)(\mathrm{q} 24 ; \mathrm{q} 32)$ & c-myc(8q24) & BL, B-ALL & $\begin{array}{l}\text { Relocation to } \lg \mathrm{H} \\
\text { locus }\end{array}$ & $\begin{array}{l}\text { Rabbits et al., Adv Immun, } \\
\text { 1991. 50:119-146 }\end{array}$ \\
\hline $\mathrm{t}(7 ; 19)(q 35 ; p 13)$ & $|y| 1(19 p 13)$ & T-ALL & $\begin{array}{l}\text { Relocation to } \\
\text { TCR- } \beta \text { locus }\end{array}$ & $\begin{array}{l}\text { Mellentin et al., Cell, } 1989 . \\
\text { 58: 77-83 }\end{array}$ \\
\hline $\mathrm{t}(1 ; 14)(\mathrm{p} 32 ; \mathrm{q} 11)$ & tal1/scl(1p32) & T-ALL & $\begin{array}{l}\text { Relocation to } \\
\text { TCR- } \alpha \text { Locus }\end{array}$ & $\begin{array}{l}\text { Baer et al., Sem. Cancer } \\
\text { Biol., 1993. 4:341-347 }\end{array}$ \\
\hline $\mathrm{t}(11 ; 14)(p 15 ; q 11)$ & rbtn1/ttg1(11p15) & T-ALL & $\begin{array}{l}\text { Relocation to } \\
\text { TCR-ס Locus }\end{array}$ & $\begin{array}{l}\text { Boehm et al., EMBO J, } 1988 . \\
\text { 7:385-94 } \\
\text { McGuire et al., Mol. Cell. Biol, } \\
\text { 1989. 9:2124-32 } \\
\text { Boehm et al., PNAS, USA, } \\
\text { 1991. 88:4367-71 }\end{array}$ \\
\hline $\mathrm{t}(10 ; 14)(\mathrm{q} 24 ; \mathrm{q} 11)$ & hox11(10q24) & T-ALL & $\begin{array}{l}\text { Relocation to } \\
\text { TCR- } \alpha / \beta \text { locus }\end{array}$ & $\begin{array}{l}\text { Lu et al., Genes Chr Cancer, } \\
\text { 1990. 2:217-22 }\end{array}$ \\
\hline
\end{tabular}


Kagan et al., PNAS, USA,

1989. $86: 4161-5$

Zutter et al., PNAS, USA,

1990. 87:3161-5

\begin{tabular}{|c|c|c|c|c|}
\hline $\mathrm{t}(11 ; 14)(\mathrm{q} 13 ; \mathrm{q} 32)$ & $\mathrm{Bcl} 1(11 \mathrm{q} 13)$ & B-CLL & $\begin{array}{l}\text { Relocation to } \lg \mathrm{H} \\
\text { locus }\end{array}$ & $\begin{array}{l}\text { Tsujimoto et al., Science, } \\
\text { 1984. 224:1403-6 }\end{array}$ \\
\hline & & & & $\begin{array}{l}\text { Tsujimoto et al., Nature, } \\
\text { 1985. 315:340-3 } \\
\text { Welzel et al., Cancer Res., } \\
\text { 2001. 61: 1629-1636 }\end{array}$ \\
\hline $\mathrm{t}(5 ; 14)(\mathrm{q} 31 ; \mathrm{q} 32)$ & IL-3(5q31) & pre-B-ALL & $\begin{array}{l}\text { Relocation to } \lg \mathrm{H} \\
\text { locus }\end{array}$ & $\begin{array}{l}\text { Grimaldi et al., Blood, } 1989 . \\
\text { 73:2081-2085 } \\
\text { Meeker et al., Blood, } 1990 . \\
\text { 76:285-289 }\end{array}$ \\
\hline $\mathrm{t}(1 ; 7)(\mathrm{p} 34 ; \mathrm{q} 34)$ & $\operatorname{lck}(1 \mathrm{p} 34)$ & T-ALL & $\begin{array}{l}\text { Relocation to } \\
\text { TCR- } \beta \text { Locus }\end{array}$ & $\begin{array}{l}\text { Tycko et al., J. Exp. Med., } \\
\text { 1991. 174:867-873 }\end{array}$ \\
\hline $\mathrm{t}(\mathrm{X} ; 14)(q 28 ; q 11)$ & C6.1B(Xq28) & T-PLL & $\begin{array}{l}\text { Relocation to } \\
\text { TCR-a locus }\end{array}$ & $\begin{array}{l}\text { Stern et al., Oncogene, } 1993 . \\
\text { 8:2475-2483 }\end{array}$ \\
\hline $\mathrm{t}(14 ; 21)(\mathrm{q} 11 ; \mathrm{q} 22)$ & bhlhb1(21q22) & pre-T-LBL & $\begin{array}{l}\text { Relocation to } \\
\text { TCRA/D locus }\end{array}$ & $\begin{array}{l}\text { Wang et al., PNAS, 2000. 97: } \\
3497-3502\end{array}$ \\
\hline
\end{tabular}


Table 1.2. Some selected chromosomal translocations involved in hematopoietic tumors leading to gene fusions (adapted from Nambiar et al. (2008) with some modifications).

\begin{tabular}{|c|c|c|c|}
\hline Type of translocation & Type of tumor & Genes involved & References \\
\hline \multirow[t]{2}{*}{$\mathrm{t}(8 ; 21)(\mathrm{q} 22 ; \mathrm{q} 22)$} & AML-M2 & $\mathrm{AML} 1 / \mathrm{CBF} \alpha(21 \mathrm{q} 22)$ and & Ohki M, Sem. Cancer Biol., \\
\hline & & ETO/MTG $\beta(8 q 22)$ & 1993. 4:369-376 \\
\hline \multirow[t]{2}{*}{$\mathrm{t}(15 ; 17)(\mathrm{q} 21 ; \mathrm{q} 21)$} & APL & PML (15q21) and RARA & Gillard et al., Sem. Cancer \\
\hline & & $(17 q 21)$ & Biol., 1993. 4:359-368 \\
\hline \multirow[t]{2}{*}{$\mathrm{t}(8 ; 16)(\mathrm{p} 11 ; \mathrm{p} 13)$} & AML & $\operatorname{MOZ}(8 p 11)$ and & Borrow J et al., Nat Genet., \\
\hline & & CBP(16p13) & 1996. 14:33-41 \\
\hline \multirow[t]{2}{*}{$\mathrm{t}(9 ; 22)(\mathrm{q} 34 \mathrm{q} 11.2)$} & CML/ALL & $\mathrm{BCR}(22 \mathrm{q} 11)$ and C- & de Klein et al., Nature, \\
\hline & & $A B L(9 q 34)$ & 1982. 300:765-767 \\
\hline \multirow[t]{2}{*}{$\mathrm{t}(11 ; 17)(\mathrm{q} 23 ; \mathrm{q} 21.1)$} & AML-M3 & PLZF (11q23) and RARA & Chen et al., EMBO J., \\
\hline & & $(17 q 21)$ & 1993. 12:1161-1167 \\
\hline \multirow[t]{2}{*}{$\mathrm{t}(9 ; 11)(\mathrm{p} 22 ; \mathrm{q} 23)$} & AML-M4, pre-B-ALL & MLL (11q23) and AF9 & Nakamura et al., PNAS, \\
\hline & & $(9 p 22)$ & 1993. 90: 4631-4635 \\
\hline \multirow[t]{2}{*}{$\mathrm{t}(6 ; 11)(q 27 ; q 23)$} & AML-M5, ALL & MLL (11q23) and AF6 & Prasad et al., Cancer Res., \\
\hline & & $(6 q 27)$ & 1993. 53:5624-5628 \\
\hline \multirow[t]{2}{*}{$\mathrm{t}(6 ; 9)(\mathrm{p} 23 ; q 34)$} & AML-M1,M2,M4,M5 & DEK (6p23) and CAN & von Lindern, Mol. Cell Biol., \\
\hline & & $(9 q 34)$ & 1992. 12:1687-1697 \\
\hline \multirow[t]{2}{*}{$\mathrm{t}(16 ; 21)(\mathrm{p} 11 ; q 22)$} & AML & FUS(16p11) and & Shimizu et al., PNAS, \\
\hline & & $\mathrm{ERG}(21 \mathrm{q} 22)$ & 1993. 90:10280-10284 \\
\hline \multirow[t]{2}{*}{$\mathrm{t}(16 ; 21)(\mathrm{q} 24 ; \mathrm{q} 22)$} & t-AML, MDS & AML1(21q22) and & Gamou T et al., Blood, \\
\hline & & MTG(16q24) & 1998. 91:4028-4037. \\
\hline \multirow[t]{2}{*}{$\mathrm{t}(12 ; 22)(\mathrm{p} 13 ; \mathrm{q} 11-12)$} & MDS & ETV6(12p13)/TEL and & Buijs A et al., Oncogene, \\
\hline & & MN1(22q11) & 1995. 10:1511-1519 \\
\hline
\end{tabular}




\begin{tabular}{|c|c|c|c|}
\hline$t(12 ; 21)(p 12-13 ; q 22)$ & Pre-B-ALL & $\begin{array}{l}\text { TEL(12p12) and } \\
\text { AML1(21q22) }\end{array}$ & $\begin{array}{l}\text { Romana et al., Blood, } \\
\text { 1995. 86:4263-4269 } \\
\text { Golub et al., Proc. Natl. } \\
\text { Acad. Sci. USA, 1995. 92: } \\
\text { 4917-4921 }\end{array}$ \\
\hline$t(4 ; 11)(q 21 ; q 23)$ & Pre-B-ALL & $\begin{array}{l}\mathrm{MLL}(11 \mathrm{q} 23) \text { and } \\
\mathrm{AF} 4(4 \mathrm{q} 21)\end{array}$ & $\begin{array}{l}\text { Djabali et al., Nature } \\
\text { Genet., 1992. 2: 113-118 } \\
\text { Gu et al., Cell, } 1992 . \\
\text { 71:701-708 }\end{array}$ \\
\hline $\mathrm{t}(11 ; 19)(q 23 ; p 13)$ & Pre-B-ALL, T-ALL & $\begin{array}{l}\operatorname{MLL}(11 q 23) \text { and } \\
\operatorname{ENL}(19 p 13)\end{array}$ & $\begin{array}{l}\text { Tkachuk et al., Cell, } 1992 . \\
\text { 71:691-700 } \\
\text { Yamamoto et al., } \\
\text { Oncogene, 1993. 8: 2617- } \\
2625\end{array}$ \\
\hline $\mathrm{t}(2 ; 5)(p 23 ; q 35)$ & ALCL (NHL) & $\begin{array}{l}\text { NPM (5q35) and ALK } \\
(2 p 23)\end{array}$ & $\begin{array}{l}\text { Morris et al., Science, } \\
\text { 1994. 263:1281-1284 }\end{array}$ \\
\hline $\operatorname{inv}(16)(p 13 q 22)$ & AML, MDS at times & MYH11 & $\begin{array}{l}\text { Bernard et al.,Leukemia, } \\
\text { 1989. } 3 \text { (10) : 740-745. } \\
\text { Campbell et al., 1991, } \\
\text { Genes, chromosomes \& } \\
\text { cancer.3 (1) : 55-61. }\end{array}$ \\
\hline$t(10 ; 11)(p 12 ; q 14)$ & pre-T-ALL, AML & $\begin{array}{l}\text { CALM (11q14) and } \\
\text { AF10(10p12) }\end{array}$ & $\begin{array}{l}\text { Dreyling et al., Proc. Natl. } \\
\text { Acad. Sci. USA. 1996. 93, } \\
\text { 4804-4809. }\end{array}$ \\
\hline
\end{tabular}




\subsection{CALM/AF10}

The $\mathrm{t}(10 ; 11)(\mathrm{p} 12 ; \mathrm{q} 14)$ is a recurring chromosomal translocation that is found in acute myeloid and acute lymphoblastic leukemia as well as in malignant lymphoma (Dreyling et al., 1996). This translocation results in the fusion of AF10 (Chaplin et al., 1995), a putative zinc finger transcription factor containing an N-terminal LAP/PHD zinc finger motif, a nuclear localization signal, an AT-hook domain, and a leucine zipper and with the CALM gene (Clathrin assembly protein lymphoid myeloid leukemia gene) that encodes a clathrin assembly protein.

(Linder et al., 2000, Saha et al., 1995) have identified a novel protein-protein interaction motif in the AF10 protein comprising the extended LAP/PHD-finger domain that mediates homo-oligomerisation of recombinant AF10 and is conserved in several proteins, including MLL itself. AF10 binds cruciform DNA via a specific interaction with an AT-hook motif and is localized to the nucleus by a defined bipartite nuclear localization signal in the N-terminal region (Linder et al., 2000). Furthermore, it has recently been shown that PHD domains interact with H3K4me3 (Li et al., 2006, Peña et al., 2006), potentially playing a crucial role in transcription initiation as $\mathrm{H} 3 \mathrm{~K} 4 \mathrm{me} 3$ modifications have recently been shown to be associated with gene expression (Barski et al., 2007).

CALM (for Clathrin Assembly Lymphoid Myeloid; also known as PICALM) is located on chromosome 11q23, is ubiquitously expressed and encodes a 652 amino acid protein with multiple domains involved in endocytosis (Dreyling et al., 1996). These domains include the epsin N-terminal homology (ENTH) domain (Asp-Pro-Phe), a DPF (ASPPro-Phe) motif, an NPF (Asn-Pro-Phe) motif and type I and II clathrin-binding sequences 
(CBS I and II) (Anika Meyerholz, 2005, Tebar et al., 1999, Klebig et al., 2003). The predicted CALM protein is similar to the neuronal specific monomeric clathrin assembly protein AP180, which was first identified in coated vesicles of bovine brain (S Ahle and Ungewickell, 1986, Takei et al., 1996). CALM homologues have been identified in rat, mouse and cow.

The CALM/AF10 fusion mRNA codes for the CALM/AF10 fusion protein which contains almost the complete CALM protein fused in frame to about $90 \%$ of the AF10 protein without the $\mathrm{N}$ terminal two PHD zinc fingers (Dreyling et al., 1996) (See figures 2 and 3). In the monocytic cell line U937 both the CALM/AF10 and the AF10/CALM fusion mRNAs can be identified (Dreyling et al., 1996). CALM/AF10 chimeric transcripts (six isoforms of the CALM/AF10 fusion transcripts and five of AF10/CALM) were detected by RT-PCR in hematological malignancies with $\mathrm{t}(10 ; 11)(\mathrm{p} 13 ; \mathrm{q} 14)$ in patient samples including ALL, AML and lymphoblastic lymphoma, and in three monocytic cell lines (P31/Fujioka, KP-Mo-TS and U937) (Ashihara et al., 2007, Narita et al., 1999).

CALM/AF10 is highly Leukemogenic. CALM/AF10 leads to the development of an aggressive acute leukemia with in a murine bone marrow transplant model (Deshpande et al., 2006). According to Deshpande et al. (2006), all mice $(\mathrm{n}=13)$ transplanted with highly purified GFP+ CALM/AF10 (murine stem cell virus (MSCV)-based retroviral construct carrying the CALM/AF10 cDNA upstream of an internal ribosomal entry site (IRES)-green fluorescence protein (GFP) cassette) transduced cells (median retroviral transduction efficiency of 5.7, range 1.2\%-16.4\%) with or without non-transduced helper 
cells developed the disease after a median of 110 days post-transplantation (range 46-

366).

(a)

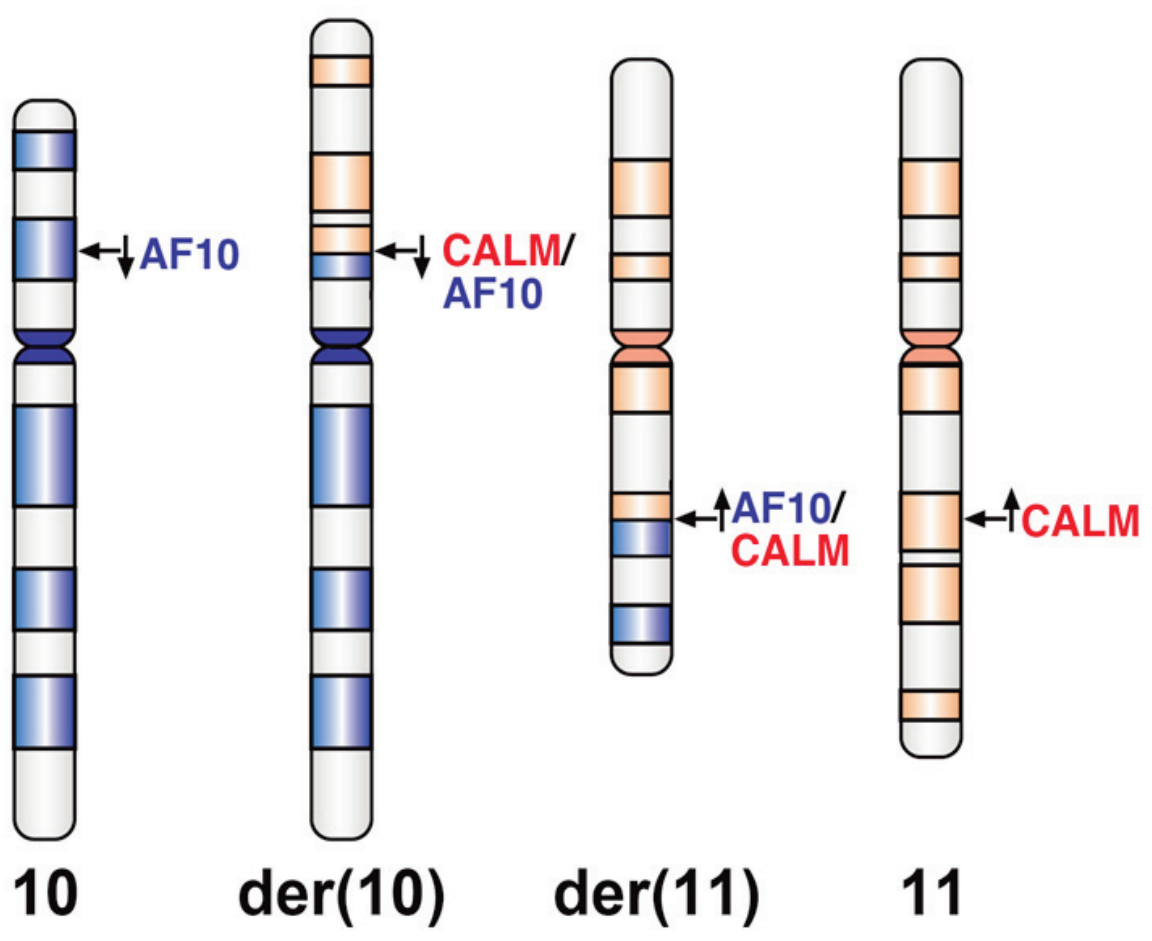

(b)
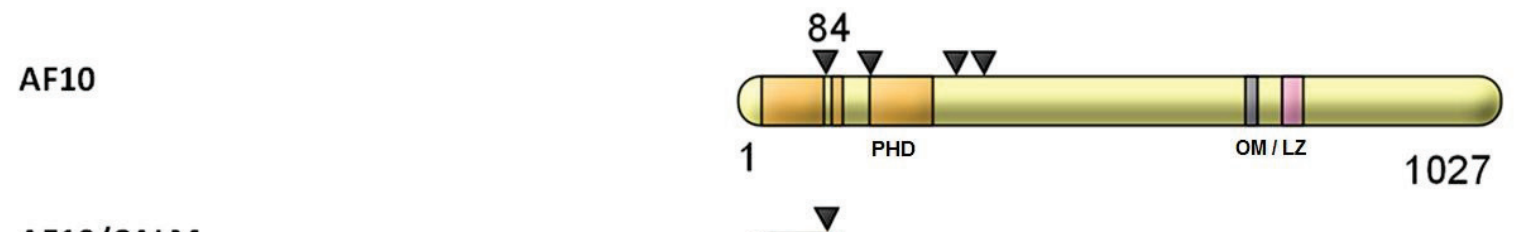

AF10/CALM

CALM/AF10

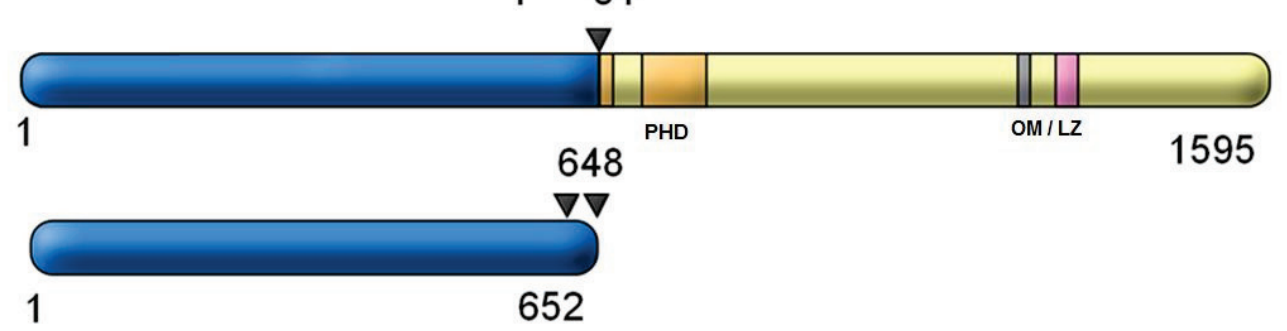

Figure 1. 2. t(10;11)(p12;q14) leading to fusion of CALM and AF10. (a) the translocation event, arrows indicating the approximate position of translocation and gene direction (b) the genes involved (CALM and AF10) and their fusion products as a consequence of $t(10 ; 11)(p 12 ; q 14)$. AF10 contains an octapeptide motif and leucine zipper domain (OM/LZ) and a plant homeo domain (PHD) finger. Small triangles indicate the different breaking points in AF10 and in CALM as observed in CALM/AF10 patients. Numbers stand for amino acid counts. 
In a recent report, (Caudell et al., 2007) showed that $40 \%$ to $50 \%$ of the F1 generation of transgenic mice that express CALM/AF10 under the control of the vav promoter developed acute leukemia at a median age of 12 months. The transgenic mice were generated by cloning CALM/AF10 into the HS21/45-vav vector that uses $5^{\prime}$ and $3^{\prime}$ vav regulatory elements to direct expression of cDNA inserts specifically in hematopoietic tissues. Caudell and co-workers also reported, based on real-time RT-PCR experiment, that Hoxa5, Hoxa7, Hoxa9, Hoxa10, and Meis1 were all up-regulated in hematopoietic tissues (bone marrow, spleen, and thymus) from clinically healthy CALM/AF10. These genes were also found to be up-regulated in Myeloid leukemias from CALM/AF10 mice, indicating that up-regulation of these genes occurs in myeloid as well as T-cell tumors associated with CALM/AF10 expression (Caudell et al., 2007). Hox genes encode a class of transcription factors called homeobox genes and are found in clusters named A, B, C, and D on four separate chromosomes. Expression of these proteins is spatially and temporally regulated during embryonic development, and they regulate gene expression, morphogenesis, and differentiation. They encode proteins that involved in the placement of hindbrain segments in the proper location along the anterior-posterior axis during development. Meis 1 (myeloid ecotropic viral integration site 1) is also a homeobox gene and encodes a protein belonging to the TALE ('three amino acid loop extension') family of homeodomain-containing proteins.

Caudell et al. (2007) assayed the genes Hoxa5, Hoxa7, Hoxa9, Hoxa10, and Meis1 based on the findings of a previous report on patient microarray study that compared CALM/AF10 $0^{+}$to CALMAF10- T-ALL (Dik et al., 2005). Dik and co-workers reported that their analysis showed the up-regulation of HOXA5, HOXA9, HOXA10 and BMI1 in 


\section{Introduction}

the CALM $/ \mathrm{AF} 10^{+}$cases, a finding that they validated by quantitative RT-PCR by comparing an independent group of T-ALL to mixed lineage leukemia-translocated acute leukemias (MLL-t AL). The over-expression of HOXA genes was associated with overexpression of its cofactor MEIS1 (myeloid ecotropic viral integration site homeobox 1) in CALM/AF10 ${ }^{+}$T-ALL, reaching levels of expression similar to those observed in MLL-t AL (Dik et al., 2005). Consequently, Dik et al. (2005) reported that CALM/AF $10^{+}$T-ALL and MLL-t AL share a specific $H O X A$ overexpression, indicating they activate common oncogenic pathways.

Furthermore, BMI1 (polycomb, ubiquitin ligase, B-lymphoma Mo-MLV integration site), a gene located close to AF10 breakpoint and controls cellular proliferation through suppression of the tumor suppressors encoded by the $C D K N 2 A$ locus, was found to be over-expressed only in CALM/AF10+ T-ALL and not in MLL-t AL (Dik et al., 2005). As $C D K N 2 A$ is often deleted in T-ALL and was found to be conserved in CALM/AF10+ T-ALL, Dik and co-workers suggested that decreased CDKN2A activity, as a result of BMI1 overexpression, contributes to leukemogenesis in CALM/AF10+ T-ALL.

Little is known about the molecular mechanism of leukemogenesis of CALM/AF10 (Caudell and Aplan, 2008). Recently, there has been a report that demonstrated that the H3K79 methyltransferase hDOT1L (DOT1-like, histone H3 methyltransferase ( $S$. cerevisiae)), a gene that mediates $\mathrm{H} 3 \mathrm{~K} 79$ methylation and is associated with telomere silencing, meiotic checkpoint control, and DNA damage response) contributes to MLLAF10-mediated leukemogenesis through its interaction with AF10 (Okada et al., 2005). The role of DOT1L in embryonic development, genome stability and heterochromatin formation has very recently been shown in a report where (Jones et al., 2008) analyzed 
mouse embryonic stem (ES) derived from DotlL mutant blastocysts and observed that these cells had global loss of H3K79 methylation as well as reduced levels of heterochromatic marks (H3K9 di-methylation and H4K20 tri-methylation) at their centromeres and telomeres. Jones and co-workers further noted that these changes are accompanied by aneuploidy, telomere elongation, and proliferation defects.

According to Okada et al. (2005), mistargeting of $h D O T I L$ to Hoxa9 plays an important role in MLL-AF10-mediated leukemogenesis and suggests that the enzymatic activity of hDOTIL may provide a potential target for therapeutic intervention. In another experiment where CALM/AF10 was knocked down in U937 cells using a vector-based RNA interference (RNAi) and later transplanted into NOD/SCID mice. The same group found that $h D O T 1 L$ contributes to CALM-AF10- mediated leukemic transformation by preventing nuclear export of CALM-AF10 and up-regulation of the Hoxa5 gene through H3K79 methylation (Okada et al., 2006). In contrast to the hypothesis put forward by Dik et al. (2005), Okada and co-workers demonstrated that CALM/AF10 fusion is both necessary and sufficient for leukemic transformation.

Even though much is known about the CALM/AF10 fusion from patient samples and the leukemic potential of CALM/AF10 is well established in mouse models, the mechanisms that are required for CALM/AF10-mediated leukemogenesis are still poorly understood. The aim of this study is to identify immediate target genes of CALM/AF10 using gene expression profiling on an Affymetrix microarray platform with an inducible CALM/AF10 cell line system. Identifying early and potentially direct targets of CALM/AF10 will increase our understanding of the molecular mechanism of CALM/AF10-mediated-leukemogenesis. 


\section{Materials and Methods}

\subsection{Materials}

\subsubsection{Chemicals}

Table 2.1. List of chemicals

\begin{tabular}{|c|c|c|c|c|}
\hline $\begin{array}{l}\text { Name of } \\
\text { Reagent }\end{array}$ & IUPAC Name & $\begin{array}{l}\text { Molecular } \\
\text { formula }\end{array}$ & $\begin{array}{l}\text { Molar } \\
\text { Mass } \\
\text { (g/mol) }\end{array}$ & Company \\
\hline Agarose & $\begin{array}{l}\text { (14)-3,6-anhydro- } \alpha-L- \\
\text { galactopyranosyl-(13)- } \beta-D- \\
\text { galactopyranan }\end{array}$ & & $\begin{array}{l}167.6 \pm 7.8 \\
\times 10^{3}\end{array}$ & $\begin{array}{l}\text { Carl Roth® } \\
\text { GmbH, } \\
\text { Germany }\end{array}$ \\
\hline Aprotinin & Aprotinin & $\mathrm{C}_{28} 4 \mathrm{H}_{432} \mathrm{~N}_{84} \mathrm{O}_{79} \mathrm{~S}_{7}$ & 6511.51 & $\begin{array}{l}\text { Sigma- } \\
\text { Aldrich®, } \\
\text { USA }\end{array}$ \\
\hline ATP & $\begin{array}{l}\text { 5-(6-aminopurin-9-yl) } \\
\text {-3,4-dihydroxy-oxolan-2-yl } \\
\text { methoxy-hydroxy-phosphoryl } \\
\text { oxy-hydroxy-phosphoryl } \\
\text { oxyphosphonic acid }\end{array}$ & $\mathrm{C}_{10} \mathrm{H}_{16} \mathrm{~N}_{5} \mathrm{O}_{13} \mathrm{P}_{3}$ & 507.181 & 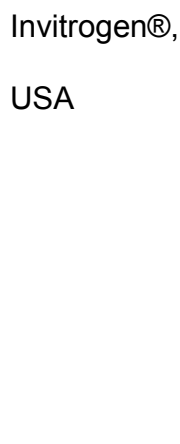 \\
\hline $\begin{array}{l}\text { Bromophenol } \\
\text { blue }\end{array}$ & $\begin{array}{l}\text { 2,6-dibromo-4-[3-(3,5-dibromo-4- } \\
\text { hydroxyphenyl)-1,1-dioxo-3- } \\
\text { benzo[c]oxathiolyl]phenol }\end{array}$ & $\mathrm{C}_{19} \mathrm{H}_{10} \mathrm{Br}_{4} \mathrm{O}_{5} \mathrm{~S}$ & 669.9607 & $\mathrm{NEB} \circledast$, USA \\
\hline Chloroform & Chloroform & $\mathrm{CHCl}_{3}$ & 119.38 & $\begin{array}{l}\text { Carl Roth® } \\
\text { GmbH, }\end{array}$ \\
\hline
\end{tabular}




\begin{tabular}{|c|c|c|c|c|}
\hline & & & & Germany \\
\hline dATP & Deoxyadenosine triphosphate & $\mathrm{C}_{10} \mathrm{H}_{16} \mathrm{~N}_{5} \mathrm{O}_{12} \mathrm{P}_{3}$ & 491.181623 & $\begin{array}{l}\text { Invitrogen }{ }^{\circledR} \text {, } \\
\text { USA }\end{array}$ \\
\hline dCTP & Deoxycytidine triphosphate & $\mathrm{C}_{9} \mathrm{H}_{16} \mathrm{~N}_{3} \mathrm{O}_{13} \mathrm{P}_{3}$ & 467.156923 & $\begin{array}{l}\text { Invitrogen }{ }^{\circledR}, \\
\text { USA }\end{array}$ \\
\hline DEPC & Diethylpyrocarbonate & $\mathrm{C}_{6} \mathrm{H}_{10} \mathrm{O}_{5}$ & 162.141 & $\begin{array}{l}\text { Invitrogen, } \\
\text { USA }\end{array}$ \\
\hline dGTP & Deoxyguanosine triphosphate & $\mathrm{C}_{10} \mathrm{H}_{16} \mathrm{~N}_{5} \mathrm{O}_{13} \mathrm{P}_{3}$ & 507.181023 & $\begin{array}{l}\text { Invitrogen }{ }^{\circledR}, \\
\text { USA }\end{array}$ \\
\hline DMSO & dimethyl sulfoxide & $\mathrm{C}_{2} \mathrm{H}_{6} \mathrm{OS}$ & 78.13 & $\begin{array}{l}\text { Carl Roth® } \\
\text { GmbH, } \\
\text { Germany }\end{array}$ \\
\hline DTT & 2S,3S)-1,4-Bis-sulfanylbutane-2,3-diol & $\mathrm{C}_{4} \mathrm{H}_{10} \mathrm{O}_{2} \mathrm{~S}_{2}$ & 154.26 & $\begin{array}{l}\text { Invitrogen } \AA \text {, } \\
\text { USA }\end{array}$ \\
\hline dTTP & Deoxythymidine-triphosphatase & & & $\begin{array}{l}\text { Invitrogen } \AA \text {, } \\
\text { USA }\end{array}$ \\
\hline EDTA & $\begin{array}{l}\text { 2-[2-(Bis (carboxymethyl) amino) } \\
\text { ethyl-(carboxymethyl) amino]acetic } \\
\text { acid }\end{array}$ & $\mathrm{C}_{10} \mathrm{H}_{16} \mathrm{~N}_{2} \mathrm{O}_{8}$ & 292.25 & $\begin{array}{l}\text { Carl Roth® } \\
\text { GmbH, } \\
\text { Germany }\end{array}$ \\
\hline Ethanol & Ethanol & $\mathrm{CH}_{3} \mathrm{CH}_{2} \mathrm{OH}$ & 46.06844 & $\begin{array}{l}\text { Carl Roth® } \\
\text { GmbH, } \\
\text { Germany }\end{array}$ \\
\hline
\end{tabular}




\section{Materials and Methods}

\begin{tabular}{|c|c|c|c|c|}
\hline $\begin{array}{l}\text { Ethidium } \\
\text { bromide }\end{array}$ & $\begin{array}{l}\text { 3,8-Diamino-5-ethyl-6- } \\
\text { phenylphenanthridinium bromide }\end{array}$ & $\mathrm{C}_{21} \mathrm{H}_{20} \mathrm{BrN}_{3}$ & 394.294 & $\begin{array}{l}\text { Invitrogen } \AA \text {, } \\
\text { USA }\end{array}$ \\
\hline Ficoll & & & & $\begin{array}{l}\text { Carl Roth }{ }^{\circ} \\
\text { GmbH, } \\
\text { Germany }\end{array}$ \\
\hline Glycerol & Propane-1,2,3-triol & $\mathrm{C}_{3} \mathrm{H}_{5}(\mathrm{OH})_{3}$ & 92.09382 & $\begin{array}{l}\text { Carl Roth }{ }^{\circ} \\
\text { GmbH, } \\
\text { Germany }\end{array}$ \\
\hline Isopropanol & Propan-2-ol & $\mathrm{C}_{3} \mathrm{H}_{8} \mathrm{O}$ & 60.10 & $\begin{array}{l}\text { Carl Roth }{ }^{\circ} \\
\text { GmbH, } \\
\text { Germany }\end{array}$ \\
\hline Leupeptin & $\begin{array}{l}\text { Ac-Leu-Leu-Arg-H; N-acetyl-L-leucyl- } \\
\text { L-leucyl-D,L-argininaldehyde }\end{array}$ & $\begin{array}{l}\text { Ac - Leu - Leu - } \\
\text { Arg - CHO }\end{array}$ & 426.6 & $\begin{array}{l}\text { Sigma- } \\
\text { Aldrich }{ }^{\circledR} \\
\text { USA }\end{array}$ \\
\hline $\begin{array}{l}\text { Magnesium } \\
\text { acetate }\end{array}$ & Magnes & $\left(\mathrm{CH}_{3} \mathrm{COO}\right)_{2} \mathrm{Mg}$ & 214.4 & $\begin{array}{l}\text { Carl Roth }{ }^{\circ} \\
\text { GmbH, } \\
\text { Germany }\end{array}$ \\
\hline $\begin{array}{l}\text { Magnesium } \\
\text { chloride }\end{array}$ & Magnesium chloride & $\mathrm{MgCl}_{2}$ & 95.211 & $\begin{array}{l}\text { Carl Roth }{ }^{\circ} \\
\text { GmbH, } \\
\text { Germany }\end{array}$ \\
\hline $\begin{array}{l}\text { Magnesium } \\
\text { sulphate }\end{array}$ & Magnesium sulphate & $\mathrm{MgSO}_{4}$ & 120.415 & $\begin{array}{l}\text { Carl Roth }{ }^{\circ} \\
\text { GmbH, } \\
\text { Germany }\end{array}$ \\
\hline
\end{tabular}


Materials and Methods

\begin{tabular}{|c|c|c|c|}
\hline Pefabloc & $\begin{array}{l}\text { 4-(2-Aminoethyl) benzenesulfonyl } \\
\text { fluoride hydrochloride }\end{array}$ & $\mathrm{C}_{8} \mathrm{H}_{10} \mathrm{FNO}_{2} \mathrm{~S}$ & 203.235 \\
\hline
\end{tabular}

USA

\begin{tabular}{|c|c|c|c|c|}
\hline PEG & poly(oxyethylene) & $\mathrm{C}_{2 \mathrm{n}+2} \mathrm{H}_{4 \mathrm{n}+6} \mathrm{O}_{\mathrm{n}+2}$ & $44 n+62$ & $\begin{array}{l}\text { Sigma- } \\
\text { Aldrich } \circledast \text {, } \\
\text { USA }\end{array}$ \\
\hline Pepstatin & $\begin{array}{l}\text { 3-hydroxy-4-[2-[3-hydroxy-6-methyl-4- } \\
\text { [3-methyl-2-[3-methyl-2-(3- } \\
\text { methylbutanoylamino)butanoyl]amino- } \\
\text { butanoyl]amino-heptanoyl]- } \\
\text { aminopropanoylamino]-6-methyl- } \\
\text { heptanoic acid }\end{array}$ & $\mathrm{C}_{34} \mathrm{H}_{63} \mathrm{~N}_{5} \mathrm{O}_{9}$ & 685.892 & $\begin{array}{l}\text { Sigma- } \\
\text { Aldrich } ®, \\
\text { USA }\end{array}$ \\
\hline $\begin{array}{l}\text { Potassium } \\
\text { acetate }\end{array}$ & Potassium acetate & $\mathrm{CH}_{3} \mathrm{COOK}$ & 98.15 & $\begin{array}{l}\text { Carl Roth }{ }^{8} \\
\text { GmbH, } \\
\text { Germany }\end{array}$ \\
\hline SDS & Sodium dodecyl sulfate & $\mathrm{NaC}_{12} \mathrm{H}_{25} \mathrm{SO}_{4}$ & 288.38 & $\begin{array}{l}\text { Carl Roth }{ }^{\circledR} \\
\text { GmbH, } \\
\text { Germany }\end{array}$ \\
\hline Sodium chloride & Sodium chloride & $\mathrm{NaCl}$ & 58.44277 & $\begin{array}{l}\text { Carl Roth® } \\
\text { GmbH, } \\
\text { Germany }\end{array}$ \\
\hline $\begin{array}{l}\text { Sodium } \\
\text { hydroxide }\end{array}$ & Sodium hydroxide & $\mathrm{NaOH}$ & 39.9971 & $\begin{array}{l}\text { Carl Roth }{ }^{\circledR} \\
\text { GmbH, } \\
\text { Germany }\end{array}$ \\
\hline
\end{tabular}




\section{Materials and Methods}

\begin{tabular}{|c|c|c|c|c|}
\hline Sucrose & Sucrose & $\mathrm{C}_{12} \mathrm{H}_{22} \mathrm{O}_{11}$ & 342.29648 & $\begin{array}{l}\text { Carl Roth }{ }^{\circledR} \\
\text { GmbH, } \\
\text { Germany }\end{array}$ \\
\hline Tris & $\begin{array}{l}\text { 2-Amino-2-hydroxymethyl-propane- } \\
\text { 1,3-diol }\end{array}$ & $\mathrm{C}_{4} \mathrm{H}_{11} \mathrm{NO}_{3}$ & 121.14 & $\begin{array}{l}\text { Carl Roth } \circledast \\
\text { GmbH, } \\
\text { Germany }\end{array}$ \\
\hline Tween 20 & $\begin{array}{l}\text { Polyoxyethylene (20) sorbitan } \\
\text { monolaurate }\end{array}$ & $\mathrm{C}_{58} \mathrm{H}_{114} \mathrm{O}_{26}$ & 1227.54 & $\begin{array}{l}\text { Carl Roth } ® \\
\text { GmbH, } \\
\text { Germany }\end{array}$ \\
\hline Xylene cyanol & Xylene cyanol & $\mathrm{C}_{25} \mathrm{H}_{27} \mathrm{~N}_{2} \mathrm{O}_{6} \mathrm{~S}_{2} \mathrm{Na}$ & 538.61 & $\begin{array}{l}\text { Carl Roth } \circledast \\
\text { GmbH, } \\
\text { Germany }\end{array}$ \\
\hline Zinc chloride & Zinc chloride & $\mathrm{ZnCl}_{2}$ & 136.315 & $\begin{array}{l}\text { Carl Roth }{ }^{\circledR} \\
\text { GmbH, } \\
\text { Germany }\end{array}$ \\
\hline $\begin{array}{l}\beta- \\
\text { mercaptoethanol }\end{array}$ & 2-Hydroxy-1-ethanethiol & $\mathrm{C}_{2} \mathrm{H}_{6} \mathrm{OS}$ & 78.13 & $\begin{array}{l}\text { Sigma- } \\
\text { Aldrich } ® \text {, } \\
\text { USA }\end{array}$ \\
\hline
\end{tabular}




\subsubsection{Enzymes}

Table 2.2. List of enzymes

\begin{tabular}{|c|c|c|c|}
\hline Name of Reagent & Purpose & Unit Definition & Company \\
\hline Benzonase & $\begin{array}{l}\text { Removal of nucleic acids } \\
\text { from protein samples }\end{array}$ & $\begin{array}{l}\text { Amount of enzyme required to } \\
\text { completely digest } 37 \mu \mathrm{g} \text { of DNA in } \\
30 \text { minutes under standard assay } \\
\text { conditions }\end{array}$ & $\begin{array}{l}\text { Sigma- } \\
\text { Aldrich } ®, \text { USA }\end{array}$ \\
\hline $\begin{array}{l}\text { Calf Intestine Alkaline } \\
\text { Phosphatase (CIAP) }\end{array}$ & $\begin{array}{l}\text { Dephosphorylation of } \\
\text { DNA ends }\end{array}$ & $\begin{array}{l}1 \text { unit hydrolyzes } 1 \mu \mathrm{mol} \text { of } \mathrm{p} \text { - } \\
\text { nitrophenyl phosphate in } 1 \text { minute } \\
\text { at } 37^{\circ} \mathrm{C}\end{array}$ & $\begin{array}{l}\text { Invitrogen®, } \\
\text { USA }\end{array}$ \\
\hline $\begin{array}{l}\text { Polynucloetide Kinase } \\
\text { (PNK) }\end{array}$ & $\begin{array}{l}\text { Catalyzes the transfer of } \\
\text { the terminal phosphate of } \\
\text { ATP to } 5 \text { ' hydroxyl } \\
\text { termini of polynucleotides } \\
\text { such as DNA and RNA, } \\
\text { oligonucleotides and } 3^{\prime} \\
\text { mononucleotides }\end{array}$ & $\begin{array}{l}\text { One unit is the amount of enzyme } \\
\text { required to incorporate } 1 \mathrm{nmol} \text { of } \\
\text { radiolabeled ATP into DNA } \\
\text { substrate in } 30 \mathrm{~min} \text { at } 37^{\circ} \mathrm{C} \text {. }\end{array}$ & $\begin{array}{l}\text { Usb } ® \text { (United } \\
\text { States } \\
\text { Biochemical), } \\
\text { USA }\end{array}$ \\
\hline Proteinase $\mathrm{K}$ & $\begin{array}{l}\text { Degradation or removal } \\
\text { of proteins from samples }\end{array}$ & $\begin{array}{l}1 \text { unit liberates folin-positive } \\
\text { amino acids and peptides } \\
\text { corresponding to } 1 \mu \mathrm{mol} \text { of } \\
\text { tyrosine in } 1 \text { minute at } 37^{\circ} \mathrm{C} \text { in a } \\
\text { total reaction volume of } 250 \mu \mathrm{l}(1)\end{array}$ & $\mathrm{NEB} \circledast$, USA \\
\hline RNase H & $\begin{array}{l}\text { specifically hydrolyzes } \\
\text { the phosphodiester } \\
\text { bonds of RNA which is }\end{array}$ & $\begin{array}{l}\text { One unit is defined as the amount } \\
\text { of enzyme that will hydrolyze } 1 \\
\text { nmol of the RNA in }[3 \mathrm{H}] \text {-labeled }\end{array}$ & $\begin{array}{l}\text { Invitrogen®, } \\
\text { USA }\end{array}$ \\
\hline
\end{tabular}




\section{Materials and Methods}

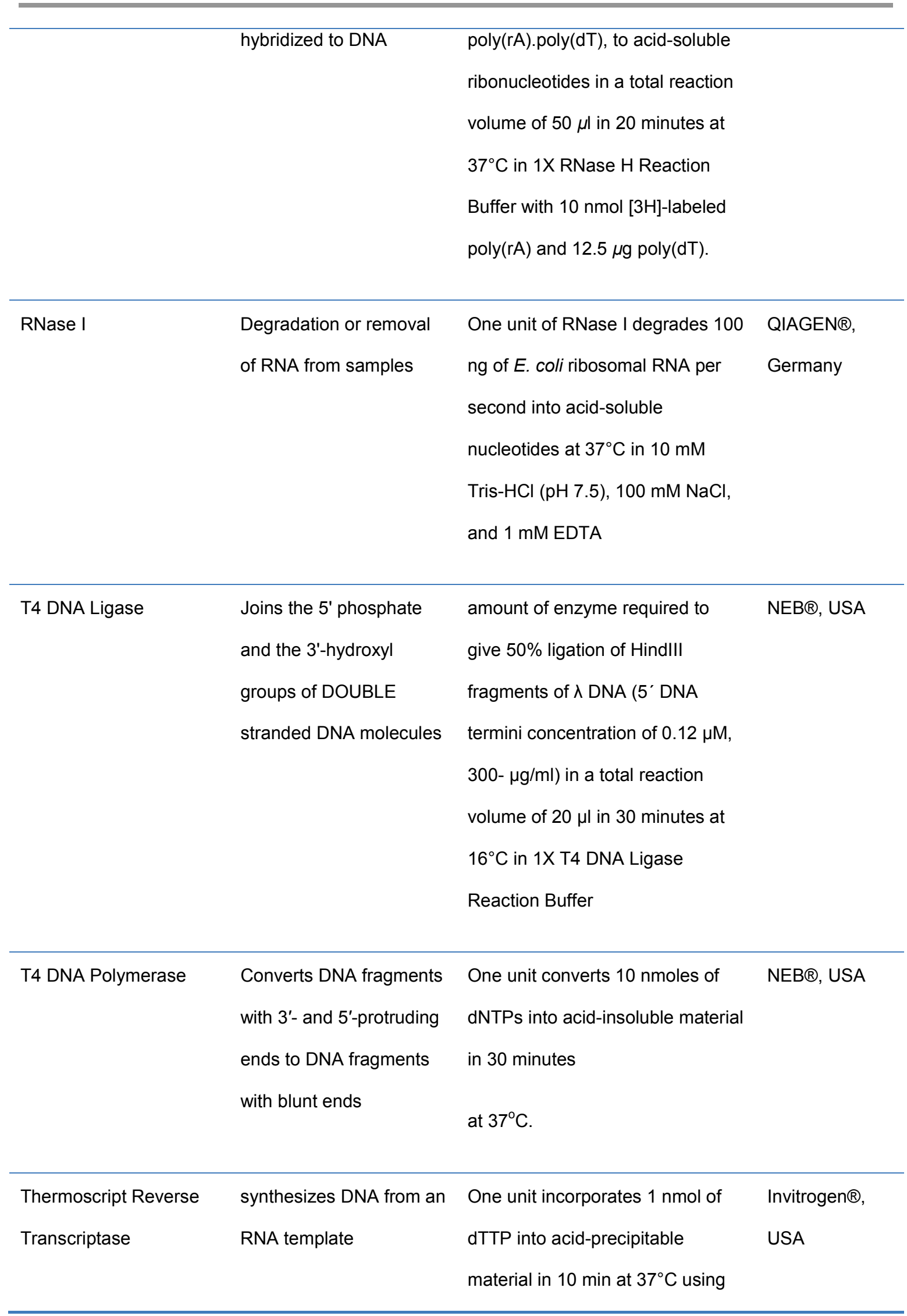




\subsubsection{Primers}

Table 2.3. List of Primers

\begin{tabular}{lll}
\hline \hline Name & Sequence & Purpose \\
\hline VP16TopNot & $5^{\prime}$-GATCGCGGCCGCCCTCCTGAAAGATGAAGCTA- & Amplify VP16 \\
& $3^{\prime}$ & transactivation \\
\hline VP16BottomXho & 5'-GATCTCGAGGCCGCGGATCCCGGACCCGG-3 & \\
\hline CALM2192for & d'-GCAATCTTGGCATCGGAAAT-3 & \\
\hline AF10254rev & P'-GCCTGTCGACATCCATGTTT-3 & Primer pairs \\
& & that amplify \\
& & the \\
& & CALM/AF10 \\
\hline
\end{tabular}

\subsubsection{Plasmids}

Table 2.4. List of Plasmids

\begin{tabular}{ll}
\hline \hline Name & Type \\
\hline pEYFP C1 & Mammalian expression vector \\
\hline pINCO NGFR & NGF expressing mammalian expression vector \\
\hline pRTS-1 & Mammalian expression vector \\
\hline pUC19 with Sfil cassette & \\
\hline
\end{tabular}




\section{Materials and Methods}

\subsubsection{Buffers and Solutions}

Table 2.5. List of Buffers and Solutions

\begin{tabular}{|c|c|c|}
\hline Name of Buffer/Solution & Purpose & Composition \\
\hline \multirow[t]{2}{*}{ Blocking Buffer } & Blocking protein membranes & $5 \mathrm{~g}$ Milk powder \\
\hline & & $0.1 \%$ Tween 20 in TBS \\
\hline \multirow[t]{4}{*}{ cDNA Synthesis Buffer } & Reverse transcriptase reaction Buffer & $250 \mathrm{mM}$ Tris acetate, $\mathrm{pH} 8.4$ \\
\hline & & $375 \mathrm{mM}$ potassium acetate \\
\hline & & $40 \mathrm{mM}$ magnesium acetate \\
\hline & & $20 \mu \mathrm{g} / \mathrm{ml} \mathrm{BSA}$ \\
\hline \multirow[t]{4}{*}{ CIAP dilution Buffer } & Dilution buffer for CIAP & 25mM Tris.Cl, pH 7.6 \\
\hline & & $1 \mathrm{mM} \mathrm{MgCl} 2$ \\
\hline & & $0.1 \mathrm{mM} \mathrm{ZnCl} 2$ \\
\hline & & $50 \%$ Glycerol (v/v) \\
\hline \multirow[t]{2}{*}{ Dephosphorylation Buffer } & Dephosphorylation Buffer & 50mM Tris. Cl, pH 8.5 \\
\hline & & $0.1 \mathrm{mM}$ EDTA \\
\hline EB Buffer & DNA elution buffer & $10 \mathrm{mM}$ Tris $\cdot \mathrm{Cl}, \mathrm{pH} 8.5$ \\
\hline ER & & Confidential \\
\hline Fetal Calf Serum (FCS) & Supplement to culture media & GIBCO $®$, USA \\
\hline FT LYSIS Buffer & Cell lysis for protein extraction & $600 \mathrm{mM} \mathrm{KCl} 20 \mathrm{mM}$ \\
\hline
\end{tabular}




\section{Materials and Methods}

Tris.Cl, pH 7.8

$20 \%$ Glycerol

\begin{tabular}{|c|c|c|}
\hline \multirow[t]{5}{*}{ Laemmli Buffer } & Protein sample preparation & $4 \%$ SDS \\
\hline & & $20 \%$ glycerol \\
\hline & & $10 \% \beta$-mercaptoethanol \\
\hline & & $0.004 \%$ bromphenol blue \\
\hline & & $0.125 \mathrm{M}$ Tris. Cl, $\mathrm{pH} 6.8$ \\
\hline \multirow[t]{6}{*}{ Ligation Buffer } & Buffer for ligation reaction & 132 mM Tris- $\mathrm{HCl}, \mathrm{pH} 7.6$ \\
\hline & & $20 \mathrm{mM} \mathrm{MgCl}_{2}$ \\
\hline & & $2 \mathrm{mM}$ dithiothreitol \\
\hline & & $2 \mathrm{mM}$ ATP \\
\hline & & $15 \%$ Polyethylene glycol \\
\hline & & (PEG 6000) \\
\hline \multirow[t]{4}{*}{ Loading dye } & Dye used for loading DNA and RNA & Bromophenol blue ( $0.25 \%)$ \\
\hline & samples on agarose gels & Xylene xyanol $(0.25 \%)$ \\
\hline & & Sucrose $(40 \%)$ \\
\hline & & $\mathrm{H}_{2} \mathrm{O}$ \\
\hline \multirow[t]{4}{*}{ Lysis Buffer } & Mammalian Genomic DNA extraction & $100 \mathrm{mM}$ Tris. Cl pH 8.5 \\
\hline & & $5 \mathrm{mM}$ EDTA \\
\hline & & $0.2 \%$ SDS \\
\hline & & $200 \mathrm{mM} \mathrm{NaCl}$ \\
\hline
\end{tabular}




\section{Materials and Methods}

$100 \mu \mathrm{g}$ Proteinase $\mathrm{K} / \mathrm{ml}$

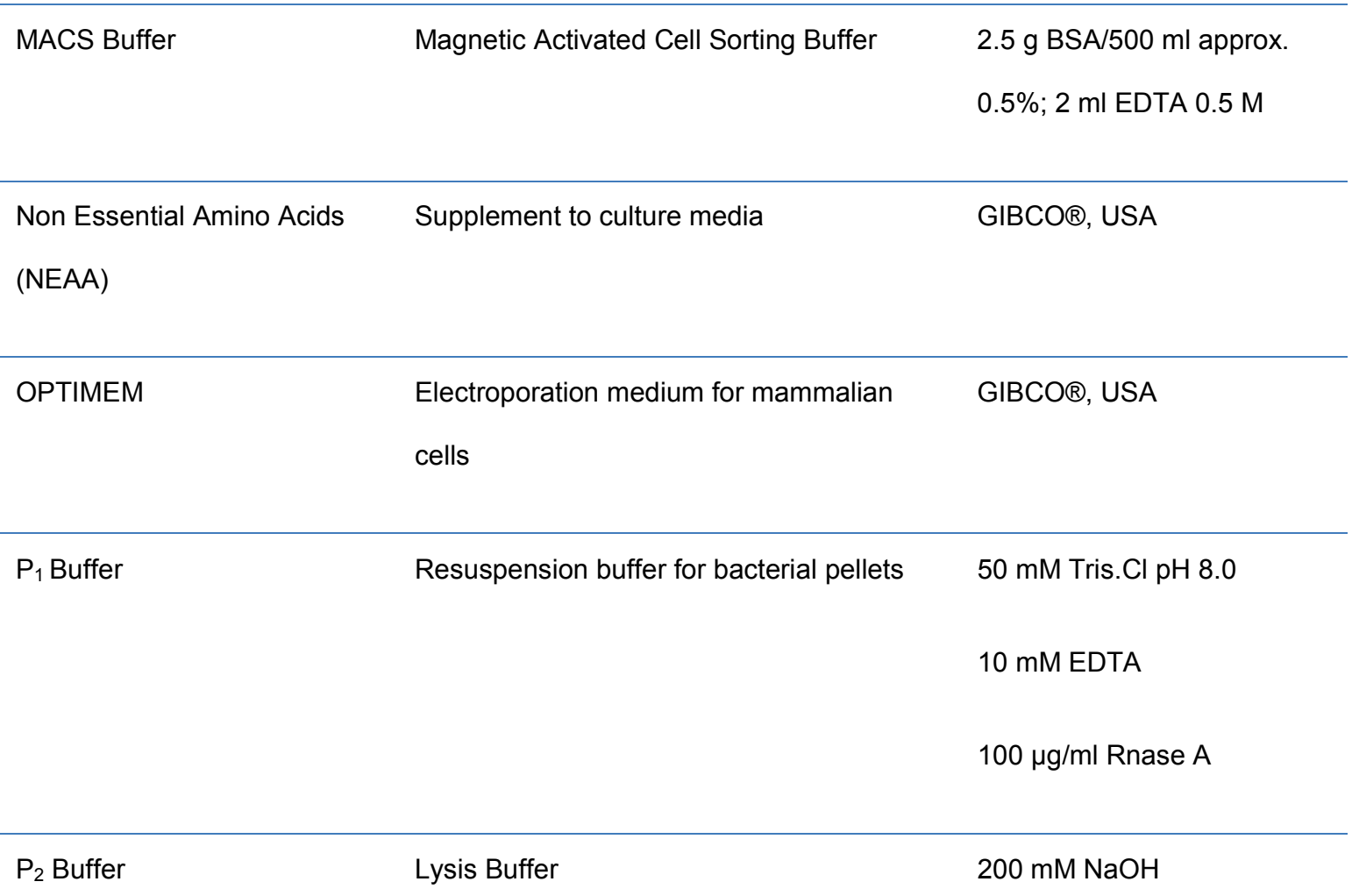

$1 \% \operatorname{SDS}(w / v)$

\begin{tabular}{ll}
\hline $\mathrm{P}_{3}$ Buffer & Neutralization Buffer \\
& $5.0 \mathrm{M}$ Potassium Acetate $\mathrm{pH}$
\end{tabular}

\begin{tabular}{lll}
\hline PBS & Phosphate Buffered Saline & GIBCO®, USA \\
\hline PCR Buffer & Traditional PCR Buffer & $500 \mathrm{mM} \mathrm{KCl}$
\end{tabular}

$100 \mathrm{mM}$ Tris. $\mathrm{Cl}, \mathrm{pH}$ 9.0,

$1.0 \%$ Triton $\times 100)$

Protein inhibitor cocktail Solution for freeze thaw protein exptraction $\quad 0.4 \mathrm{mg} / \mathrm{ml}$ Pefabloc procedure 
Materials and Methods

$10 \mu \mathrm{g} / \mathrm{ml}$ Leupeptin

$10 \mu \mathrm{g} / \mathrm{ml}$ Pepstatin

$5 \mu \mathrm{g} / \mathrm{ml}$ Aprotinin

\begin{tabular}{|c|c|c|}
\hline Pyruvic acid & Supplement to culture media & $\mathrm{GIBCO} \otimes$, USA \\
\hline \multirow[t]{4}{*}{ QBT Buffer } & Equilibration Buffer & $750 \mathrm{mM} \mathrm{NaCl}$ \\
\hline & & 50 mM MOPS, pH 7.0 \\
\hline & & 15\% Isopropanol (v/v) \\
\hline & & $0.15 \%$ Triton $^{\circledR} \mathrm{X}-100(\mathrm{v} / \mathrm{v})$ \\
\hline \multirow[t]{3}{*}{ QC Buffer } & Wash Buffer & $1.0 \mathrm{M} \mathrm{NaCl}$ \\
\hline & & 50 mM MOPS, pH 7.0 \\
\hline & & 15\% Isopropanol (v/v) \\
\hline QG Buffer & Gel solubilization buffer & Confidential \\
\hline \multirow[t]{3}{*}{ QN Buffer } & Elution Buffer & $1.6 \mathrm{M} \mathrm{NaCl}$ \\
\hline & & 50 mM MOPS, pH 7.0 \\
\hline & & 15\% Isopropanol (v/v) \\
\hline \multirow[t]{3}{*}{ T4 DNA Polymerase Buffer } & T4 DNA Polymerase Buffer & $330 \mathrm{mM}$ Tris-acetate, $\mathrm{pH} 7.8$ \\
\hline & & $660 \mathrm{mM}$ potassium acetate \\
\hline & & $100 \mathrm{mM}$ magnesium acetate \\
\hline
\end{tabular}




\section{Materials and Methods}

$5 \mathrm{mM}$ DTT

$\begin{array}{ll}\text { T4 PNK Buffer } & 0.5 \mathrm{M} \mathrm{Tris.Cl,} \mathrm{pH} \mathrm{7.6} \\ & 100 \mathrm{mM} \mathrm{MgCl}_{2} \\ & 100 \mathrm{mM} \beta \text {-mercaptoethanol }\end{array}$

TAE Buffer

Agarose electrophoresis Buffer

Tris base

Glacial acetic acid

EDTA, pH 8.0

TBE Buffer

Agarose electrophoresis Buffer

Tris base

Boric acid

EDTA, pH 8.0

TBS

Transfer Buffer for SDS-PAGE transfer

192mM Glycine

setup

25mM Tris

$20 \%$ Methanol

TE Buffer

Resuspension of air dried DNA

$10 \mathrm{mM}$ Tris. Cl pH 7.5

$0.1 \mathrm{mM}$ EDTA

\begin{tabular}{lll}
\hline TRIZOL $^{\circledR}$ & RNA extraction solution & $\begin{array}{l}\text { Guanidinium thiocyanate- } \\
\text { phenol-chloroform }\end{array}$ \\
\hline Trypan Blue & Counting cells & GIBCO ${ }^{\circ}$, Germany \\
\hline
\end{tabular}


2.1.6. Media

\subsubsection{Bacterial culture}

Table 2.6. Bacterial culture medium and agar

\begin{tabular}{lcc}
\hline \hline \multicolumn{1}{c}{ Name of Media } & Purpose & Company \\
\hline Liquid Broth (LB) Agar & Solid medium for bacteria culture & Carl Roth $\circledast \mathrm{GmbH}$, Germany \\
\hline Liquid Broth (LB) Medium & Liquid medium for bacteria culture & Carl Roth $\circledast \mathrm{GmbH}$, Germany \\
\hline
\end{tabular}

\subsubsection{Mammalian cell culture}

Table 2.7. Mammalian cell culture medium

\begin{tabular}{lll}
\hline \hline Name of Media & \multicolumn{1}{c}{ Purpose } & Company \\
\hline DMEM & Culture media for adherent & GIBCO $尺$, USA \\
& cells & \\
\hline RPMI 640 & Culture media for suspension & GIBCO $尺$, USA \\
& cells & \\
\hline
\end{tabular}




\section{Materials and Methods}

\subsubsection{Antibodies}

Table 2.8. List of Antibodies

\begin{tabular}{|c|c|c|}
\hline Name & Description & Company \\
\hline Anti AF10 & Recognizes the AF10 protein & $\begin{array}{l}\text { HelmholtzZentrum Muenchen, } \\
\text { Germany }\end{array}$ \\
\hline Anti CALM & $\begin{array}{l}\text { Recognizes the Clathrin } \\
\text { Assembly Lymphoid Myeloid } \\
\text { (CALM) protein }\end{array}$ & $\begin{array}{l}\text { Santa Cruz Biotechnology® Inc., } \\
\text { USA }\end{array}$ \\
\hline Anti FLAG & Detects the FLAG tag & Sigma-Aldrich $®$, USA \\
\hline Anti GFP & $\begin{array}{l}\text { Recognizes the Green } \\
\text { Fluorescent Protein (GFP) }\end{array}$ & Roche $®$, Switzerland \\
\hline Anti NGF & $\begin{array}{l}\text { Recognizes the cell membrane } \\
\text { protein NGF }\end{array}$ & Miltenyi®, Germany \\
\hline
\end{tabular}

2.1.8. Cells

\subsubsection{Bacterial Cells}

Table 2.9. List of chemo/electro-competent bacteria used for transformation

\begin{tabular}{|c|c|c|}
\hline Name & Description & Company \\
\hline $\mathrm{DH} 5 \alpha$ & $\begin{array}{l}\text { Chemically competent cells for } \\
\text { transformation purposes }\end{array}$ & Invitrogen $®$, Germany \\
\hline INV 110 & $\begin{array}{l}\text { Electrocompetent/chemically } \\
\text { competent bacterial cells that are } \\
\text { dam }^{-}\end{array}$ & Invitrogen $®$, Germany \\
\hline
\end{tabular}


Materials and Methods

XL1Blue Electrocompentent bacteria cells Invitrogen®, Germany

\subsubsection{Mammalian Cells}

Table 2.10. List of Mammalian cell lines used

\begin{tabular}{lll}
\hline \hline & Name & \\
& & Description \\
\hline $293 T$ & Human Embryonic Kidney cells & HelmholtzZentrum Muenchen, \\
& & Germany \\
\hline DG75 & HelmholtzZentrum Muenchen, \\
& & Germany \\
\hline H1299 & human lung cancer cell line & HelmholtzZentrum Muenchen, \\
& & Germany \\
\hline
\end{tabular}

\subsubsection{Computer Operating System and Application Software}

Table 2.11. List of software and applications

\begin{tabular}{|c|c|c|}
\hline Software & Purpose & Company/Source \\
\hline Adobe Photoshop CS2 & Image analysis application & Adobe $®$ Inc., USA \\
\hline dChip & Microarray analysis tool & Harvard (Li Wong), USA \\
\hline Endnote $\mathrm{X} 1$ & Reference manager application & Thompson $®$ Company, USA \\
\hline Gene Pattern 3.1.1 & Microarray analysis suite & Broad MIT, USA \\
\hline Image J 1.410 & Image analysis software & National Institute of Health, USA \\
\hline Linux Fedora Core 8 and 9 & Core Operating System & Open Source/Fedora Project \\
\hline Macromedia Freehand MX & $\begin{array}{l}\text { Drawing and image processing } \\
\text { application }\end{array}$ & Adobe $\circledast$ Inc., USA \\
\hline
\end{tabular}


Materials and Methods

\begin{tabular}{|c|c|c|}
\hline Microsoft Office 2007 & Office applications & Microsoft $\circledast$ Company, USA \\
\hline R Statistical Package $2.3-2.8$ & Freeware statistical package & CRAN, International \\
\hline SDS 2.1 & $\begin{array}{l}\text { Sequence Detection System for } \\
\text { Taqman Real Time PCR }\end{array}$ & Applied Biosystems ${ }^{\circledR}$, USA \\
\hline STATISTICA 7 & Multipurpose statistical software & Statsoft $®$ Inc., USA \\
\hline Vector NTI Suite 10 & $\begin{array}{l}\text { Molecular Biology and related } \\
\text { fields application Suite }\end{array}$ & Invitrogen $®$ Company, USA \\
\hline Windows Vista & Core Operating System & Microsoft $\circledast$ Company, USA \\
\hline Windows Xp & Core Operating System & Microsoft@ Company, USA \\
\hline
\end{tabular}

\subsubsection{Equipments and Utensils}

Table 2.12. List of equipments and utensils

\begin{tabular}{|c|c|c|}
\hline Name of Item & Purpose & Company \\
\hline $7900 \mathrm{HT}$ system Real Time PCR & Station for running Taqman $®$ & Applied Biosystems $®$, USA \\
\hline System & Real Time PCR reactions & \\
\hline Bacteria culture dish & Petri-dish for culturing bacteria & Corning Life Sciences, USA \\
\hline Mammalian cell culture dish & $\begin{array}{l}\text { Plates for growing mammalian } \\
\text { cells }\end{array}$ & Corning Life Sciences, USA \\
\hline Mammalian cell culture flask & $\begin{array}{l}\text { Flask for culturing mammalian } \\
\text { cells }\end{array}$ & Sarstedt $\circledast$, Germany \\
\hline Conical Flask & $\begin{array}{l}\text { Multipurpose plasticware for } \\
\text { routine lab activities }\end{array}$ & Falcon®, Germany \\
\hline EasyjecT Prima & Bacteria electroporation device & EquiBio ${ }^{\circ}$ Co., UK \\
\hline Graduated Cylinder & Measuring volumes & VIT-LAB尺 GmbH, Germany \\
\hline
\end{tabular}




\begin{tabular}{|c|c|c|}
\hline $\begin{array}{l}\text { High speed Centrifuge with } \\
\text { thermoregulator }\end{array}$ & $\begin{array}{l}\text { For cooled centrifugation } \\
\text { purposes } \\
\text { (max. centrifugation } 21160 \mathrm{rcf} \text { ) }\end{array}$ & Eppendorf®, USA \\
\hline $\begin{array}{l}\text { High volume Centrifuge with cooling } \\
\text { system }\end{array}$ & $\begin{array}{l}\text { For centrifugation of large } \\
\text { volumes (max speed } 4,500 \\
\text { rpm) }\end{array}$ & Sigma®, Germany \\
\hline Incubator Shaker & $\begin{array}{l}\text { For incubating samples at } \\
\text { specific temperature and } \\
\text { rotations, mainly bacterial } \\
\text { cultures }\end{array}$ & Innova ${ }^{\circledR}$, USA \\
\hline $\begin{array}{l}\text { Micro Fluidic Card Sample Block } \\
\text { (Also referred to as the thermal } \\
\text { cycler module or thermal block) }\end{array}$ & $\begin{array}{l}\text { Metal heating block required for } \\
\text { running low density array cards }\end{array}$ & Applied Biosystems $®$, USA \\
\hline Micro Fluidic Card Sealer & To seal LDA cards & Applied Biosystems $®$, USA \\
\hline Microfuge Tubes (1.5 ml) & $\begin{array}{l}\text { Multipurpose plastic tubes for } \\
\text { routine lab activities }\end{array}$ & Eppendorf $\circledast$, Germany \\
\hline Pipette tips & Plastic tips fitting to pipettes & Carl Roth ${ }^{\circledR} \mathrm{GmbH}$, Germany \\
\hline Micropipettes & $\begin{array}{l}\text { Tool for measuring, adding, } \\
\text { removing, and mixing small } \\
\text { volumes of solutions }\end{array}$ & Gilson® Co., USA \\
\hline $\begin{array}{l}\text { QIAfilter Cartridge with cap and } \\
\text { Plunger }\end{array}$ & $\begin{array}{l}\text { Filtration column during } \\
\text { maxiprep } \\
\text { (filters debries and proteins) }\end{array}$ & QIAGEN®, Germany \\
\hline QIAGEN-tip 500 & $\begin{array}{l}\text { Column for filtering and eluting } \\
\text { DNA }\end{array}$ & QIAGEN®, Germany \\
\hline
\end{tabular}




\section{Materials and Methods}

\begin{tabular}{lll}
\hline QIAquick column & Column for filtering solubilized & QIAGEN®, Germany \\
& agarose gel from DNA & \\
\hline Sorvall/Heraeus Custom Buckets & Centrifugation buckets for LDA & Thermo Fisher® Scientific, USA \\
and Adaptors (4 pcs.) & cards & \\
\hline Table-top Centrifuge & Routine centrifugation needs & Eppendorf $\circledast$, Germany \\
& (max. speed 14,000 rpm) & \\
&
\end{tabular}

\subsection{Methods}

\subsubsection{Extraction}

\subsubsection{Nucleic Acids Extraction}

\subsection{DNA Extraction}

\subsection{Mammalian Genomic DNA extraction}

This protocol was adopted from (Laird, 1991). Cells were grown in a 6 well plate (approximately $4 \times 10^{6}$ cells) were used as a starting material. The culture media was removed and cells were washed twice with PBS by centrifugation $\left(1100 \mathrm{rpm}\right.$ at $\left.4^{\circ} \mathrm{C}\right)$. Lysis buffer, which has been adjusted to allow enzymatic manipulation of the DNA without prior organic solvent extractions, was added to the washed cells. The procedure involved just three manipulations:

1. Addition of lysis buffer to the tissue or cells

2. Addition of isopropanol

3. Transfer of precipitate to TE

1. Lysis: The lysis buffer $(0.5 \mathrm{ml})$ was added to the cells. Digestion was complete within 4 hours at $37^{\circ} \mathrm{C}$ with agitation. 
2. Isopropanol precipitation: One volume of isopropanol was added to the lysate and the samples were mixed or swirled until precipitation was complete (viscosity completely gone).

3. Recovery of precipitate: The DNA was recovered by lifting the aggregated precipitate from the solution using a disposable yellow tip. Excess liquid was dabbed off and the DNA was dispersed in a pre-labeled Eppendorf tube containing, depending on the size of the precipitate, 20 to $500 \mu 1$ of TE Buffer. Complete dissolution of the DNA may require several hours of agitation at $37^{\circ} \mathrm{C}$. It is important that the DNA is completely dissolved to ensure the reproducible removal of aliquots for analysis.

\subsection{Plasmid DNA Extraction}

Miniprep

Approximately $1.5 \mathrm{ml}$ of a bacterial overnight culture was centrifuged at 11,000 rpm for approximately 1 minute. The supernatant was decanted and the pellet was resuspended with $300 \mu 1$ Buffer $\mathrm{P}_{1} .300 \mu 1 \mathrm{P}_{2}$ was immediately added and was the mix was left at room temperature for 5 minutes. Following the 5 minute incubation, $300 \mu 1 \mathrm{P}_{3}$ was added and samples were centrifuged at $14,000 \mathrm{rpm}$ for 10 minutes. $900 \mu \mathrm{l}$ of the supernatant was taken and transferred to a fresh tube. Plasmid DNA was precipitated by adding 0.7 of volume isopropanol. Tubes were kept at $-20^{\circ} \mathrm{C}$ for 10 minutes and were later centrifuged for 30 minutes at $4^{\circ} \mathrm{C}$. The supernatant was discarded and the pellet was washed with $70 \%$ Ethanol by centrifuging at $14,000 \mathrm{rpm}$ for 15 minutes. The supernatant was discarded and the pellet was dried at room temperature for 10 minutes. The pellet was resuspended with $20 \mu 1$ of $1 \mathrm{x}$ TE buffer and kept at $-20^{\circ} \mathrm{C}$ for future use. 


\section{Materials and Methods}

\section{Maxiprep}

The whole protocol has been adopted from QIAGEN EndoFree ${ }^{\circledR}$ Plasmid Purification Handbook (http://www1.qiagen.com/HB/CompactPrep_EN). A single bacterial colony was picked from a freshly streaked selective plate and a starter culture of $2-5 \mathrm{ml} \mathrm{LB}$ medium containing the appropriate selective antibiotic was inoculated. The starter culture was incubated overnight at $37^{\circ} \mathrm{C}$ with vigorous shaking (approx. $300 \mathrm{rpm}$ ). A tube or flask was used with a volume of at least 4 times the volume of the culture. The starter culture was diluted $1 / 500$ to $1 / 1000$ into selective LB medium. For high-copy plasmids, $100 \mathrm{ml}$ medium was inoculated with 100-200 $\mu$ l of starter culture. For low-copy plasmids, $250 \mathrm{ml}$ medium was inoculated with $250-500 \mu \mathrm{l}$ of starter culture. The culture was grown at $37^{\circ} \mathrm{C}$ for $12-16 \mathrm{~h}$ with vigorous shaking (approx. $300 \mathrm{rpm}$ ). A flask with a volume of at least 4 times the volume of the culture was used. The culture usually reaches a density of approximately $3-4 \times 10^{9}$ cells $/ \mathrm{ml}$, which typically corresponds to a pellet wet weight of approximately 3 g/liter medium. Bacterial cells were harvested by centrifugation at $6000 \times \mathrm{g}$ for $15 \mathrm{~min}$ at $4^{\circ} \mathrm{C}$. If there was a need to stop the procedure, cells were frozen at $-20^{\circ} \mathrm{C}$. The bacterial pellet was resuspended in $10 \mathrm{ml}$ Buffer P1. For efficient lysis it is important to use a vessel that is large enough to allow complete mixing of the lysis buffers. The pellet was resuspended completely by vortexing or pipetting up and down until no cell clumps remained. Following Resuspension, $10 \mathrm{ml}$ Buffer P2 was added and mixed thoroughly by vigorously inverting the sealed tube 4-6 times, and incubated at room temperature $\left(15-25^{\circ} \mathrm{C}\right)$ for $5 \mathrm{~min}$. During the incubation the QIAfilter Cartridge was prepared. $10 \mathrm{ml}$ pre-chilled Buffer P3 was added to the lysate and mixed immediately and thoroughly by vigorously inverting 4-6 times. Precipitation is enhanced by using chilled Buffer P3. The lysate was poured into the barrel of the QIAfilter 
Cartridge and incubated at room temperature $\left(15-25^{\circ} \mathrm{C}\right)$ for $10 \mathrm{~min}$. The cap was removed from the QIAfilter Cartridge outlet nozzle. The plunger was gently inserted into the QIAfilter Maxi Cartridge and the cell lysate was filtered into a $50 \mathrm{ml}$ tube. Approximately $25 \mathrm{ml}$ of the lysate is generally recovered after filtration. $2.5 \mathrm{ml}$ Buffer ER was added to the filtered lysate and was mixed by inverting the tube approximately 10 times and incubating on ice for $30 \mathrm{~min}$. QIAGEN-tip 500 was equilibrated by applying $10 \mathrm{ml}$ Buffer QBT and the column was allowed to empty by gravity flow. The filtered lysate was applied to the QIAGEN-tip and allowed to enter the resin by gravity flow. The QIAGEN-tip was washed with 2 x $30 \mathrm{ml}$ Buffer QC. Buffer QC was allowed to move through the QIAGEN-tip by gravity flow. DNA was eluted with $15 \mathrm{ml}$ Buffer QN. DNA was precipitated by adding $10.5 \mathrm{ml}$ (0.7 volumes) room-temperature isopropanol to the eluted DNA. The mix was centrifuged immediately at $\geq 15,000 \times \mathrm{g}$ for $30 \mathrm{~min}$ at $4^{\circ} \mathrm{C}$. The supernatant was carefully decanted. DNA pellet was washed with $5 \mathrm{ml}$ of endotoxinfree room-temperature $70 \%$ ethanol and centrifuged at $\geq 15,000 \times \mathrm{g}$ for 10 minutes. Again, the supernatant was carefully decanted without disturbing the pellet. The pellet was Air-dried for 5-10 min, and re-dissolved in a suitable volume of endotoxin-free Buffer TE.

\subsection{Organic precipitation of DNA}

This method is useful for precipitation of DNA from enzymatic reactions. 0.6 volume of isopropanol is added to the sample. After mixing the sample, 2 volumes of $95 \%$ cold ethanol were added and sample was placed at $-80^{\circ} \mathrm{C}$ for 30 minutes. Following the incubation, the sample was centrifuged at $12,000 \mathrm{rpm}$ at $4^{\circ} \mathrm{C}$ for 25 minutes. The supernatant was decanted and the pellet was drained by inverting the eppendorf tube. 2 


\section{Materials and Methods}

volumes of $80 \%$ room temperature ethanol were added to the sample and incubated at room temperature for 10 minutes. The sample was centrifuged for at $12,000 \mathrm{rpm}$ at $4^{\circ} \mathrm{C}$ for 7 minutes. The supernatant was decanted and pellet air dried for $5-10$ minutes at room temperature and resuspended in suitable volume of TE buffer or water.

\subsection{RNA Extraction}

Cells Grown in Suspension were pelleted by centrifugation. Cells were lysed in TRIZOL $^{\circledR}$ Reagent by repetitive pipetting. $1 \mathrm{ml}$ of TRIZOL $^{\circledR}$ reagent per $5-10 \times 10^{6}$ of cells was used. Washing cells before addition of TRIZOL ${ }^{\circledR}$ Reagent was avoided as this increases the possibility of mRNA degradation. Insoluble material was removed from the homogenate by centrifugation at $12,000 \times g$ for 10 minutes at 2 to $8^{\circ} \mathrm{C}$. The resulting pellet contains extracellular membranes, polysaccharides, and high molecular weight DNA, while the supernatant contains RNA. The cleared homogenate solution was transferred to a fresh tube. The homogenized samples were incubated for 5 minutes at 15 to $30^{\circ} \mathrm{C}$ to permit the complete dissociation of nucleoprotein complexes. $0.2 \mathrm{ml}$ chloroform per $1 \mathrm{ml}$ of TRIZOL ${ }^{\circledR}$ reagent was added. Tubes were shaken vigorously by hand for 15 seconds and incubated at 15 to $30^{\circ} \mathrm{C}$ for 2 to 3 minutes. The samples were centrifuged at no more than $12,000 \times g$ for 15 minutes at 2 to $8^{\circ} \mathrm{C}$. Following centrifugation, the mixture separates into a lower red, phenol-chloroform phase, an interphase, and a colorless upper aqueous phase. RNA remains exclusively in the aqueous phase. The volume of the aqueous phase is about $60 \%$ of the volume of TRIZOL ${ }^{\circledR}$ reagent used for homogenization. Transfer the aqueous phase to a fresh tube, and save the organic phase if isolation of DNA or protein is desired. RNA was precipitated from the aqueous phase by mixing with isopropanol. $0.5 \mathrm{ml}$ of isopropanol per $1 \mathrm{ml}$ of TRIZOL $^{\circledR}$ 
Reagent used for the initial homogenization was used. Samples were incubated at 15 to $30^{\circ} \mathrm{C}$ for 10 minutes and centrifuged at $12,000 \times g$ for 10 minutes at 2 to $8^{\circ} \mathrm{C}$. The RNA precipitate forms a gel-like pellet on the side and bottom of the tube. The supernatant was removed. The RNA pellet was washed once with $75 \%$ ethanol, adding at least $1 \mathrm{ml}$ of $75 \%$ ethanol per $1 \mathrm{ml}$ of TRIZOL ${ }^{\circledR}$ Reagent used for the initial homogenization. The sample was mixed by vortexing and centrifuged at $7,500 \times g$ for 5 minutes at 2 to $8^{\circ} \mathrm{C}$. The RNA pellet was air-dried for 5 minutes and was dissolved in RNase-free water by passing the solution a few times through a pipette tip, and incubating for 10 minutes at 55 to $60^{\circ} \mathrm{C}$.

\subsection{Protein Extraction}

\subsection{Freeze thaw method}

The culture medium was removed from the cells, and the cells werer washed in ice-cold PBS. The sample was transferred to $1.5 \mathrm{ml}$ microfuge tube. Cells were pelleted at top speed in a microfuge (45s in cold-room). The pellet was resuspended in FT LYSIS Buffer (25-40 $\mu 1$ per confluent $6 \mathrm{~cm}$ dish, 50-80 $\mu 1$ per confluent $10 \mathrm{~cm}$ dish). The tubes were dropped into liquid nitrogen for shock-freezeing. The samples were taken out of the liquid nitrogen (once they are frozen) and thawed on ice and were vortexed briefly. The freeze-thaw cycle was repeated two more times. Finally, $250 \mathrm{U}$ of Benzonase was added to the samples to digest DNA and incubated at room temperature for 10 minutes. Protein concentration was measured by Bradford method. Equal volume of 2xLaemmli Buffer was added prior to analysis by SDSPAGE and heated at $95^{\circ} \mathrm{C}$ for 10 minutes. Samples were loaded on the gel immediately (Note that these samples must be loaded while still 


\section{Materials and Methods}

warm, because the salt in the FT Buffer will cause the SDS in the Laemmli buffer to precipitate when cold).

\subsection{RIPA lysis method}

Cells were spun at $1000 \mathrm{rpm}$ for 10 minutes at $4^{\circ} \mathrm{C}$. The supernatant was removed and pellet was resuspended with cold PBS (approximately $1 \mathrm{ml}$ per $10 \mathrm{~cm} \mathrm{dish).} \mathrm{Cells} \mathrm{were}$ further centrifuged using the same settings and washed once more with cold PBS. The supernatant was removed and pellet was resuspended with $80 \mu$ l RIPA Buffer with protein inhibitors. The samples were gently mixed in a radial rotor at $15 \mathrm{rpm}$ for 30 minutes at $4^{\circ} \mathrm{C}$. Following the incubation, the samples were centrifuged for 10 minutes at $14,000 \mathrm{rpm}$ at $4^{\circ} \mathrm{C}$. Supernatant was collected in new tubes and the protein amount was quantified using the Bradford method.

\subsubsection{DNA digestions and modifications}

\subsubsection{Restriction Endonuclease digestion}

DNA restriction endonuclease digestion is usually carried out with a 2-fold to 10 -fold excess of restriction enzyme in the total volume of $20 \mu \mathrm{l}$ using $0.2-1.5 \mu \mathrm{g}$ of DNA. A typical restriction enzyme digestion protocol is presented below. The components were added in the following order for a $20 \mu 1$ reaction:

Table 2.13. Typical reaction mix setup for restriction digestion.

\begin{tabular}{lc}
\hline \hline Component & Volume \\
\hline Water, nuclease-free & $16 \mu \mathrm{l}$ \\
\hline 10X recommended buffer for restriction enzyme & $2 \mu \mathrm{l}$ \\
\hline Substrate DNA & $1 \mu \mathrm{l}(\sim 1 \mu \mathrm{g})$ \\
\hline 40 & \\
\hline
\end{tabular}


Samples were mixed gently and spun down briefly. Incubation was carried out at the optimum temperature for 1-16 hours. The digestion reaction may be scaled up or down.

\subsubsection{Dephosphorylation}

The following protocol was adapted from Invitrogen with some modifications. It was used to dephosphorylate vector backbones digested with one restriction enzyme that were subsequently used in cloning experiments.

The mass of DNA required for 1 pmol 5 end was determined by applying the following relations:

pmol ends $=$ pmol DNA $\times[($ number of cuts $\times 2)+2]$

$1 \mu \mathrm{g}$ of $1000 \mathrm{bp}$ DNA $=3.04$ pmol ends

Once the required amount of DNA was determined (amount of DNA having the required 1pmol of DNA ends), the following components were added to a microfuge tube:

$4 \mu 1$ of 10X dephosphorylation Buffer

1 pmol of DNA ends

Distilled water to $39 \mu 1$

The calf intestinal phosphatase (CIAP) was diluted in Dilution Buffer such that $1 \mu 1$ contains the amount of enzyme required for the appropriateefid (i.e. 1 unit for $5^{\prime}$ recessed and blunt ends and 0.01 units for 'aoßjerhang). For 5' -recessed and bluntended DNA, samples were incubated at $50^{\circ} \mathrm{C}$ for 60 minutes and samples with 5 


\section{Materials and Methods}

overhang were incubated at $37^{\circ} \mathrm{C}$ for 30 minutes. Samples were later run on Agarose gel and extracted or precipitated by organic extraction.

Occasionally, a simplified protocol was also employed. This protocol allows for the dephosphorylation of DNA directly in restriction endonuclease buffer in the presence of the restriction endonuclease by adding 1 unit of CIAP and incubating samples at $50^{\circ} \mathrm{C}$ for 5 minutes blunt-ended DNA and $37^{\circ} \mathrm{C}$ for 5 minutes for DNA with $5^{\prime}$ overhang.

\subsubsection{Phosphorylation}

This protocol is written for $10 \mathrm{pmol}$ of oligonucleotide. It can be scaled up or down accordingly. The oligonucleotide can be in any volume up to $25 \mu \mathrm{l}$ of water or buffer, $\mathrm{pH}$ 7.6.

The reaction mixture was as follows:

Table 2.14. Phosphorylation reaction mix

\begin{tabular}{lc}
\hline \hline Component & Volume \\
\hline Oligonucleotide $(10 \mathrm{pmol})$ & $\mu \mathrm{l}$ \\
\hline ATP & $\mu l$ \\
\hline T4 Polynucleotide Kinase (PNK) buffer (10X) & $5 \mu l$ \\
\hline T4 Polynucleotide Kinase (PNK) (diluted) & $2-5$ units \\
\hline Water & $-\mu l$ \\
\hline Total & $50 \mu l$ \\
\hline
\end{tabular}


The contents were mixed well and centrifuged briefly. Incubate was carried out at $37^{\circ} \mathrm{C}$ for 30 minutes and reaction was terminated by heating at $65^{\circ} \mathrm{C}$ for 10 minutes or adding EDTA to $5 \mathrm{mM}$.

\subsubsection{Blunting}

This protocol allows the conversion of DNA fragments with 3'- and 5'-protruding ends to DNA fragments with blunt ends. Conversion of the two types of protruding ends can be accomplished simultaneously by the $3^{\prime}->5^{\prime}$ exonuclease and $5^{\prime}->3^{\prime}$ polymerase activities of the T4 DNA Polymerase.

The reaction mix was:

Table 2.15. Reaction mix for blunting procedure

\begin{tabular}{ll}
\hline \hline Component & Volume \\
\hline DNA fragment (with protruding ends) & $>0.1 \mathrm{pmol}$ \\
\hline $10 X$ Buffer & $1 \mu \mathrm{l}$ \\
\hline Distilled sterile water & up to $9 \mu \mathrm{l}$ \\
\hline Total Volume & $9 \mu \mathrm{l}$ \\
\hline
\end{tabular}

Samples were incubated at $70^{\circ} \mathrm{C}$ for 5 minutes. $1 \mu 1$ of T4 DNA Polymerase was added and mixed gently by pipetting. Incubation was carried out at $37^{\circ} \mathrm{C}$ for 5 minutes. For DNA samples with low $\mathrm{G}+\mathrm{C}$ content, incubation was done $25^{\circ} \mathrm{C}$ instead of $37^{\circ} \mathrm{C}$. DNA Dilution Buffer was added to bring the DNA concentration to $1 \mu \mathrm{g} / 50 \mu 1$ and mixed thoroughly. Samples were later placed on ice to ensure deactivation of T4 DNA 


\section{Materials and Methods}

Polymerase. If the solution was to be stored, DNA extraction was done immediately by organic extraction.

\subsubsection{Ligation}

Ligation experiments are usually carried out in 3:1 proportion of insert to vector backbone ratio. The required amount of insert is calculated by using the following formula:

$$
\mathrm{I}_{a}=\frac{\mathrm{V}_{a} \times \mathrm{I}_{s}}{\mathrm{~V}_{s}} \times \frac{3}{1}
$$

Where $\mathrm{I}_{a}$ is the concentration of insert required, $\mathrm{V}_{a}$ is the amount of vector to be used, and $\mathrm{I}_{s}$ and $\mathrm{V}_{s}$ are insert size and vector size in base pairs, respectively. Reaction mix was:

Table 2.16. Ligation reaction setup

\begin{tabular}{llll}
\hline \hline Component & Main reaction & $\begin{array}{l}\text { Control 1 (no } \\
\text { insert) }\end{array}$ & $\begin{array}{c}\text { Control 2 (no } \\
\text { vector) }\end{array}$ \\
\hline Vector backbone & $-\mu \mathrm{l}$ & $-\mu \mathrm{l}$ \\
\hline Insert & $-\mu \mathrm{l}$ & $\mathrm{x}$ & $1 \mu \mathrm{l}$ \\
\hline T4 DNA Ligase & $1 \mu \mathrm{l}$ & $1 \mu \mathrm{l}$ & $2 \mu \mathrm{l}$ \\
\hline Ligation Buffer & $2 \mu \mathrm{l}$ & $2 \mu \mathrm{l}$ & to $20 \mu \mathrm{l}$ \\
\hline Nuclease Free Water & to $20 \mu \mathrm{l}$ & to $20 \mu \mathrm{l}$ & \\
\hline
\end{tabular}

For blunt-end ligation PEG (up to $15 \%$ ) was added to increase the efficiency.

Incubation was carried out according to the guidelines below: 
- Sticky end ligation reactions at room temperature for $1-2$ hours (or at $4^{\circ} \mathrm{C}$ in an ice-water mix that slowly thaws to room temperature overnight).

- Blunt-end ligation reactions at $4^{\circ} \mathrm{C}$ in an ice-water mix that slowly thaws to room temperature overnight.

\subsubsection{Transformation}

\subsubsection{Preparation of electro-competent bacteria Cells}

$500 \mathrm{ml}$ LB Medium was inoculated with a starter (a single bacterial colony that had been cultured in $3 \mathrm{ml} \mathrm{LB}$ medium overnight) culture and was mixed well. $\mathrm{OD}_{600}$ measurement was carried out every $45 \mathrm{~min}$. Once the $\mathrm{OD}_{600}$ reading was in the range $0.40-0.60$, the flask was taken out of the shaker and put in an ice-water bath for $15 \mathrm{~min}$. The culture was then distributed in $8(50 \mathrm{ml}$ each) conical bottom Falcon tubes and cells were pelleted at $4500 \mathrm{x}$ g for $5 \mathrm{~min}$ at $4^{\circ} \mathrm{C}$. The supernatant was discarded and cells were resuspended in $40 \mathrm{ml}$ ice cold water by pooling pellet from all tubes into one tube and subsequently centrifuged at $4500 \mathrm{xg}$ for $5 \mathrm{~min}$ at $4{ }^{\circ} \mathrm{C}$. Supernatant was again discarded and cells were resuspended in $40 \mathrm{ml}$ ice cold water. Further centrifugation was carried out at $4500 \mathrm{x} \mathrm{g}$ for $5 \mathrm{~min}$ at $4{ }^{\circ} \mathrm{C}$. After discarding the supernatant, cells were washed in $40 \mathrm{ml} 10 \%$ glycerol (prepared my mixing with ice cold water) and centrifuged at $4500 \mathrm{x} \mathrm{g}$ for $5 \mathrm{~min}$ at $4{ }^{\circ} \mathrm{C}$. Supernatant was discarded and the pellet was resuspended again in $40 \mathrm{ml} 10 \%$ glycerol and centrifuged at $4500 \mathrm{x} \mathrm{g}$ for $5 \mathrm{~min}$ at $4{ }^{\circ} \mathrm{C}$. Finally, $50 \mu 1$ aliquots were prepared in $1.5 \mathrm{ml}$ eppendorf tubes. The aliquots were immediately frozen in liquid nitrogen and later stored at $-80^{\circ} \mathrm{C}$. 


\section{Materials and Methods}

\subsubsection{Electroporation}

Electroporation is a procedure by which foreign DNA is introduced into cells by electrical pulse. The concise protocol is as follows. Frozen electro-competent bacterial cells were thawed on ice and mixed with the required amount of DNA, usually higher than $20 \mathrm{ng}$, and incubated further on ice for 1 minute. The mix was pipetted into electroporation cuvette and put on EasyjecT Prima electroporation device. The sample was pulsed with high voltage (1800-2500 volts) which lasts for few seconds. After a signal that the pulse was successful, sample was resuspended in $1 \mathrm{ml}$ antibiotic free room temperature LB medium and incubated for approximately 45 minutes at $37^{\circ} \mathrm{C}$ in an incubator with a shaker set to $220 \mathrm{rpm}$. Sample was later plated on an LB agar plate with the appropriate antibiotic selection.

\subsubsection{Electrophoresis}

\subsubsection{DNA electrophoresis}

DNA electrophoresis is a technique by which DNA fragments are separated by application of electric current by letting the fragments move through a matrix. The separation, as DNA is negatively charged, is based on size whereby larger fragments move slower and are more cathodal while smaller fragments move faster and are anodal. There are two buffer systems employed for standard DNA electrophoresis procedures: Tris Acetate EDTA (TAE) and Tris Borate EDTA (TBE). Tris-borate buffer (TBE) was advantageous for obtaining a higher resolution of smaller DNA fragments on agarose gels, when compared to the conventional tris-acetate buffer (TAE)(Yutaka MIURA, 1999). Critical DNA sizes and gel concentrations for a clear separation were about 2-kb for the $0.8 \%$ agarose and 300 -bp for the $2.0 \%$ agarose. DNA fragments larger than the 
critical size $(>2-\mathrm{kb}$ on $0.8 \%$ agarose gel) migrate faster in TAE, and the smaller fragments $(<300$-bp on $2 \%$ agarose gel) migrate faster in TBE showing the better resolution in a mini chamber system. Routine preparations were $0.8-1 \%$ agarose, which were prepared by mixing $400-500 \mathrm{mg}$ agarose with $50 \mathrm{ml} 0.5 \mathrm{x}$ or $1 \mathrm{x}$ TAE/TBE. $3 \mu \mathrm{l}$ from $10 \mathrm{mg} / \mathrm{ml}$ Ethidium bromide was added after the temperature of the gel was below $55^{\circ} \mathrm{C}$. The gel was left to solidify at room temperature for 15 to 20 minutes. Samples to be loaded were mixed with Loading dye (1x final concentration) and loaded on the gel after submerging the gel in the same buffer used for preparing it. Runs usually took 45 to 90 minutes at 90 Volts, depending on the size of DNA size to be analyzed.

\subsubsection{RNA electrophoresis}

Gel preparation for whole RNA electrophoresis was $1.2 \%$ agarose in $0.5 x$ TBE. Samples were mixed with loading dye ( $1 \mathrm{x}$ final concentration) and loaded on the gel. Electrophoresis was conducted at 90 Volts for 60 minutes.

\subsubsection{Gel Purification}

This protocol, adapted from QIAGEN® QIAquick Gel Extraction Kit Protocol, is designed to extract and purify DNA from standard or low-melt agarose gels in TAE or TBE buffer. Up to $400 \mathrm{mg}$ agarose can be processed per spin column. This kit can also be used for DNA cleanup from enzymatic reactions.

DNA fragment was excised from the agarose gel with a clean, sharp scalpel. Gel slice was weighed in a colorless tube. 3 volumes of Buffer QG were added to 1 volume of gel (100 mg $100 \mu \mathrm{l})$. The maximum amount of gel slice per QIAquick column is $400 \mathrm{mg}$. Sample was incubated at $50^{\circ} \mathrm{C}$ for $10 \mathrm{~min}$. To help dissolve gel, sample was mixed by vortexing the tube every $2-3$ min during the incubation. 1 gel volume of isopropanol was 


\section{Materials and Methods}

added to the sample and mixed thoroughly. To bind DNA, the sample was applied to the QIAquick column, and centrifuged for $1 \mathrm{~min}$ at 13,000 rpm. Flow-through was discarded and QIAquick column was placed back in the same collection tube. $0.75 \mathrm{ml}$ of Buffer PE was added to QIAquick column and centrifuged for $1 \mathrm{~min}$ at 13,000 rpm. The column was left to stand 2-5 min after addition of Buffer PE before centrifuging. Flow-through was again discarded and the QIAquick column was centrifuged for an additional $1 \mathrm{~min}$ at 17,900 x g (13,000 rpm). QIAquick column was placed into a clean $1.5 \mathrm{ml}$ microcentrifuge tube. To elute DNA, $30 \mu \mathrm{l}$ of Buffer EB (10 mM Tris $\cdot \mathrm{Cl}, \mathrm{pH} 8.5)$ or water ( $\mathrm{pH} 7.0-8.5)$ was added to the center of the QIAquick column membrane and was left to stand for 1 minute before centrifuging it for 1 minute.

\subsubsection{Cell Culture}

The following protocols have been adapted, with some modifications, from Sigma Aldrich $^{\circledR}$ cell culture handbook and SAFC ${ }^{\circledR}$ biosciences general cell culture techniques manual.

\subsubsection{Serum Preparation}

Animal serum is an excellent natural source of nutrients for cells in culture because it contains proteins, lipids, salts, vitamins, minerals, amino acids and other components necessary for growth. When stored and handled correctly, the performance characteristics of serum can be maintained for many years. Serum was stored frozen $\left(-10\right.$ to $\left.-40{ }^{\circ} \mathrm{C}\right)$ and protected from light.

\subsection{Thawing Procedure}

The serum bottle was taken out from the freezer and allowed to acclimate to room temperature for approximately 10 minutes. The container was placed in a $30-37^{\circ} \mathrm{C}$ water 
bath or incubator and swirled every $10-15$ minutes until the serum was completely thawed.

\subsection{Heat Inactivating Serum}

Heat inactivation of serum, which degrades complement proteins by raising the temperature of the serum to $56{ }^{\circ} \mathrm{C}$ for 30 minutes, is a required step before the serum could be used. To achieve this, thawed serum bottles were put in a water bath and were periodically agitated. The serum bottles were removed after 30 minutes at $56{ }^{\circ} \mathrm{C}$. The serum was aliquoted in $50 \mathrm{ml}$ falcon tubes and was allowed to cool before using it on cells. Unused portions were refrozen for later use.

\subsubsection{Media preparation}

RPMI640 was used for culturing suspension cells, DG75. The medium was supplemented with $10 \%$ Calf Feotal Serum (CFS), 1\% NEAA and 1\% Pyruvic acid. Complete medium was stored at $4^{\circ} \mathrm{C}$ until further use.

\subsubsection{Growing cells}

The following protocol has been adapted, with some modifications, from Sigma Aldrich ${ }^{\circledR}$ cell culture handbook.

DG-75 Cells are round to polygonal, single or clustered cells in suspension (pre-warmed $90 \%$ RPMI $1640+10 \%$ FBS). They are maintained at $0.1-0.5 \times 106$ cells $/ \mathrm{ml}$ and subcultured $1: 5$ to $1: 10$ every $24-48$ hours. The doubling time is $40-50$ hours and saturation density is $0.75-1.0 \times 106$ cells/ml (DSMZ, 2008).

Suspension cells Flasks (T25, T75 and T175) were used to culture the cells. Cultures were viewed using an inverted phase contrast microscope. Cells growing in exponential 


\section{Materials and Methods}

growth phase are bright, round and refractive. Occasionally, cells were very sticky and required a gentle knock to the flask to detach them. Overgrowth of cells was monitored by checking the change in $\mathrm{pH}$ of the medium, indicated by change in color of the phenol in the medium from red to yellow. For sub-culturing, the cells were allowed to settle to the bottom of the flask for $10-20$ minutes. Once they have settled, the supernatant was removed by leaving a thin layer of cells at the bottom of the flask. Desired number of cells (after calculating cells $/ \mathrm{ml}$ ) was re-seeded into freshly prepared flasks without centrifugation just by diluting the cells. This was repeated every 2-3 days.

\subsubsection{Counting cells}

Trypan blue is the stain most commonly used to distinguish viable from nonviable cells. Viable cells exclude the dye, while nonviable cells absorb the dye and appear blue when viewed with a microscope. Cells should be in suspension as single cells in medium or a buffered saline before counting. Trypan blue has a higher affinity for serum protein than for cellular protein, so suspending cells in medium containing serum generates a dark background.

Trypan blue was first diluted with Phosphate Buffered Saline (PBS) to a working concentration of $0.02 \%-0.04 \%$. Cells were prepared in duplicate for counting in 1:100 dilutions in trypan blue solution. After being stained with trypan blue, the cells were counted within three minutes to avoid staining of viable cells as they will begin to take up the dye. A small amount of the stained cell suspension was placed onto the slot of a clean hemacytometer with coverslip. The cell suspension passed under the coverslip by capillary action. The opposite chamber was filled with the second diluted sample. The 
hemacytometer was placed on the stage of an inverted microscope and the focus and power was adjusted until a single counting square fills the field. If the counts differed by more than $20 \%$, a third sample was prepared to verify the count. The viable cell number was calculated using the formula:

$$
\text { Viable Cell Number/ml }=\frac{\text { Number of viable cells Counted }}{\text { Number of Squares Counted }} \times 10^{4} \times \text { Dilution Factor }
$$

\subsubsection{Freezing cells}

Cryopreservation is an efficient method by which cells are stored in liquid nitrogen ($196^{\circ} \mathrm{C}$ ) without significantly losing their viability. The following procedure describes a quick method by which cells can be frozen.

Freezing medium was prepared by mixing $90 \%$ fetal calf serum and $10 \%$ dimethyl sulfoxide (DMSO). Cells were harvested in mid-logarithmic growth using standard procedures. The cell count was obtained by pelleting the cells by centrifugation. Cells were put in the freezing medium at a density of approximately $5 \times 10^{6}$ cells $/ \mathrm{ml}$. The cells were aliquoted into sterile vials or ampules. Cells were frozen in a rate-controlled freezer unit overnight. Cells were frozen in the vapor phase of liquid nitrogen.

\subsubsection{Thawing cells}

A vial of cells was removed from the vapor phase of liquid nitrogen. The vial contents were allowed to thaw by continuously swirling the vial in a $37^{\circ} \mathrm{C}$ water bath until only a small ice pellet remained. The vial was sprayed down with a 70\% alcohol solution and was allowed to evaporate. $10-20 \mathrm{ml}$ cold PBS was added to the cells and resuspended. 


\section{Materials and Methods}

Cells were centrifuged at $1000 \mathrm{rpm}$ for 10 minutes at $4^{\circ} \mathrm{C}$. Supernatant was discarded and $10 \mathrm{ml}$ fresh medium was added to the cells. Cells were cultured in an incubator at $37^{\circ} \mathrm{C}$ with $5 \% \mathrm{CO}_{2}$.

\subsubsection{Kill Curve Analysis and stably transfected cells}

Cells are often transfected with expression vectors containing antibiotic (e.g. puromycin or hygromycin) resistance markers that play key role in the enrichment of transfected cells by selectively killing non transfected ones and thereby contributing to the establishment of stably transfected cell lines. To meet such an end, one needs to determine the exact concentration of the selection agent required to achieve a predetermined level of selection. This is done by initially determining the $\mathrm{LD}_{\mathrm{x}}$ (Latent Dose) at which a certain percentage of cells would be alive or dead after being treated by the agent. In the case of establishment of stable cell lines, it is important to determine LD at which there is more than $90 \%$ mortality.

\subsection{Experimental setup}

To predict the concentration of puromycin required to kill $\sim 100 \%$ DG75 cells, a Completely Randomized Design (CRD) was used an experimental model. CRD is a type of statistical experimental design that is equivalent to a t-test when only two treatments are examined. In this model, replications of treatments (concentration of puromycin) are assigned completely at random to independent experimental subjects (cells). Adjacent subjects could potentially have the same treatment. 
Cells were plated in triplicates in a 6 well plate at a density of $5 \times 10^{4}$ cells per well. Except for control group, four different concentrations of puromycin were used: 500 $\mathrm{ng} / \mu 1,750 \mathrm{ng} / \mu 1,1000 \mathrm{ng} / \mu \mathrm{l}, 1250 \mathrm{ng} / \mu \mathrm{l}$.

\subsection{Probit Analysis}

Data obtained was analyzed by SPSS ${ }^{\circledR}$ 15.0. Analysis was done by selecting Probit from the subcategories of Regression Analysis (RA) under the Analysis Toolbar. Probit is a specialized regression model of binomial response variables. The model tries to estimate a linear function that can approximate the sigmoid distribution.

\subsubsection{Transfection}

DG75 cells are normally hard to transfect with chemical tranfection agents. Method of choice is thus to use electric current to transfect the cells.

\subsubsection{Electroporation}

$1 \times 10^{7}$ cells (in $50 \mathrm{ml}$ flask) at mid $\log$ phase were used for the electroporation procedure. The cells were washed with $1 \times$ OPTIMEM. Cells were centrifuged at $500 \times \mathrm{g}$ for 5 minutes. Supernatant was discarded and pellet was washed and mixed gently with $1 \times$ OPTIMEM ( $4-6$ times). Cells were further centrifuged at $500 \times \mathrm{g}$ for 5 minutes. After discarding the supernatant, cells were diluted in $350 \mu$ l OPTIMEM. $5 \mu \mathrm{g}$ of pINCO NGFR and $15 \mu \mathrm{g}$ pRTS-1 constructs were co-electroporated (230 Volts and $1 \mathrm{mF}$ ). 5\% FCS (from 15\% pre-warmed FCS) was added immediately after electroporation.

\subsubsection{Ficoll procedure}

After culturing the cells at $37^{\circ} \mathrm{C}\left(5 \% \mathrm{CO}_{2}\right)$ overnight, $30 \mathrm{ml}$ of the supernatant out of 50 $\mathrm{ml}$ was discarded. Cells were resuspended with the remaining media. $20 \mathrm{ml}$ Ficoll was 


\section{Materials and Methods}

very gently applied to the bottom of the $50 \mathrm{ml}$ conical bottom tube without disturbing the overlay and gently moving up along the border of the Ficoll/medium boundary. Cells were spun in a swinging bucket rotor at $2000 \mathrm{rpm}$ for 30 minutes with deceleration rate of $1 \mathrm{rpm}$ per second. Live cells form a ring at the interface between Ficoll and medium while dead cells settle to the bottom of the flask. The ring was pipetted very gently and mixed with $5 \mathrm{ml}$ fresh medium and spun at $1500 \mathrm{rpm}$ for 5 minutes in a swinging bucket rotor with deceleration rate of $1 \mathrm{rpm}$ per second. Finally, the pellet was resuspended in 50 $\mathrm{ml}$ fresh medium.

\subsubsection{Sorting $\mathrm{NGF}^{+}$cells by MACS}

There is an optimal NGF expression in the transfected cells 2-3 days after transfection. To enrich for transfected cells, Magnetic-Activated Cell Sorting targeting the NGF was used. Approximately $40 \mathrm{ml}$ of the $50 \mathrm{ml}$ old medium was discarded (flasks were kept in standing position). Cells were resuspended with the remaining medium (approx. $10 \mathrm{ml}$ ). $12.5 \mathrm{ml}$ PBS plus MACS Buffer (2.5 g BSA/500 ml approx. 0.5\%; $2 \mathrm{ml}$ EDTA $0.5 \mathrm{M}$ final concentration $2 \mathrm{mM}$ ) was added. Cells were spun at $500 \times \mathrm{g}$ for 5 minutes at $4^{\circ} \mathrm{C}$ (from here onwards, everything was carried out at $4^{\circ} \mathrm{C}$ ). The following cocktails were prepared before the experiment started:

\section{Table 2.18. MACS cocktails}

\begin{tabular}{lcc}
\hline \hline \multicolumn{1}{c}{ Cocktail } & Volume & Description \\
\hline anti NGF antibody mix & $800 \mu \mathrm{l}$ & $720 \mu \mathrm{l}$ of MACS Buffer and $80 \mu \mathrm{l}$ \\
& & of anti NGF antibody \\
\hline Goat anti mouse lgG microbeads & $400 \mu \mathrm{l}$ & $360 \mu \mathrm{l}$ Buffer and $40 \mu \mathrm{l}$ beads \\
\hline
\end{tabular}


The supernatant was discarded and the pellet was resuspended in $400 \mu 1$ anti NGF antibody mix and put at $4^{\circ} \mathrm{C}$ for 20 to 30 minutes. The sample was washed once with ice cold MACS buffer and kept at $4{ }^{\circ} \mathrm{C}$. It was later centrifuged at $500 \times \mathrm{g}$ for 5 minutes at $4^{\circ} \mathrm{C}$. Supernatant was discarded and $200 \mu$ l of Goat anti mouse IgG micro beads was added and mixed. The sample was left on ice for 20 minutes. $15 \mathrm{ml}$ of MACS Buffer was added after the incubation and centrifuged at $500 \times \mathrm{g}$ at $4{ }^{\circ} \mathrm{C}$ for 5 minutes. Following centrifugation, $500 \mu 1$ ice cold MACS buffer was added to soften the beads. In the mean time, MACS columns were equilibrated with $3 \mathrm{ml}$ MACS buffer. The $500 \mu 1$ micro beads solution was added to the pre-equilibrated column and was filled up three times with $3 \mathrm{ml}$ MACS buffer. The column was removed from magnet stand and put on a fresh $15 \mathrm{ml}$ conical bottom falcon tube. $7 \mathrm{ml}$ of MACS buffer was added and the column was plunged with strong force 4 times and the content was collected in the fresh $15 \mathrm{ml}$ tube. This was further centrifuged at $500 \times \mathrm{g}$ for 5 minutes at $4^{\circ} \mathrm{C}$. Finally, after discarding the supernatant, the pellet was solved in approximately $5 \mathrm{ml}$ medium.

\subsubsection{Polymerase Chain Reaction (PCR)}

\subsubsection{Traditional PCR}

Polymerase Chain Reaction is widely held as one of the most important inventions of the 20th century in molecular biology. Small amounts of the genetic material can now be amplified to be able to a identify, manipulate DNA, detect infectious organisms, including the viruses that cause AIDS, hepatitis, tuberculosis, detect genetic variations, including mutations, in human genes and numerous other tasks.

To perform several parallel reactions, master mix was prepared. It contains water, buffer, dNTPs, primers and Taq DNA Polymerase in a single tube, which was then be aliquoted 


\section{Materials and Methods}

into individual tubes. Template DNA was finally added to individual tubes. Master mix preparation is described below.

All solutions were gently vortexed and briefly centrifuged after thawing. In a thin-walled PCR tube put on ice, the following components were added:

Table 2.19. Traditional PCR reaction mix

\begin{tabular}{lll}
\hline \hline Reagent & Final concentration & Quantity for $20 \mu$ l of reaction mixture \\
\hline Sterile deionized water & - & variable \\
\hline 10X Taq thermopol buffer & $1 \mathrm{X}$ & $2 \mu \mathrm{l}$ \\
\hline $10 \mathrm{mM}$ dNTP mix & $0.2 \mathrm{mM}$ of each & $0.4 \mu \mathrm{l}$ \\
\hline Primer Top $(10 \mu \mathrm{M})$ & $0.025 \mu \mathrm{M}$ & $0.5 \mu \mathrm{l}$ \\
\hline Primer Bottom $(10 \mu \mathrm{M})$ & $0.025 \mu \mathrm{M}$ & $0.5 \mu \mathrm{l}$ \\
\hline Taq DNA Polymerase & $0.5 \mathrm{u} / 20 \mu \mathrm{l}$ & $0.125 \mu \mathrm{l}$ \\
\hline Template DNA & $10 \mathrm{pg}-1 \mu \mathrm{g}$ & variable \\
\hline
\end{tabular}

The sample was gently vortexed and briefly centrifuged to collect all drops from walls of tube. Samples were placed in a thermo-cycler with the appropriate program and were run.

\subsubsection{Reverse Transcriptase PCR (RT-PCR)}

RT-PCR is a sensitive and reproducible method for the detection of RNA molecules. It is a two step process (see figure 1):

a. Reverse transcription, a process by which DNA copies are made from RNA template (cDNA synthesis) 


\section{Materials and Methods}

b. PCR/Amplification aims at amplifying sequences of interest from the library

using gene/sequence specific primers

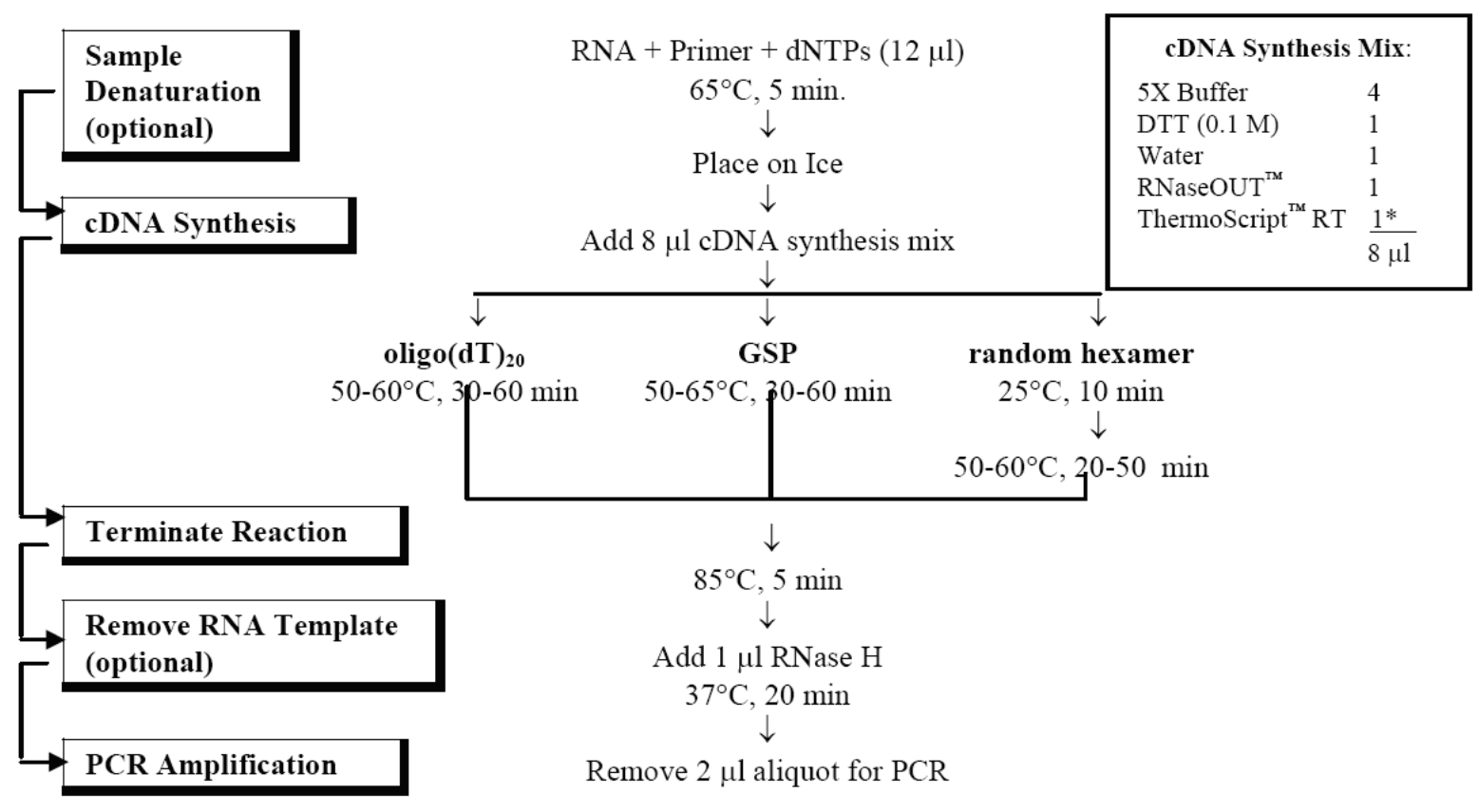

Figure 2.1. Schematic representation of the RT-PCR procedure (adapted from Invitrogen Inc.)

cDNA synthesis: The following components were mixed in $1.5 \mathrm{ml}$ microfuge:

Table 2.20. RT-PCR first reaction mix (Primers, dNTPs and RNA)

\begin{tabular}{ll}
\hline \hline Component & Amount \\
\hline Primer $(50 \mathrm{ng} / \mu \mathrm{l})$ & $1 \mu \mathrm{l}$ \\
\hline RNA $(10 \mathrm{pg}-5 \mu \mathrm{g})$ & $\mathrm{x} \mu \mathrm{l}$ \\
\hline $10 \mathrm{mM}$ dNTP Mix & $2 \mu \mathrm{l}$ \\
\hline DEPC-treated water & to $12 \mu \mathrm{l}$ \\
\hline
\end{tabular}




\section{Materials and Methods}

The mix was denatured by incubating at $65^{\circ} \mathrm{C}$ for $5 \mathrm{~min}$ and later placed on ice. $5 \mathrm{X}$ cDNA Synthesis Buffer was vortexed for $5 \mathrm{~s}$ just prior to use. Master reaction mix was prepared, as per the following composition, on ice and vortexed gently.

Table 2.21. RT-PCR first strand synthesis mix

\begin{tabular}{|c|c|}
\hline Component & Amount \\
\hline $5 x$ cDNA Synthesis Buffer & $4 \mu \mathrm{l}$ \\
\hline $0.1 \mathrm{M} \mathrm{DTT}$ & $1 \mu \mathrm{l}$ \\
\hline RNaseOUT. (40 U/pl) & $1 \mu \mathrm{l}$ \\
\hline DEPC-treated water & $1 \mu \mathrm{l}$ \\
\hline ThermoScript. RT (15 units/ $\mu \mathrm{l})$ & $1 \mu \mathrm{l}$ \\
\hline
\end{tabular}

$8 \mu \mathrm{l}$ of master reaction mix was pipetted into each reaction tube on ice and transferred to a preheated thermal cycler with the following program: $25^{\circ} \mathrm{C}$ for $10 \mathrm{~min}$, followed by 20 $50 \mathrm{~min}$ at $50^{\circ} \mathrm{C}$ (or $50-65^{\circ} \mathrm{C}$ ). Reaction was terminated by incubating at $85^{\circ} \mathrm{C}$ for $5 \mathrm{~min}$. Finally, $1 \mu \mathrm{l}$ of RNase $\mathrm{H}$ was added and sample was incubated at $37^{\circ} \mathrm{C}$ for $20 \mathrm{~min}$. Sample was stored at $-20^{\circ} \mathrm{C}$ or used for PCR immediately.

Amplification: PCR was carried out using Platinum ${ }^{\circledR}$ Taq DNA Polymerase High Fidelity. $10 \%$ of the cDNA synthesis reaction $(2 \mu \mathrm{l})$ was used for PCR. The following components were mixed in a $0.2-$ or $0.5-\mathrm{ml}$, thin-walled, PCR tube: 
Table 2.21. PCR mix for gene specific amplification from cDNA

\begin{tabular}{ll}
\hline \hline Component & Amount \\
\hline $10 X$ High Fidelity PCR Buffer & $5 \mu \mathrm{l}$ \\
\hline $50 \mathrm{mM} \mathrm{MgSO}_{4}$ & $2 \mu \mathrm{l}$ \\
\hline $10 \mathrm{mM}$ dNTP Mix & $1 \mu \mathrm{l}$ \\
\hline $10 \mu \mathrm{M}$ sense primer & $1 \mu \mathrm{l}$ \\
\hline $10 \mu \mathrm{M}$ antisense primer & $0.2 \mu \mathrm{l}$ \\
\hline Platinum ${ }^{\circledR}$ Taq High Fidelity & $2 \mu \mathrm{l}$ \\
\hline cDNA (from cDNA synthesis reaction) & $37.8 \mu \mathrm{l}$ \\
\hline DEPC-treated water & $50 \mu \mathrm{l}$ \\
\hline Final volume & 10 \\
\hline
\end{tabular}

Samples were mixed gently and put in a preheated thermocycler with the following settings:

Table 2.22. PCR program setup for detection of CALM/AF10 from cDNA preparation

\begin{tabular}{|c|c|c|}
\hline Temperature & Time & Remark \\
\hline $94^{\circ} \mathrm{C}$ & $2 \min$ & Hold \\
\hline $94^{\circ} \mathrm{C}$ & 30 seconds & \\
\hline $54.7^{\circ} \mathrm{C}$ (temp depends on primers) & 30 seconds & 30 cycles \\
\hline $68^{\circ} \mathrm{C}$ & $1 \mathrm{~min} / \mathrm{kb}$ extension & \\
\hline $68^{\circ} \mathrm{C}$ & 7 minutes & Final Extension \\
\hline $4^{\circ} \mathrm{C}$ & $\infty$ & Hold \\
\hline
\end{tabular}




\section{Materials and Methods}

$10 \mu \mathrm{l}$ of the amplified sample was analyzed by agarose gel electrophoresis.

\subsubsection{Colony PCR}

This protocol is designed to quickly screen for plasmid inserts directly from $E$. coli colonies. This technique can be used to determine insert size and/or orientation in the vector. Colonies from successful ligation/transformation reaction were picked and cultured in LB medium with the appropriate selection agent overnight at $37^{\circ} \mathrm{C}$ in a shaker set to $230 \mathrm{rpm}$.

The next day, the following ingredients were mixed on ice:

Table 2.23. Reaction mix for colony PCR

\begin{tabular}{ll}
\hline \hline Component & Amount \\
\hline sterile distilled water & $38 \mu \mathrm{l}$ \\
\hline $10 \mathrm{X}$ PCR buffer & $5 \mu \mathrm{l}$ \\
\hline $25 \mathrm{mM} \mathrm{MgCl}_{2}$ & $3 \mu \mathrm{l}$ \\
\hline $10 \mathrm{mM}$ dNTPs (10 mM each dATP, dTTP, dGTP, dCTP) & $1 \mu \mathrm{l}$ \\
\hline $20 \mu \mathrm{M}$ forward primer & $1 \mu \mathrm{l}$ \\
\hline $20 \mu \mathrm{M}$ reverse primer & $1 \mu \mathrm{l}$ \\
\hline Taq polymerase & $0.2-1 \mu \mathrm{l}$ \\
\hline Total volume & $50 \mu \mathrm{l}$ \\
\hline
\end{tabular}

To each cold PCR tube containing the PCR reaction, $1 \mu$ from the overnight culture was added and mixed thoroughly. 
Table 2.24. Program setup for colony PCR

\begin{tabular}{lll}
\hline \hline Temperature & Time & Remark \\
\hline $95^{\circ} \mathrm{C}$ & $5 \mathrm{~min}$ & Lysis and denaturation \\
\hline $95^{\circ} \mathrm{C}$ & $1 \mathrm{~min}$ & DNA denatures into single \\
& & strands \\
\hline $54^{\circ} \mathrm{C}$ (temp depends on primers) & $1.5 \mathrm{~min}$ & $30-40$ cycles \\
\hline $72^{\circ} \mathrm{C}$ & $1 \mathrm{~min}(1 \mathrm{~min} / \mathrm{kb})$ & primers are extended from \\
& & 3 '-end by Taq \\
\hline $72^{\circ} \mathrm{C}$ & $5 \mathrm{~min}$ & final extension \\
\hline $4^{\circ} \mathrm{C}$ & $\infty$ & Hold \\
\hline
\end{tabular}

\subsubsection{Real Time PCR (Applied Biosystems 7900HT Micro Fluidic Card)}

The Micro Fluidic Card allows you to use the $7900 \mathrm{HT}$ system for profiling gene expression using the Comparative $\mathrm{C}_{\mathrm{T}}$ Method of relative quantification. The card evaluates from one to eight cDNA samples or controls generated from total RNA in a two-step RT-PCR. The following protocol describes, adopted with some modifications from Applied Biosystems 7900HT Micro Fluidic Card Getting Started Guide(Biosystems, 2003), the steps following post cDNA synthesis.

\subsubsection{Amount of CDNA in the PCR Mix}

Each $100 \mu \mathrm{l}$ PCR mix, enough to fill one reservoir, contained $33.75 \mathrm{ng}$ of total RNA converted to cDNA. The cDNA sample volume, with added water, was $50 \mu \mathrm{l}$. cDNA sample was thawed by rolling the tube between fingers. Sample was gently vortexed and centrifuged. The following components were added to a labeled 1.5-ml microcentrifuge tube: 


\section{Materials and Methods}

Table 2.25. Sample reaction mix for Low Density Array real-time PCR

\begin{tabular}{lc}
\hline \hline Component & Volume Per Fill Reservoir $(\boldsymbol{\mu l})$ \\
\hline cDNA & 0.75 \\
\hline $\mathrm{H}_{2} \mathrm{O}$ & 49.25 \\
\hline TaqMan® Universal PCR Master Mix (2X) & 50 \\
\hline Total & 100 \\
\hline
\end{tabular}

The micro-centrifuge tube was capped and thoroughly mixed by gentle vortexing. The tube was centrifuged to eliminate air bubbles from the mixture. The Micro Fluidic Card was loaded with samples as per the recommended guideline.

Table 2.26. List of different LDA cards available from Applied Biosystems $®$

\begin{tabular}{|c|c|c|c|c|c|}
\hline $\begin{array}{l}\text { TaqMan Low } \\
\text { Density Array }\end{array}$ & $\begin{array}{l}\text { Number of } \\
\text { Targets and } \\
\text { Controls }\end{array}$ & $\begin{array}{l}\text { Number of } \\
\text { Assay } \\
\text { Replicates }\end{array}$ & $\begin{array}{l}\text { Number of } \\
\text { Samples per } \\
\text { Card }\end{array}$ & $\begin{array}{l}\text { Minimum } \\
\text { Order Size }\end{array}$ & Part Number \\
\hline Format 12 & $11+1$ & 4 & 8 & 20 & 4342247 \\
\hline Format 16 & $15+1$ & 3 & 8 & 20 & 4346798 \\
\hline Format 24 & $23+1$ & $2(4)$ & $8(4)$ & 20 & 4342249 \\
\hline Format 32 & $31+1$ & 3 & 4 & 20 & 4346799 \\
\hline Format 48 & $47+1$ & $2(4)$ & $4(2)$ & 10 & 4342253 \\
\hline Format 64 & $63+1$ & 3 & 2 & 20 & 4346800 \\
\hline Format 96a* & $95+1$ & $2(4)$ & $2(1)$ & 10 & 4342259 \\
\hline Format $96 b$ & $95+1$ & $2(4)$ & $2(1)$ & 20 & 4342261 \\
\hline Format 384 & $380+1$ & 1 & 1 & 50 & 4342265 \\
\hline
\end{tabular}

\section{* Type of card used}


Applied Biosystems provides 9 formats of Low Density Array (LDA) cards. Format 96a was used in this experiment. 95 genes that had been found to be differentially regulated were selected for the custom setup. The table above gives details about the types of cards available.

Once samples were loaded, the fluidics card was centrifuged in a Heraeus centrifuge with bucket settings. The following table lists the operational parameters for Micro Fluidic Cards.

Table 2.27. Centrifugation generic setup for LDA cards

\begin{tabular}{lll}
\hline \hline Parameter & QUIKSet & EASYSet \\
\hline Up ramp rate & 3 & 9 \\
\hline Down ramp rate & N/A & 9 \\
\hline Rotational speed & $1200 \mathrm{rpm}$ & $1200 \mathrm{rpm}$ \\
\hline Centrifugation time & $2 \times 1 \mathrm{~min}(0.01$ on display $)$ & $2 \times 1 \mathrm{~min}(0.01$ on display $)$ \\
\hline
\end{tabular}

Following centrifugation based on the above settings, the fluidics card was sealed and sample loader was trimmed.

\subsubsection{Program setup and run}

Sequence Detection Software version 2.1 (SDS 2.1) was used to run the fluidics cards and acquire data. Further data analysis was also performed using SDS 2.1. New template file was created using the options Relative Quantification $\left(\Delta \Delta \mathrm{C}_{\mathrm{t}}\right)$ and 384 well cards. 


\section{Materials and Methods}

After a new document template has been created, the default thermal cycling conditions for Micro Fluidics Cards were set (See table below).

Table 2.28. Applied Biosystems $®$ 7900HT real-time PCR reaction instrument setup for LDA

\begin{tabular}{|c|c|c|c|}
\hline \multirow[t]{2}{*}{ AmpErase UNG Activation } & \multirow{2}{*}{$\begin{array}{l}\text { AmpliTaq Gold DNA } \\
\text { Polymerase Activation }\end{array}$} & \multicolumn{2}{|c|}{ Each of 40 Cycles } \\
\hline & & Melt & Anneal/Extend \\
\hline $50{ }^{\circ} \mathrm{C}$ & $94.5^{\circ} \mathrm{C}$ & $97^{\circ} \mathrm{C}$ & $59.7^{\circ} \mathrm{C}$ \\
\hline $2 \min$ & $10 \mathrm{~min}$ & $30 \mathrm{sec}$ & $1 \mathrm{~min}$ \\
\hline $100 \%$ ramp & $100 \%$ ramp & $50 \%$ ramp & $100 \%$ ramp \\
\hline
\end{tabular}

\subsubsection{Microarray Analysis}

This protocol is a summary of the extensive protocol provided by Affymetrix ${ }^{\circledR}($ Affymetrix, 2005). Further details are found in the complete standard operation manual (Figure 2.2 summarizes the workflow). The procedure requires a minimum of $5 \mu \mathrm{g}$ of purified total RNA as starting material.

\subsubsection{First-Strand cDNA Synthesis}

$5 \mu \mathrm{g}$ of total RNA was added to a $1.5-\mathrm{ml}$ RNase-free tube and mixed with $1 \mu \mathrm{l}$ of 100 $\mathrm{pmol} / \mu \mathrm{l}$ T7-(dT)24 primer. Volume was adjusted to $12 \mu \mathrm{l} /$ reaction with nuclease-free water. The mix was incubated at $65^{\circ} \mathrm{C}$ for 10 minutes and centrifuged briefly at about $10,000 \mathrm{rpm}$ for $10 \mathrm{sec}$ and placed on ice. $4 \mu \mathrm{l}$ of $5 \mathrm{X}$ first-strand cDNA buffer, $2 \mu \mathrm{l}$ of 0.1 $\mathrm{M}$ dithiothreitol (DTT), and $1 \mu \mathrm{l}$ of $10 \mathrm{mM}$ dNTP mix were added and mixed well. The sample was incubated at $42{ }^{\circ} \mathrm{C}$ for $2 \mathrm{~min}$. Following the addition of $1 \mu \mathrm{l}$ of $200 \mathrm{U} / \mu \mathrm{l}$ SuperScript II RT, the mix was further incubated at $42{ }^{\circ} \mathrm{C}$ for $1 \mathrm{hr}$ and finally centrifuged briefly at about $10,000 \mathrm{rpm}$ for $10 \mathrm{sec}$ and placed on ice. 
(a)

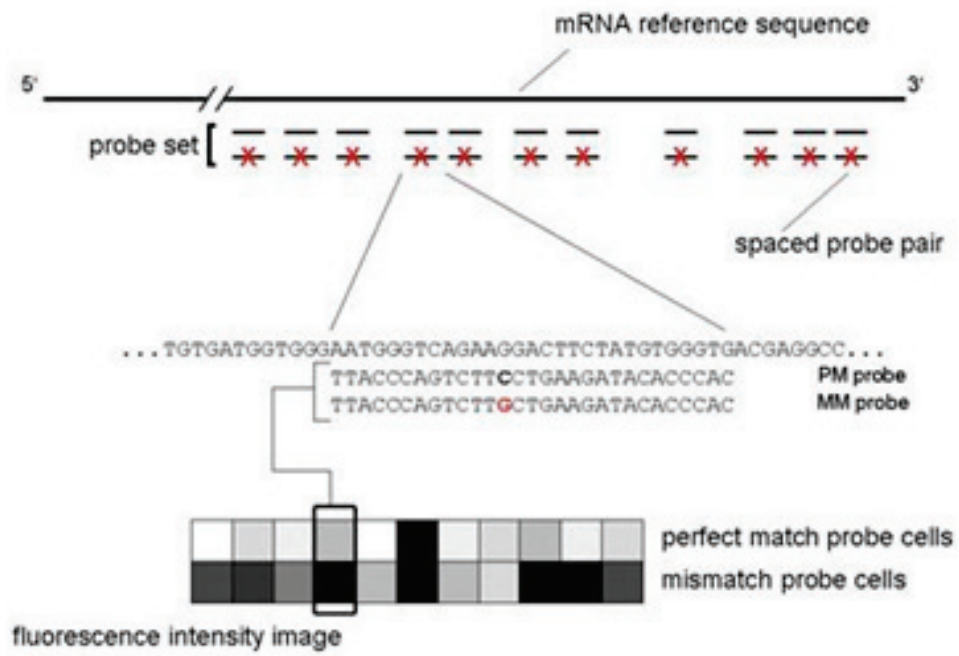

(b)
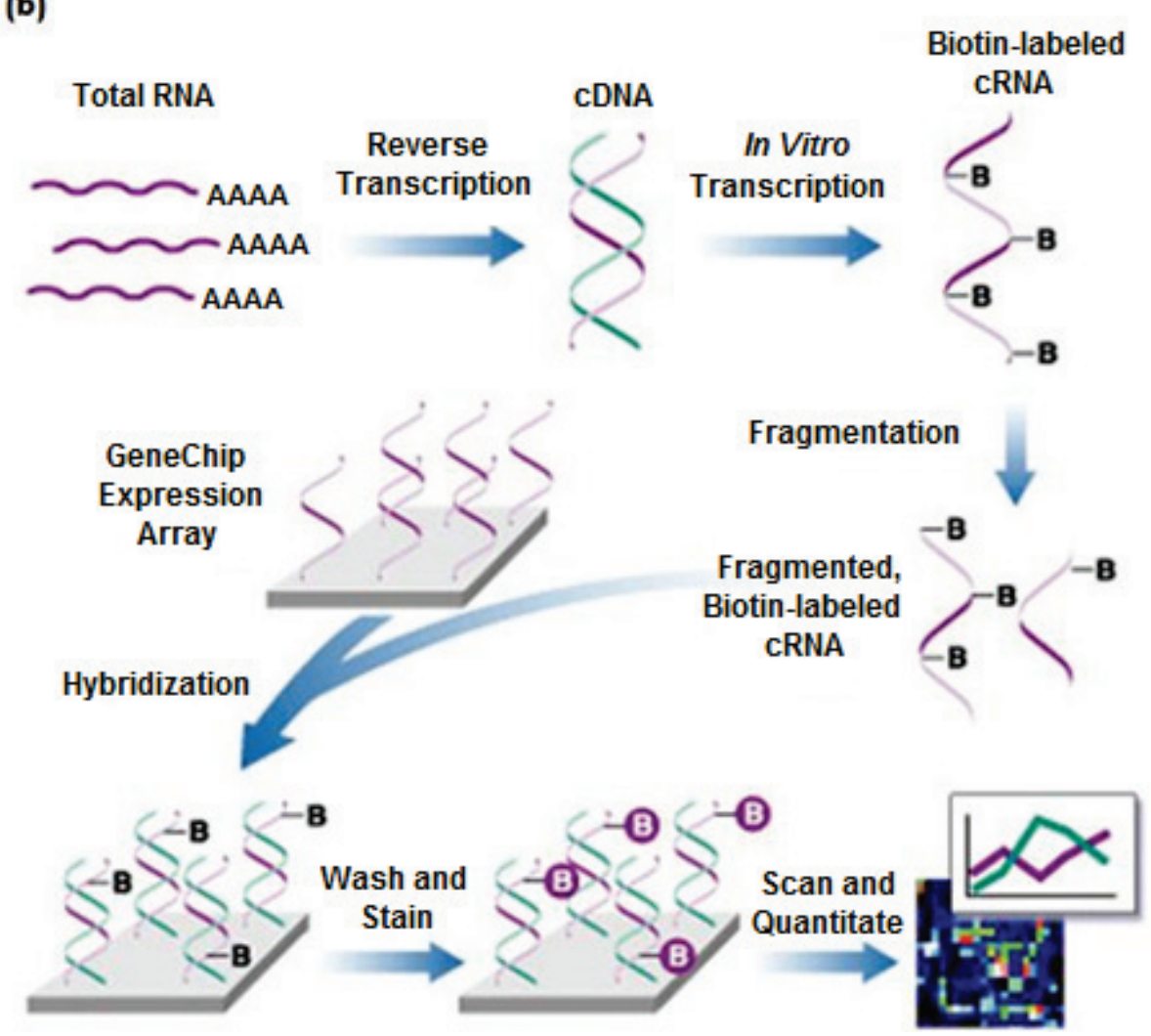

Figure 2.2. (a) A set of short oligonucleotides matching to different parts of an mRNA reference sequence is designed and is referred to as a probeset. A probeset contains pairs of oligonucleotides that either perfectly match (Perfect Match probe, PM) or contain a single mismatch (MisMatch probe, MM, serving as negative control) to the reference mRNA. (b) Affymetrix microarray workflow (both images adapted from http://www.dkfz.de/gpcf/24.html). 


\section{Materials and Methods}

\subsubsection{Second-Strand cDNA Synthesis}

$30 \mu \mathrm{l}$ of $5 \mathrm{x}$ second-strand reaction buffer, $3 \mu \mathrm{l}$ of $10 \mathrm{mM}$ dNTP mix, $1 \mu \mathrm{l}$ of $10 \mathrm{U} / \mu 1 E$. coli DNA ligase, $4 \mu \mathrm{l}$ of $10 \mathrm{U} / \mu \mathrm{l}$ DNA polymerase I, $1 \mu \mathrm{l}$ of $2 \mathrm{U} / \mu \mathrm{l}$ RNase $\mathrm{H}$, and $91 \mu \mathrm{l}$ of nuclease-free water were added to the first strand cDNA synthesis reaction and incubated at $16^{\circ} \mathrm{C}$ for $2 \mathrm{hrs} .2 \mu \mathrm{l}$ of $5 \mathrm{U} / \mu \mathrm{l}$ T4 DNA polymerase was added and the mix was further incubated at $16{ }^{\circ} \mathrm{C}$ for $5 \mathrm{~min} .10 \mu \mathrm{l}$ of $0.5 \mathrm{M}$ EDTA was added prior to proceeding to cleanup and precipitation.

\subsubsection{3. cDNA Cleanup and Precipitation}

$600 \mu 1$ of cDNA binding buffer (from GeneChip Sample Cleanup Module) was added to the synthesized cDNA. The sample was applied to a cDNA cleanup spin column sitting in a $2-\mathrm{ml}$ collection tube and centrifuged at $8000 \mathrm{xg}$ for $1 \mathrm{~min}$. The flow-through was discarded. The collection tube was replaced with another 2-ml collection tube. $750 \mu 1$ of cDNA wash buffer was added to the spin column and centrifuged at $8000 \mathrm{x}$ g for $1 \mathrm{~min}$. The flow-through was again discarded.21. The spin column was centrifuged at maximum speed for 5 min with the column cap opened. The column was transferred to a fresh 1.5$\mathrm{ml}$ collection tube and $14 \mu \mathrm{l}$ cDNA elution buffer was pipetted directly onto the column membrane. Centrifuge at $8000 \mathrm{xg}$ for $1 \mathrm{~min}$ to elute DNA.

\subsubsection{Biotin-Labeled cRNA Synthesis}

$10 \mu 1$ of sample cDNA, $4 \mu 1$ of $10 \mathrm{x}$ HighYield (HY) reaction buffer, $4 \mu 1$ of biotinlabeled ribonucleotides, $4 \mu 1$ of DTT, $4 \mu 1$ of RNase inhibitor mix, and $2 \mu 1$ of 20x T7 RNA polymerase were mixed with nuclease-free water to provide a final reaction volume of $40 \mu 1$. The mix was incubated at $37^{\circ} \mathrm{C}$ for $5 \mathrm{hr}$. For cleanup and quantification, the sample volume was adjusted to $100 \mu 1$ with nuclease-free water and $350 \mu 1$ of IVT cRNA 
binding buffer was added and mixed well by pipetting. $250 \mu 1$ of $100 \%$ ethanol was added and mixed well by pipetting gently 4 to 5 times. Sample was applied to an IVT cRNA cleanup spin column sitting in a 2 -ml collection tube and centrifuged at $8000 \mathrm{x} \mathrm{g}$ for $15 \mathrm{sec}$. The column was transferred to a fresh collection tube and $500 \mu 1$ IVT cRNA wash buffer was added. Further centrifugation was carried out at $8000 \mathrm{x}$ g for $15 \mathrm{sec}$. The flow-through was discarded and the column returned to same collection tube. $500 \mu 1$ of $80 \%$ ethanol was added and centrifuged at $8000 \mathrm{x}$ g for $15 \mathrm{sec}$. The spin column was centrifuged at maximum speed for 5 min with the column cap opened to dry the column membrane. The column was transferred to a fresh $1.5-\mathrm{ml}$ collection tube and $25 \mu \mathrm{l}$ of nuclease-free water was pipetted directly onto the column membrane and centrifuged at $25,000 \mathrm{x} \mathrm{g}$ for $1 \mathrm{~min}$ to elute RNA. The RNA yield was determined by spectrophotometric analysis, applying the convention that $1 \mathrm{OD}$ at $260 \mathrm{~nm}$ equals 40 $\mu \mathrm{g} / \mathrm{ml}$ RNA.

\subsubsection{5. cRNA Fragmentation}

$8 \mu \mathrm{l}$ of $5 \mathrm{x}$ fragmentation buffer was added to $20 \mu \mathrm{g}$ of cRNA and the total volume was brought to $40 \mu 1$ with nuclease-free water. The mix was incubated at $94^{\circ} \mathrm{C}$ for $35 \mathrm{~min}$ and placed on ice.

\subsubsection{Array Hybridization}

$10 \mu \mathrm{g}$ of fragmented cRNA was mixed with $3.3 \mu 1$ of $3 \mathrm{nM}$ control oligonucleotide $\mathrm{B} 2$, $10 \mu 1$ of 20X eukaryotic hybridization control, $2 \mu 1$ of $10 \mathrm{mg} / \mathrm{ml}$ herring sperm DNA, $2 \mu 1$ of $50 \mathrm{mg} / \mathrm{ml}$ acetylated BSA, $100 \mu \mathrm{l}$ of $2 \mathrm{X}$ hybridization buffer, and nuclease-free water to a final volume of $200 \mu 1$. The probe array was equilibrated to room temperature before use. The hybridization mixture was incubated at $99^{\circ} \mathrm{C}$ for $5 \mathrm{~min}$. In the meantime, the 


\section{Materials and Methods}

probe array was filled with $160 \mu \mathrm{l}$ of $1 \mathrm{X}$ hybridization buffer and incubated at $45^{\circ} \mathrm{C}$ for $15 \mathrm{~min}$. The buffer was removed from the probe array and the array was filled with 200 $\mu 1$ of hybridization mixture. The filled array was placed in a rotisserie box heated to $45^{\circ} \mathrm{C}$ for $16 \mathrm{hrs}$.

\subsubsection{Array Post-Hybridization Washing}

All required buffers and staining reagents, including nonstringent wash buffer, stringent wash buffer, streptavidin-phycoerythrin (SAPE) stain solution, and antibody solution mix were prepared prior to washing procedure. The Fluidics Station was turned on. From the Microarray Suite, the Fluidics option was run. The Fluidics Station was primed by selecting Protocol $\rightarrow$ Prime from the drop-down menu.

The nonstringent wash buffer was placed in reservoir A while the stringent wash buffer was placed in reservoir B. The nuclease-free was poured into the water reservoir. Run was executed to begin priming. Experiment file for each probe array was created by clicking Run $\rightarrow$ Experiments Info. The hybridization mixture was transferred from the probe array to a tube. The probe array was fully loaded with $160 \mu 1$ of nonstringent wash buffer. From the Fluidics window, the drop-down menu below Experiment was clicked to select the correct experiment name; the drop-down menu below Protocol was also clicked to select the appropriate protocol. Once the setup was done, Run command was executed to begin washing and staining. The instructions on the monitor were followed and the probe array was inserted when prompted. The microcentrifuge tube was removed from the sample holder of the Fluidics Station. A microcentrifuge tube containing $600 \mu 1$ of SAPE stain solution was placed in the sample holder. Further instructions on the monitor were followed and when prompted, the microcentrifuge with the staining 
solution was replaced with a microcentrifuge tube containing $600 \mu 1$ of antibody solution mix. Furthermore, another microcentrifuge tube containing $600 \mu 1$ of SAPE stain solution was put in place after being prompted for it. The Fluidics Station was allowed to continue until the EJECT CARTRIDGE message appeared on the monitor, indicating the completion of the protocol. The probe array was removed from the GeneChip Fluidics Station for scanning protocol. 


\section{Results}

\section{Results}

\subsection{Cloning experiments}

\subsubsection{Cloning of FLAG-CALM/AF10 into the pUC19 Shuttle Vector}

The CALM/AF10 fusion gene that was used for this work was a FLAG-CALM/AF10 openreading frame (ORF) that was cloned in the pEYFP vector using $X b a \mathrm{I}$ and $X h o \mathrm{I}$ (Figure 3.1b). pEYFP vector doesn't contain the appropriate restriction site (SfiI site) required to clone CALM/AF10 into the desired conditional mammalian expression vector pRTS-1 (Figure 3.3a and $3.3 \mathrm{~b}$ ). To facilitate the cloning procedure, FLAG-CALM/AF10 was first cloned into a shuttle vector that contains SfiI cassette (pUC19 vector).

The $X b a \mathrm{I}$ and $X h o \mathrm{I}$ sites were used to clone FLAG-CALM/AF10 ORF into the plasmid pUC19 SfiI Shuttle Vector (Figure 1a). CALM/AF10 was cut out from the pEYFP vector backbone by using XhoI, XbaI, and NsiI (Figure 3.1c, lanes 7 to 10). The pUC19 Shuttle Vector was digested with XhoI and XbaI (Figure 3.1c, lanes 1 to 5).

\subsubsection{Cloning of VP16 upstream of FLAG-CALM/AF10}

The VP16 transactivating domain, a strong transactivating domain which is able to transactivate almost all promoter types, was cloned up-stream and in-frame to the CALM/AF10 fusion protein in order to convert CALM/AF10 from a transcriptional repressor into a strong transcriptional activator of these promoters thus leading to a clear detection of genes, in the microarray analysis, that are normally down-regulated by CALM/AF10. It should be noted that this is an additional clone. The transactivation domain of VP16 (tVP16) cloning was carried out by first amplifying the tVP16 from the pVP-FLAG vector by adding Not I and XhoI sites to the forward and reverse primers, 
respectively. These restriction sites were later used for cloning the tVP16 into the pUC19-FLAG-CALM/AF10 construct (Fig 3.1a and 3.1b). 


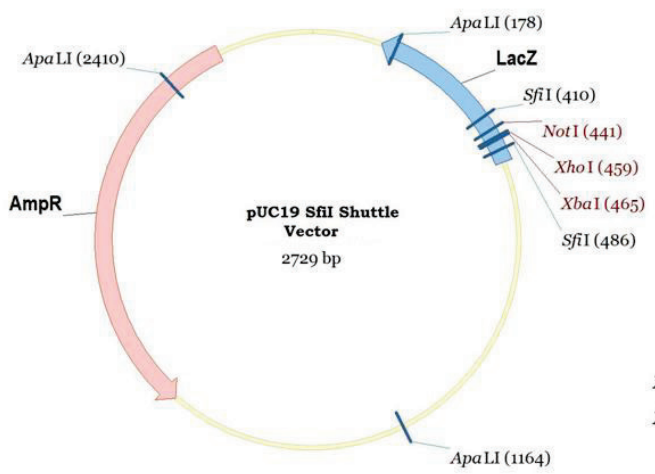

(a)

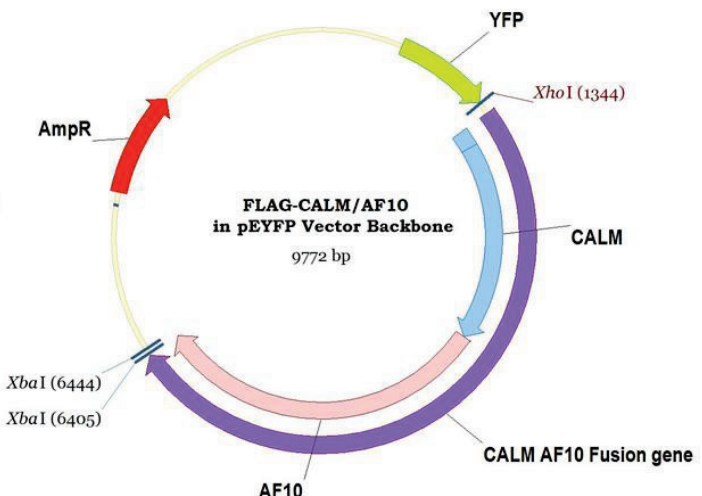

(b)

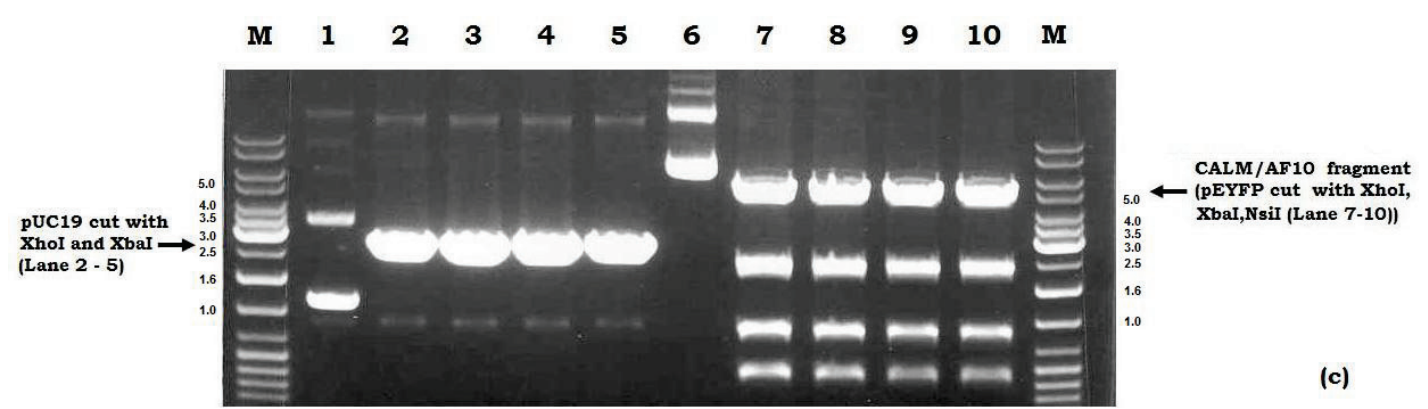

Figure 3.1. Cloning of FLAG-CALM/AF10 into the pUC19 shuttle vector. (a) the pUC19 shuttle vector (b) pEYFP-FLAG-CALM/AF10 (c) Agarose gel showing the fragments produced by the restriction digestion, arrows indicating desired fragments. $M$ is the DNA ladder used and fragment sizes are given on the left and right hand side of the gel (in $\mathrm{kbp}$ ).

(a)
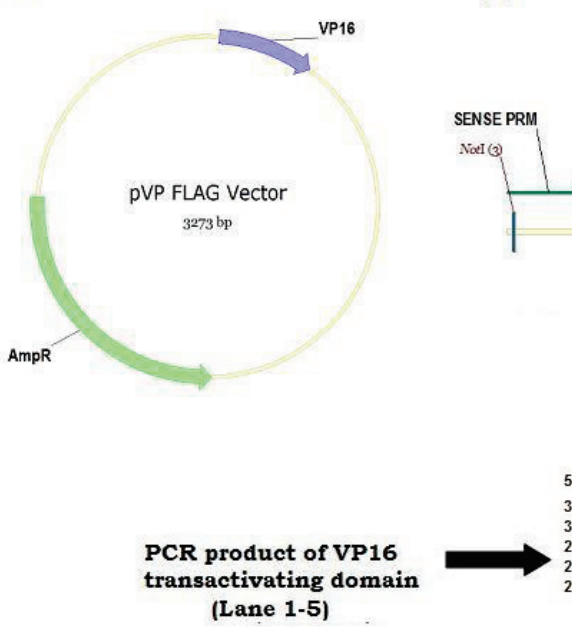

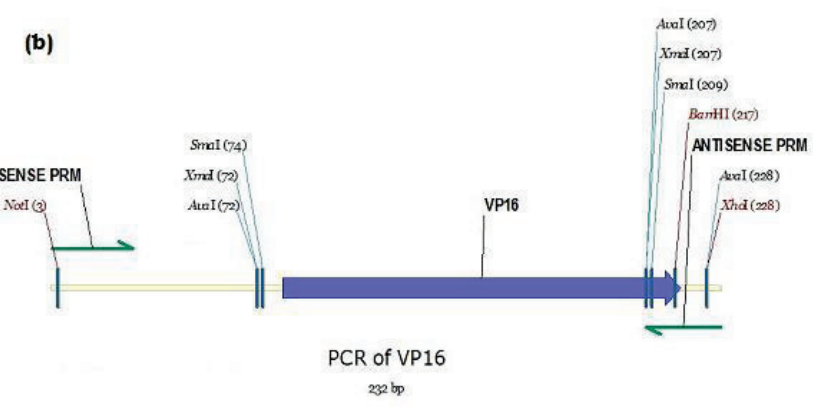

$\begin{array}{lllllll}M & 1 & 2 & 3 & 4 & 5 & M\end{array}$

(c)

Figure 3.2. Schematic diagram of the pVP-FLAG vector containing the VP16 transactivating domain (a). Diagram (b) and gel (c) showing the PCR product and size. M is the DNA ladder used and fragment sizes are given on the left hand side of the gel (in bp). 


\subsubsection{Cloning of FLAG-CALM/AF10 and FLAG-VP16-CALM/AF10 into pRTS-1}

pRTS-1 is an EBV-derived episomally replicating plasmid that carries all the elements for conditional expression of a gene of interest via Tet regulation. The vector is characterized by

(i) low background activity,

(ii) high inducibility in the presence of doxycycline (Dox) and

(iii) graded response to increasing concentrations of the inducer (Bornkamm et al., 2005).

The gene of interest is expressed from the bidirectional promoter $\mathrm{P}_{\text {tet }} \mathrm{bi}-1$ that allows simultaneous expression of two genes, of which one may be used as surrogate marker for the expression of the gene of interest. Tight down regulation is achieved through binding of the silencer tTSKRAB to $\mathrm{P}_{\text {tet }} \mathrm{bi}-1$ in the absence of the inducer (e.g. Doxycycline, Dox). Addition of Dox releases repression and via binding of $\mathrm{rtTA}^{\mathrm{S}}-\mathrm{M} 2$ activates the promoter $\mathrm{P}_{\text {tet }}$ bi-1. pRTS-1 has the GFP gene on one side of the promoter and the firefly luciferase gene on the other. Two SfiI sites flank the luciferase gene.

VP16-FLAG-CALM/AF10 and FLAG-CALM/AF10 (without VP16) were cloned into pRTS-1 using SfiI restriction sites (Figure 3.3c). SfiI has a bipartite recognition sequence (two 4 nucleotide sequences) flanking a core of 5 not-defined nucleotides. The enzyme creates a 3 nucleotide long' bverhang in this non -defined internal pentanucleodtide. DNA fragments cut with SfiI will only religate if the 3 nucleotides of this $3^{\prime}$ overhang are complementary, which is the case in for the SfiI sites in the pUC19-SfiI shuttle vector and pRTS-1. This allows the easy directional cloning of fragments from the pUC19-SfiI shuttle into the pRTS-1 vector. 


\section{Results}

(a)
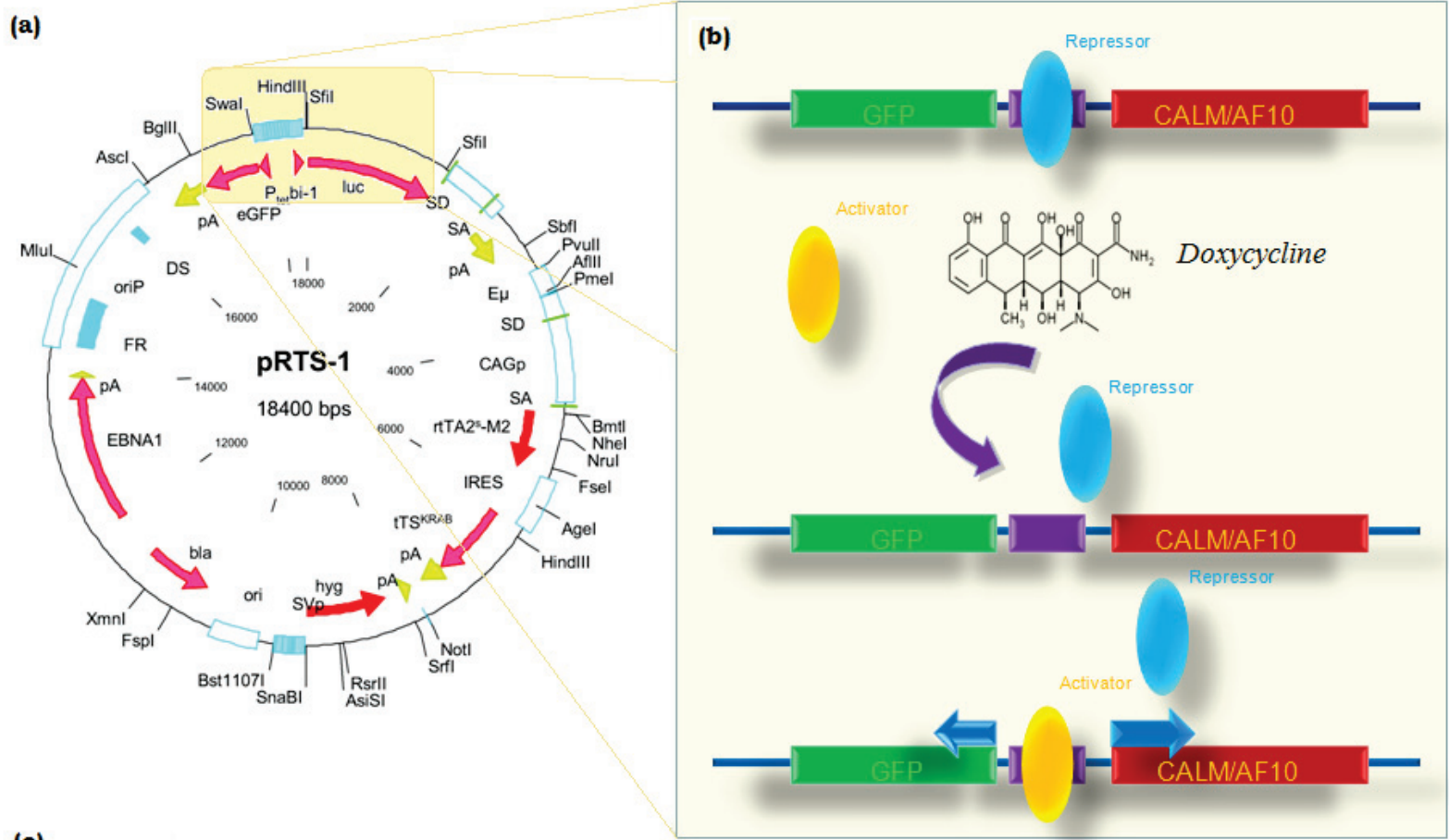

(c)

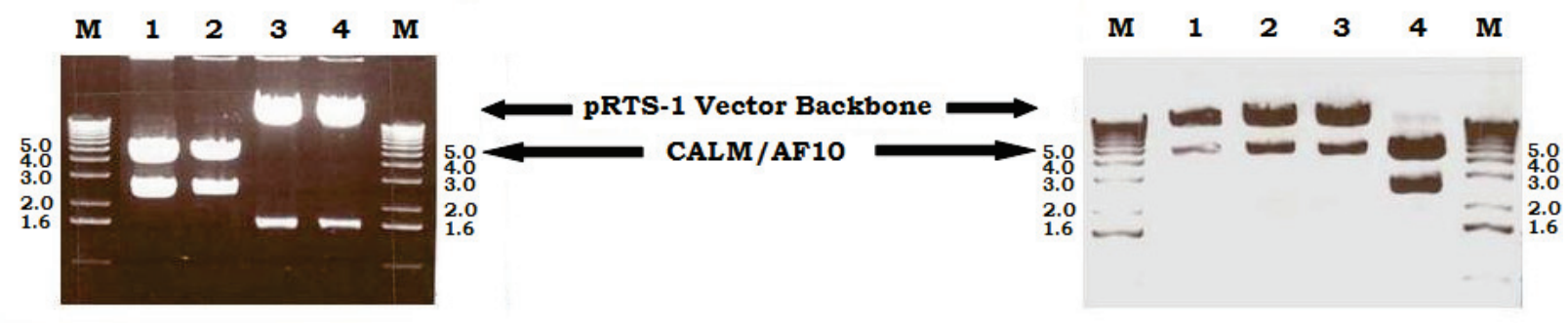

Figure 3.3. (a) Schematic diagram of pRTS-1 expression vector, (b) illustration showing how the bidirectional promoter works, (c) Agrose gels showing the pRTS-1 backbone (upper bands) and Luciferase (lower bands) after SfiI digestion (Left gel, lanes 3 and 4). Lanes 1 and 2 in the same gel show Sfil digested FLAG-CALM/AF10 and VP16-FLAG-CALM/AF10 (upper bands), respectively, the lower bands are the vector backbone of pUC19 Shuttle Vector. Right gel (lanes 1 to 3) shows SfiI digestion upon successful cloning of CALM/AF10 (lower bands) into the pRTS-1 vector (upper bands). $M$ is the DNA ladder used and fragment sizes are given on the left and right hand sides of the gels (in $\mathrm{kbp}$ ).

\subsection{Establishing a stably transfected cell line}

There are many different approaches for establishing stable cell lines, depending on the type of expression one is interested in (inducible vs. constitutive) and the construct to be used. The desired end result is a population of cells in which $>95 \%$ of the cells are 
expressing the protein of interest at approximately the same level. This allows large-scale biochemical analyses of the protein and monitoring of localization throughout the cell cycle, and greatly simplifies many other microscopy techniques as well (Lamond, 2008). DG75 is a human Burkitt lymphoma cell line that was originally established from the pleural effusion of a 10-year-old boy with Burkitt lymphoma in 1975 (Ben-Bassat et al., 1977). It has a near diploid karyotype with a $\mathrm{t}(8 ; 14)$ with $6 \%$ polyploidy - $46 \mathrm{XY}$, $\mathrm{t}(8 ; 14)(\mathrm{q} 24 ; \mathrm{q} 32)$.

\subsubsection{Electroporation/transfection}

Electroporation was carried out as per the protocol described in the materials and methods section. DG75 cells were transfected with the following vectors and constructs:

Table 3.3. Type of constructs/vectors and amount of DNA used for the electroporation procedure

\begin{tabular}{lll}
\hline \hline Construct/Vector & $\begin{array}{l}\text { Amount used per } \\
1 \times 10^{7} \text { cells }\end{array}$ & Remark \\
\hline pRTS-1-FLAG-CALM/AF10 & $15 \mu \mathrm{g}$ & $\begin{array}{l}\text { Co-transfected with } 5 \mu \mathrm{g} \text { of NGFR } \\
\text { expressing vector (pINCO) }\end{array}$ \\
\hline pRTS-1-VP16-FLAG-CALM/AF10 & $15 \mu \mathrm{g}$ & $\begin{array}{l}\text { Co-transfected with } 5 \mu \mathrm{g} \text { of NGFR } \\
\text { expressing vector (pINCO) }\end{array}$ \\
\hline pRTS-1 vector backbone & & Co-transfected with $5 \mu \mathrm{g}$ of NGFR \\
& $15 \mu \mathrm{g}$ & expressing vector (pINCO) \\
\hline
\end{tabular}

* Nerve Growth Factor Receptor

The electroporation resulted in about $40 \%$ of cell death. After collecting the live cells using Ficoll and culturing them for 48 hours, Magnet Assisted Cell Sorting (MACS) was carried out using antibodies against the NGFR, a membrane protein that is expressed by 


\section{Results}

the co-electroporated expression vector pINCO. It takes approximately 48 hours for sufficient NGFR to be present on the membrane of the cells for MACS.

Cells were cultured for an additional 48 hours and were then induced with doxycycline (1 $\mu \mathrm{g} / \mathrm{ml}$ ) and then the percentage of GFP positive cells was analyzed by flow cytometry. The following table shows the proportion of GFP positive cells for the different transfections:

Table. 3.2. Percentage of GFP positive cells after transfection.

\begin{tabular}{lcl}
\hline \hline Construct/Vector & \% GFP Positive & Remark \\
\hline pRTS-1-FLAG-CALM/AF10 & 20 & Result after NGFR sorting \\
\hline pRTS-1-VP16-FLAG-CALM/AF10 & 18 & Result after NGFR sorting \\
\hline pRTS-1 vector backbone & 17 & Result after NGFR sorting \\
\hline
\end{tabular}

\subsubsection{Selection/enrichment of transfected cells}

Puromycin has been used as a selection agent to enrich transfected DG-75 cells. pRTS-1 contains a gene that encodes puromycin resistance enzyme which is constitutively expressed independent of the inducible bi-directional promoter that controls the GFP and CALM/AF10. As a result, the enrichment of transfected cells can be performed without inducing the cells.

Puromycin dihydrochloride is an aminonuclease antibiotic that inhibits protein synthesis. Puromycin is used for selection and maintenance of cell lines expressing a transfected Pac gene, whose product, puromycin acetyltransferase, inactivates puromycin via acetylation. The working puromycin concentration for mammalian cell lines ranges from $1-10 \mu \mathrm{g} / \mathrm{ml}$. The selection agent needs to be titrated prior to use to determine the optimal 
concentration for the target cell line. Normally, the lowest concentration that kills $100 \%$ of non-transfected cells in 3-5 days from the start of puromycin selection at an average cell density of $6 \times 10^{4}$ cells $/ \mathrm{ml}$ is used.

Depending on individual cell type and doubling rate, the selection of stable transfectants will take between 7 and 28 days. The expansion and characterization of single cell clones will take several weeks in addition. The media should be changed every 2-3 days. This eliminates potentially toxic substances produced by dying cells and it keeps the concentration of the antibiotic at a constant level.

To calculate the concentration of puromycin to use for the enrichment of transfected DG75 cells, non-transfected DG-75 cells were seeded on a six well plate and each well was treated with one specific concentration of puromycin by following Completely Randomized Design (CRD) strategy. The position of replicates (well number) and the concentration of puromycin (treatment) applied was randomized in each plate.

The Mortality rate was estimated 5 days after treatment by counting dead/live cells after staining for Trypan blue. Appendix A1 details the result obtained, adjusting the natural mortality rate observed in control cells to 0 percent mortality (100\% survival).

Based on these results (see Appendix A5), we used a concentration of $1.24 \mu \mathrm{g} / \mathrm{ml}$ puromycin to achieve a close to $100 \%$ kill of non transfected cells within 5 days at a cell density of $6 \times 10^{4}$ cells $/ \mathrm{ml}$.

\subsubsection{Conditional expression}

Once the required dose of puromycin had been determined, the cells were put under selection at a density of $6 \times 10^{4}$ cells/ml and monitored every week for selection 


\section{Results}

efficiency. In the first 10 days, a strong enrichment of transfected cells was observed. Table 3.3 shows results obtained after 10 days selection. Cell samples were analyzed by flow cytometry 24 hours after GFP expression had been induced with doxycycline (1 $\mu \mathrm{g} / \mathrm{ml})$.

Table 3.3. Percentage of GFP positive cells after 10 days of puromycin selection

\begin{tabular}{lcl}
\hline \hline Construct/Vector & \% GFP Positive & Remark \\
\hline pRTS-1-FLAG-CALM/AF10 & 60 & $\begin{array}{l}\text { Result after 10 days puromycin } \\
\text { selection }\end{array}$ \\
\hline pRTS-1-VP16-FLAG-CALM/AF10 & & Result after 10 days puromycin \\
& 65 & selection \\
\hline pRTS-1 vector backbone & 57 & Result after 10 days puromycin \\
& & selection \\
\hline
\end{tabular}

Fluorescent microscopic observation was also carried out for the expression of GFP and visual assessment of induction. Figure 3.4 shows these observations for both the FITC (channel showing only GFP expressing cells) and phase contrast (all cells) modes. 

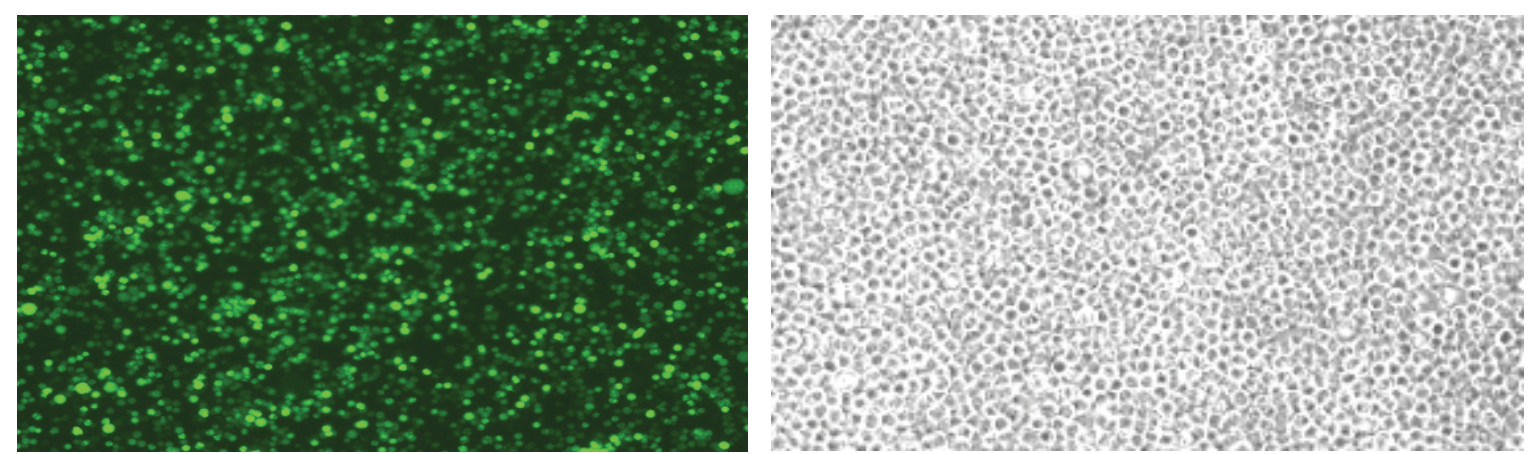

Figure 3.4. GFP expression after induction by Doxycycline. DG-75 cells expressing FLAGCALM/AF10 (from the pRTS-1-FLAG-CALM/AF10 construct) (24 hours after induction, 1 $\mu \mathrm{g} / \mathrm{ml}$ doxycycline). Left image: FITC, 20 X magnifications; Right image: No fluorescence filter, 20 X magnifications.

\subsection{RT PCR}

Once the desired percentage of GFP positive cells was obtained ( $>90 \%$, after 4 weeks of puromycin selection), the expression of CALM/AF10 was confirmed by RT-PCR.

RNA extracted from induced DG75 cells was used as a starting material. $3 \mu \mathrm{g}$ of total RNA was treated with DNaseI to remove DNA contamination. Approximately $900 \mathrm{ng}$ of DNaseI treated total RNA was used for cDNA synthesis using random primers and the protocol provided by Invitrogen (Materials and Methods section 2.2.10.2) for the Thermoscript RT-PCR kit.

A CALM/AF10 specific primer set was used to confirm the expression of CALM/AF10 after induction. The CALM/AF10 primers used were: Forward ' 5 GCAATCTTGGCATCGGAAAT-3' (Forward) and 5'-GCCTGTCGACATCCATGTTT3' (Reverse) (a schematic representation of the binding site of the primers in CALM/AF10 and the amplified fragment is shown in Figure 3.5a). The primers were designed to amplify across the breakpoint to ensure that the primers are amplifying the 
fusion gene and not the endogenous forms of either CALM or AF10. The RT-PCR amplified the expected products (Figure 3.5b).

(a)
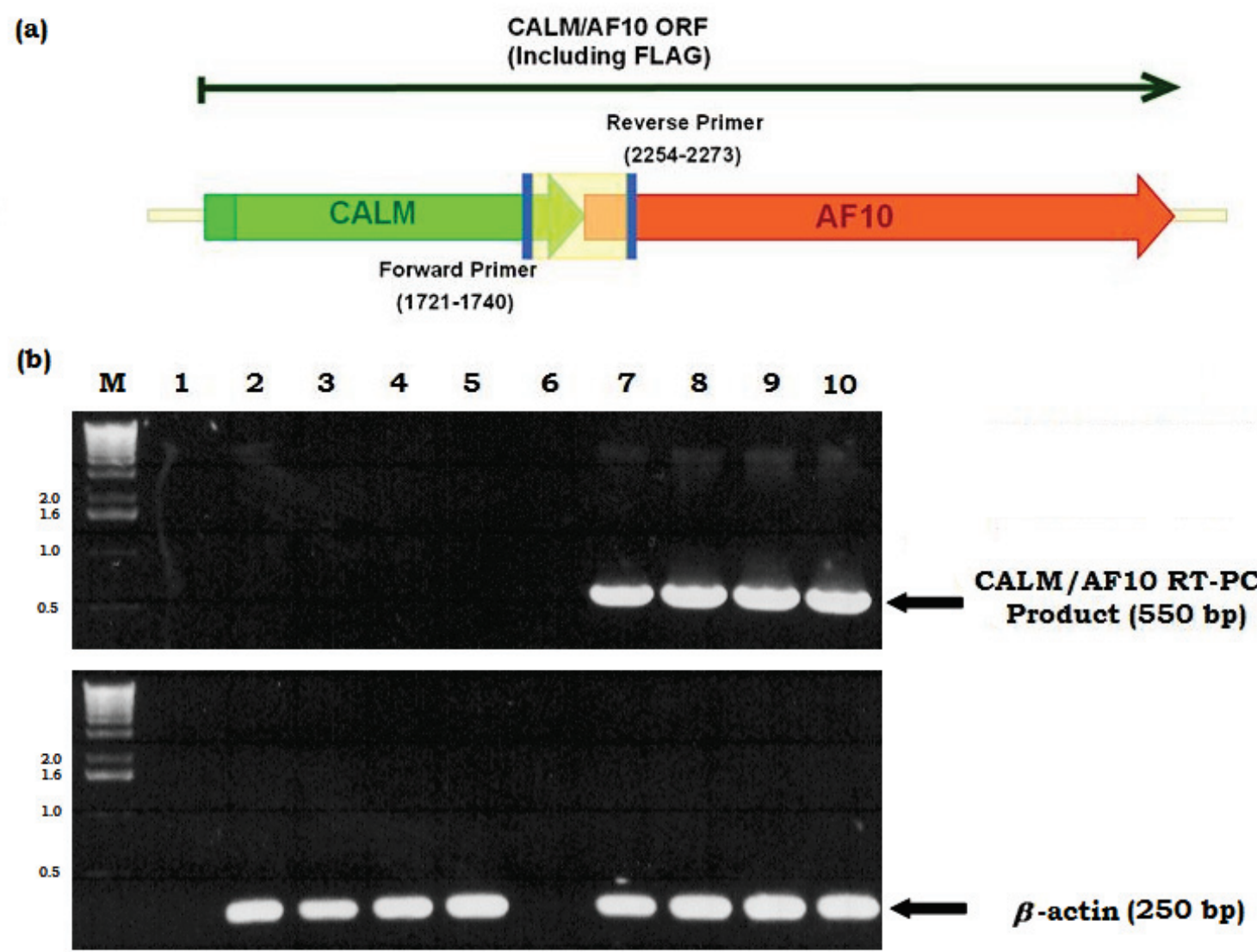

Figure 3.5. (a) Schematic representation of the binding sites of the primers used and the part of CALM/AF10 that they amplify (yellow-shaded area) (b) RT-PCR result. Lanes 1 and 6 are negative control $\left(\mathrm{H}_{2} \mathrm{O}\right)$; Lane $2=p R T S-1$ vector only control (non-induced); Lane $3=p R T S-1$ vector only control (24 hours after induction); Lane $4=p R T S-1-F L A G-C A L M / A F 10$ (noninduced); Lane 5 = pRTS-1-VP16-FLAG-CALM/AF10 (non induced); Lanes 7 and 8 are pRTS-1FLAG-CALM/AF10 (24 hours after induction); Lanes 9 and 10 are pRTS-1-VP16-FLAGCALM/AF10 (24 hours after induction). $M$ is the DNA ladder used and size markers are indicated by numbers on the left side of the gel (in kbp). 


\subsection{Microarray}

\subsubsection{Experimental Setup}

RNA samples, that were obtained from induced and non-induced cells and were confirmed for the expression of CALM/AF10 by RT-PCR, were used as a starting material for the microarray experiment.

Each sample obtained was applied to one HGU133 Plus 2.0 Affymetrix gene chip array by employing the protocol detailed in the materials and methods section. Scanned array images were finally stored as .CEL files.

\subsubsection{Low-level Analysis of Microarray Data}

\subsubsection{Preprocessing and Normalization}

Since scanned images may have different overall brightness, generally the normalization is needed to adjust the brightness of the arrays to comparable level. Currently, there are at least 6 popular algorithms that can normalize microarray data using different mathematical approaches (Millenaar et al., 2006). Recently, more methods have become available for calculating gene expression values, such as Model-Based Expression Indexes (MBEI) from $\mathrm{Li}$ and Wong ( $\mathrm{Li}$ and Wong, 2003) that are implemented in the freeware program dChip. Also available is the Robust Multiarray Average (RMA) software from Irizarry et al. (Irizarry et al., 2003). In contrast to MAS 5.0 or GCOS, in which information from only one microarray is used, model-based algorithms incorporate information from multiple microarrays to calculate the expression of a gene. The probe response pattern is fitted over multiple arrays with a multiplicative model in dChip and an additive model in the RMA software. These algorithms use the fitted models to detect abnormally behaving probes, which are subsequently excluded for calculating gene 


\section{Results}

expression. Therefore, gene expression from these model-based algorithms can be expected to provide more reproducible results. Both dChip and RMA use a stochastic model to estimate gene expression.

\subsubsection{Median Probe Intensity (MPI) and background Adjustment}

dChip (Li and Wong, 2003), a freely available software (http://biosun1.harvard.edu/complab/dchip/), was used to perform the normalization of the microarray data obtained. dChip normalizes arrays at the Perfect Match (probes matching perfectly to a certain part of the reference mRNA, PM) and Mismatch (probes containing a single mismatch, MM) (see figure 2.2a) probe level before computing model-based expression levels. Model-based method assumes that the arrays are already at comparable brightness ( $\mathrm{Li}$ and Wong, 2003). However, there is also a danger of introducing artifacts if normalization is not done reasonably. To avoid the introduction of artifacts, one can examine the normalization curve and, if the amplification and scanning steps are controlled well and if the median intensities of arrays are close $( \pm 5$ Median Probe Intensity (MPI) from the median array), one may skip the normalization step and perform a model-based expression analysis directly ( $\mathrm{Li}$ and Wong, 2003). It is very critical that a visual inspection of the array images is performed before further analysis is carried out to rule out artifacts.

Table 3.4 summarizes the names of the arrays and the median intensities obtained for the arrays in this study. After the calculation of the Median Probe Intensities (MPI), it was observed that the array with median intensity (taking all the nine arrays together) was pRTS-1-FLAG-CALM/AF10 24hrs (MPI = 80). This array was then used as a baseline for the normalization of the remaining 8 arrays, a process by which the brightness of each 
array is adjusted to approximate the MPI of the baseline array. The adjusted MPI values are given in Table 3.4 .

Table 3.4. Arrays and their Median Probe Intensity (MPI)

\begin{tabular}{|c|c|c|c|}
\hline \multirow[t]{2}{*}{ Name of Array } & \multicolumn{2}{|c|}{ Median Probe Intensity (Brightness) } & \multirow[t]{2}{*}{ Remark } \\
\hline & Before Adjustment & After Adjustment & \\
\hline pRTS-1 0hrs & 78 & 80 & $\begin{array}{l}\text { Sample from DG-75 transfected with } \\
\text { the empty pRTS-1 vector (non- } \\
\text { induced) }\end{array}$ \\
\hline pRTS-1 24hrs & 78 & 81 & $\begin{array}{l}\text { Sample from DG-75 transfected with } \\
\text { the empty pRTS-1 vector ( } 24 \text { hours } \\
\text { after induction) }\end{array}$ \\
\hline pRTS-1 72hrs & 98 & 80 & $\begin{array}{l}\text { Sample from DG-75 transfected with } \\
\text { the empty pRTS-1 vector ( } 72 \text { hours } \\
\text { after induction) }\end{array}$ \\
\hline $\begin{array}{l}\text { pRTS-1-VP16-FLAG- } \\
\text { CALM/AF10 0hrs }\end{array}$ & 95 & 80 & $\begin{array}{l}\text { Sample from DG-75 transfected with } \\
\text { the VP16-FLAG-CALM/AF10-pRTS-1 } \\
\text { construct (non-induced) }\end{array}$ \\
\hline $\begin{array}{l}\text { pRTS-1-VP16-FLAG- } \\
\text { CALM/AF10 } 24 \text { hrs }\end{array}$ & 70 & 80 & $\begin{array}{l}\text { Sample from DG-75 transfected with } \\
\text { the VP16-FLAG-CALM/AF10-pRTS-1 } \\
\text { construct ( } 24 \text { hours after induction) }\end{array}$ \\
\hline $\begin{array}{l}\text { pRTS-1-VP16-FLAG- } \\
\text { CALM/AF10 72hrs }\end{array}$ & 85 & 80 & $\begin{array}{l}\text { Sample from DG-75 transfected with } \\
\text { the VP16-FLAG-CALM/AF10-pRTS-1 } \\
\text { construct (72 hours after induction) }\end{array}$ \\
\hline $\begin{array}{l}\text { pRTS-1- FLAG- } \\
\text { CALM/AF10 0hrs }\end{array}$ & 82 & 81 & $\begin{array}{l}\text { Sample from DG-75 transfected with } \\
\text { the FLAG-CALM/AF10-pRTS-1 } \\
\text { construct (non-induced) }\end{array}$ \\
\hline
\end{tabular}




\section{Results}

\begin{tabular}{lll}
\hline $\begin{array}{l}\text { pRTS-1- FLAG- } \\
\text { CALM/AF10 24hrs }\end{array}$ & 80 & $\begin{array}{l}\text { Sample from DG-75 transfected with } \\
\text { the FLAG-CALM/AF10-pRTS-1 }\end{array}$ \\
& & construct (24 hours after induction) \\
& & NB: median Brightness across arrays \\
\hline pRTS-1- FLAG- & 77 & Sample from DG-75 transfected with \\
CALM/AF10 72hrs & 79 & $\begin{array}{l}\text { the FLAG-CALM/AF10-pRTS-1 } \\
\text { construct (24 hours after induction) }\end{array}$ \\
\hline
\end{tabular}

\subsubsection{The Invariant Set Normalization}

The Invariant Set Normalization method chooses a subset of PM probes with small within-subset rank difference in the two arrays, to serve as the basis for fitting a normalization curve ( $\mathrm{Li}$ and Wong, 2001). The image of outliers (array and single outliers) identified through model-fitting can be used to assess the quality of an experiment and to identify unexpected problems such as misaligned corner of a DAT file (Li and Wong, 2001).

The fitted curve is the running median curve in the scatterplot of probe intensities of two arrays (with the baseline array on the Y-axis and the array to be normalized on the Xaxis). When fitting the running median curve at the two ends, $5 \%$ of the "invariant" points are used to fit a ray at one end fixed; this makes the high-end normalization relationship more smooth and robust. The final running median curve is a piece-wise linear curve ( $\mathrm{Li}$ and Wong, 2001). Then the normalization transformation is performed for all the points (probes) in the array on the $\mathrm{X}$-axis (the $\mathrm{Y}$-axis is the baseline array and is not changed). To obtain the normalized value of a point which has a particular intensity value on the $\mathrm{X}$-axis, we drop an imagined vertical line passing this point, and use the Y- 
axis value of the intersection point of this line and the fitted curve as the normalized value. The normalized probe values beyond the range $[0,65535]$ are truncated at the boundaries. The total effect of the normalization is a rotation and straightening of the scatter plot, so it better centers around the diagonal line $\mathrm{y}=\mathrm{x}$ ( $\mathrm{Li}$ and Wong, 2001). Figure 3.6 gives an example of an invariant set normalization carried out on pRTS-1 0hrs by using the baseline array pRTS-1-FLAG-CALM/AF10 24hrs. 
(a)

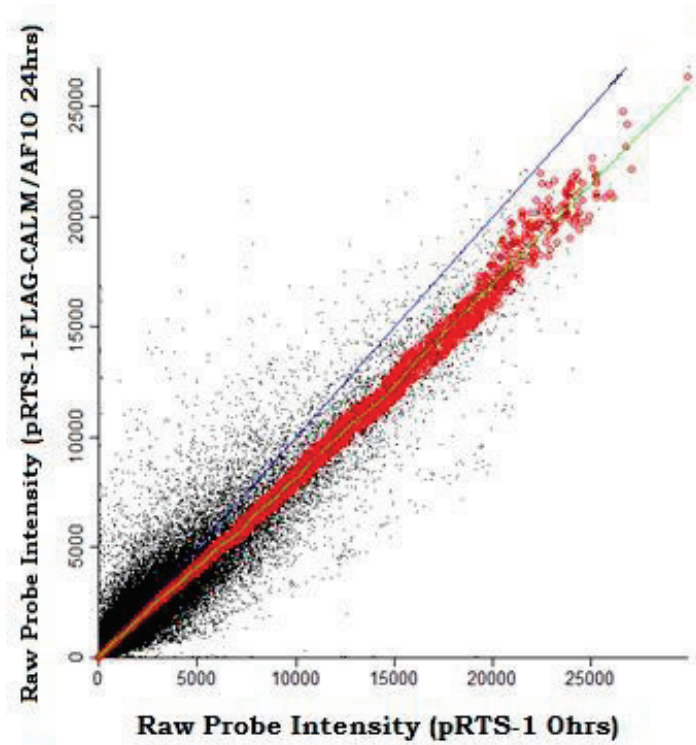

(b)

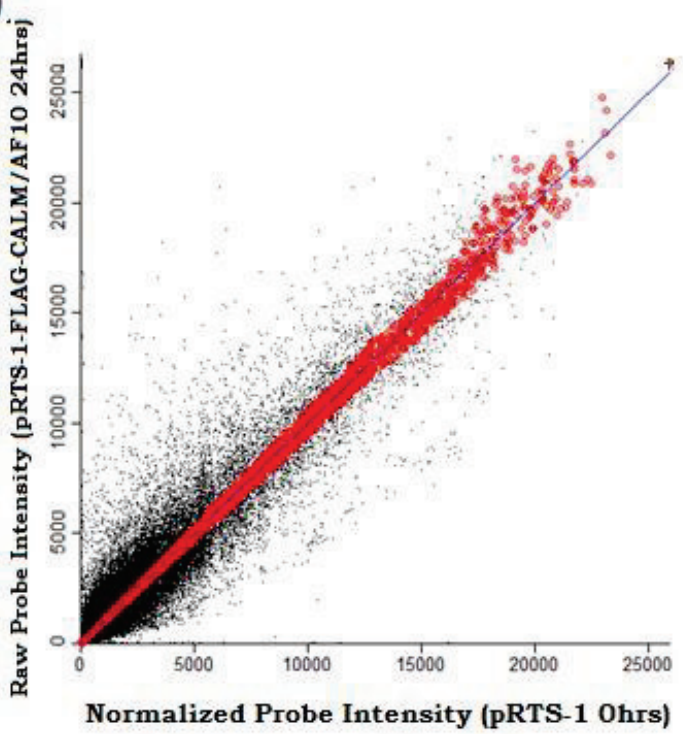

Figure 3.6. Example of Invariant set normalization (pRTS-1 Ohrs versus pRTS-1-FLAGCALM/AF10 24hrs). Y axes represent the base line array (pRTS-1-FLAG-CALM/AF10 24hrs) and $X$ axes represent the array to be normalized (pRTS-1 Ohrs in this case). Each black point indicates a probe intensity value. (a) Scatterplot of raw intensities as read by the Affymetrix array scanner. The invariant set (5\% of the points that are used to fit a ray that is fixed at one end) are indicated in red circles. Blue indicated fitted function $y=x$ ( $y$ equals to the raw intensity of the baseline array, pRTS-1-FLAG-CALM/AF10 24hrs). The green line represents the line that best describes the correlation of raw probe intensities of the base line array (pRTS-1FLAG-CALM/AF10 24hrs)and the array to be normalized(pRTS-1 Ohrs) (correlation coefficient $r=0.957$ ). (b) Normalized probe intensities. The probe intensities of the array to be normalized ( $p R T S-1$ Ohrs) are rotated to fit into the function $y=x$ (by rotating the green line to fit the blue line) without changing the values of the base line (pRTS-1-FLAG-CALM/AF10 24hrs) probe intensities.

All the other arrays were normalized in a similar fashion by taking the pRTS-1-FLAGCALM/AF10 24hrs array as a base line array.

\subsubsection{High-level analysis}

\subsubsection{Sample comparison (t-test)}

Given two samples or two groups of samples, we want to identify genes that are reliably differentially expressed between the two groups. This is done for every gene in the array and is based on calculating a t-statistic. The t-statistic tries to account for the level of difference in 
expression of a given probe set in two different samples and determines if this difference is statistically significant (Li and Wong, 2003).

Based on the t-test comparison of the different samples, various comparisons were carried out to find genes that are significantly differentially regulated at a confidence interval of $95 \%$. The comparison was done by comparing the expression level of a probeset of a given gene in the experimental setting versus the expression level of the same probeset in the control setting. For instance, to find the genes that were at least 2 fold significantly differentially regulated (up or down) in the sample pRTS-1-FLAGCALM/AF10 $24 \mathrm{hrs}$ (genes that were deregulated 24 hours after CALM/AF10 expression), the pRTS-1-FLAG-CALM/AF10 24 hrs array was compared to the pRTS-1FLAG-CALM/AF10 0hrs (no CALM/AF10 expression) control. This list of differentially regulated genes was further subjected to other controls; genes that were also found to be 2 fold differentially regulated in the following comparisons were excluded from the final list,

a. pRTS-1-FLAG-CALM/AF10 0hrs to pRTS-1 0hrs (to exclude genes that were already 2 fold up or down-regulated without induction)

b. pRTS-1 24 hrs to pRTS-1 0hrs (to exclude genes that were deregulated because of confounding factors like GFP expression or addition of doxycycline)

Table 3.5 gives the number of genes that were found to be at least 2 fold significantly differentially regulated (up or down regulated) for different comparisons upon the expression of CALM/AF10. The genes that have fulfilled the selection criteria and test 


\section{Results}

statistics for were also evaluated by plotting them in an M (Intensity Ratio)-A (Average

Intensity) plot (Figure 3.7).

Table 3.5. Number of differentially regulated genes in different comparisons.

\begin{tabular}{|c|c|c|c|}
\hline $\begin{array}{c}\text { Comparison } \\
\text { number }\end{array}$ & Experiment & Baseline & $\begin{array}{c}\text { Number of } \\
\text { genes }\end{array}$ \\
\hline 1 & pRTS-1-FLAG-CALM/AF10 24 hrs & $\begin{array}{l}\text { pRTS-1 Ohrs, pRTS-1-FLAG- } \\
\text { CALM/AF10 0hrs, pRTS-1 } 24 \text { hrs }\end{array}$ & 1237 \\
\hline 2 & pRTS-1-FLAG-CALM/AF10 72 hrs & $\begin{array}{l}\text { pRTS-1 Ohrs, pRTS-1-FLAG- } \\
\text { CALM/AF10 Ohrs, pRTS-1 } 72 \text { hrs }\end{array}$ & 564 \\
\hline 3 & $\begin{array}{l}\text { pRTS-1-VP16-FLAG-CALM/AF10 } 24 \\
\text { hrs }\end{array}$ & $\begin{array}{l}\text { pRTS-1 Ohrs, pRTS-1-VP16- } \\
\text { FLAG-CALM/AF10 0hrs, pRTS-1 } \\
24 \text { hrs }\end{array}$ & 990 \\
\hline 4 & $\begin{array}{l}\text { pRTS-1-VP16-FLAG-CALM/AF10 } 72 \\
\text { hrs }\end{array}$ & $\begin{array}{l}\text { pRTS-1 Ohrs, pRTS-1-VP16- } \\
\text { FLAG-CALM/AF10 0hrs, pRTS-1 } \\
72 \text { hrs }\end{array}$ & 164 \\
\hline 5 & $\begin{array}{l}\text { pRTS-1-FLAG-CALM/AF10 24hrs and } \\
\text { pRTS-1-FLAG-CALM/AF10 } 72 \mathrm{hrs}\end{array}$ & $\begin{array}{l}\text { pRTS-1 Ohrs, pRTS-1-FLAG- } \\
\text { CALM/AF10 Ohrs, pRTS-1 } 24 \text { hrs, } \\
\text { pRTS-1 } 72 \text { hrs }\end{array}$ & 477 \\
\hline 6 & $\begin{array}{l}\text { pRTS-1-VP16-FLAG-CALM/AF10 24hrs } \\
\text { and pRTS-1-VP16-FLAG-CALM/AF10 } \\
72 \mathrm{hrs)}\end{array}$ & $\begin{array}{l}\text { pRTS-1 0hrs, pRTS-1-VP16- } \\
\text { FLAG-CALM/AF10 0hrs, pRTS-1 } \\
24 \text { hrs, pRTS-1 } 72 \text { hrs }\end{array}$ & 130 \\
\hline
\end{tabular}




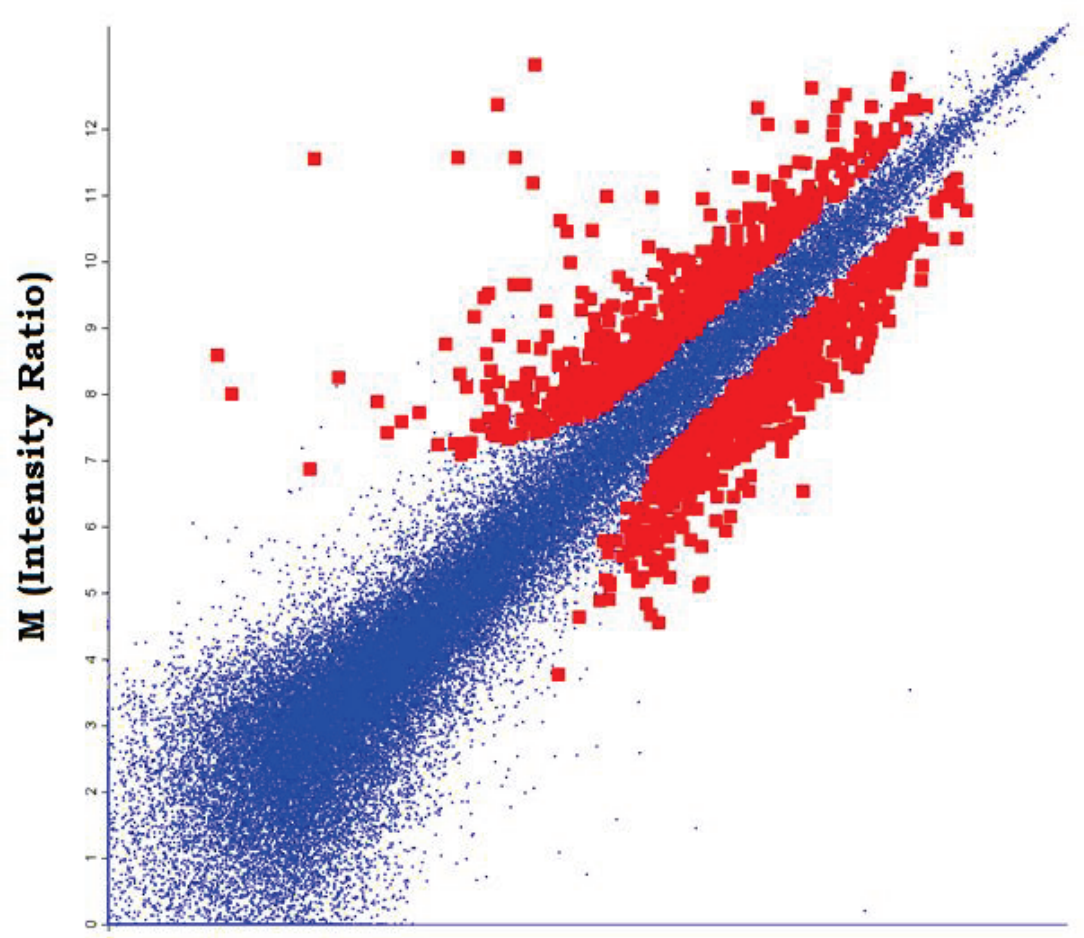

A (Average Intensity)

Figure3.7. M-A plot for identification of genes that are 2 fold differentially regulated in $p R T S$ 1-FLAG-CALM/AF10 24hrs. M (y axis) is the intensity ratio given by the log2 difference of the experimental sample (pRTS-1-FLAG-CALM/AF10 24hrs) and control (pRTS-1 0hrs, pRTS-1FLAG-CALM/AF10 Ohrs, and pRTS-1 24hrs)(see text for explanation on how the comparison criteria is setup), and it is of the form $M=\log _{2} E-\log _{2} C$, where $E$ is experimental sample and $C$ is control. $A(y=x$ line) is the average intensity for a probeset in the plot and is calculated using the formula $A=1 / 2\left(\log _{2} E+\log _{2} C\right)$, where $E$ and $C$ are experimental expression level and control expression level, respectively. Red squares are probeset that satisfied the selection criteria (up and down-regulated) and blue dots are probesets that are not differentially regulated.

\subsubsection{The effect of the VP16 transactivating domain}

The VP16 transactivating domain is a strong transactivating domain which is able to transactivate almost all promoter types. We speculated that CALM/AF10 might act as a transcriptional repressor on certain promoters. However, due to limitations inherent in our experimental set-up (e.g. not $100 \%$ of cells transfected), weakly down-regulated genes would be more difficult to identify. To circumvent this problem, we fused the VP16 transactivation domain to the CALM/AF10 fusion protein in order to convert CALM/AF10 from a transcriptional repressor into a strong transcriptional activator of 


\section{Results}

these promoters thus leading to a clear detection of genes that would be normally downregulated by CALM/AF10.

To assess whether VP16 had the expected effect, the list of genes that were found to be differentially regulated in pRTS-1-FLAG-CALM/AF10 24hrs and pRTS-1-FLAG CALM/AF10 72hrs (Table 3.5, $5^{\text {th }}$ comparison, 477 genes) were compared to the list of differentially regulated genes in pRTS-1-VP16-FLAG-CALM/AF10 24hrs and pRTS-1VP16-FLAG CALM/AF10 72hrs (Table $3.5,6^{\text {th }}$ comparison, 130 genes). It was observed that 95 of the 130 genes that were differentially regulated in pRTS-1-VP16-FLAGCALM/AF10 24hrs and pRTS-1-VP16-FLAG-CALM/AF10 72hrs (VP16-CALM/AF10 expressing cells) were also differentially regulated in pRTS-1-FLAG-CALM/AF10 24hrs and pRTS-1-FLAG CALM/AF10 72hrs (CALM/AF10 expressing cells but without VP16). A Pearson correlation was used to evaluate whether the differential expression levels of these genes in these settings were comparable. The correlation analysis showed that there was a statistically significant correlation between the differential expression levels of genes in VP16-CALM/AF10 expressing cells and CALM/AF10 expressing cells but without VP16 ( $\mathrm{r}=0.959, \mathrm{p} \approx 0.00)$ (Table 3.6 and figure 3.8$)$. In conclusion, the VP16 transactivating domain did not enhance genes that were found to be down-regulated in the pRTS-1-FLAG-CALM/AF10 (pRTS-1-FLAG-CALM/AF10 24hrs and pRTS-1FLAG CALM/AF10 72hrs) to control (pRTS-1 0hrs, pRTS-1-FLAG-CALM/AF10 0hrs, pRTS-1 24hrs, and pRTS-1 72hrs) comparison. 
Table 3.6. Correlation table comparing differential expression levels of VP16-CALM/AF10 expressing cells (pRTS-1-VP16-FLAG-CALM/AF10 24hrs and pRTS-1-VP16-FLAG-CALM/AF10 72hrs) and CALM/AF10 expressing cells but without VP16 (pRTS-1-FLAG-CALM/AF10 24hrs and pRTS-1-FLAG CALM/AF10 72hrs).

\begin{tabular}{llr}
\hline \hline All time points taken together & CALM/AF10 \\
& & $\begin{array}{l}\text { expressing cells but } \\
\text { without VP16 }\end{array}$ \\
\hline VP16-CALM/AF10 expressing cells & Pearson Correlation & $.959{\left({ }^{* *}\right)}^{.000}$ \\
\hline & Sig. (2-tailed) & .005 \\
\hline$N$ & 95 \\
\hline
\end{tabular}

${ }^{* *}$ Correlation is significant at the 0.01 level (2-tailed).

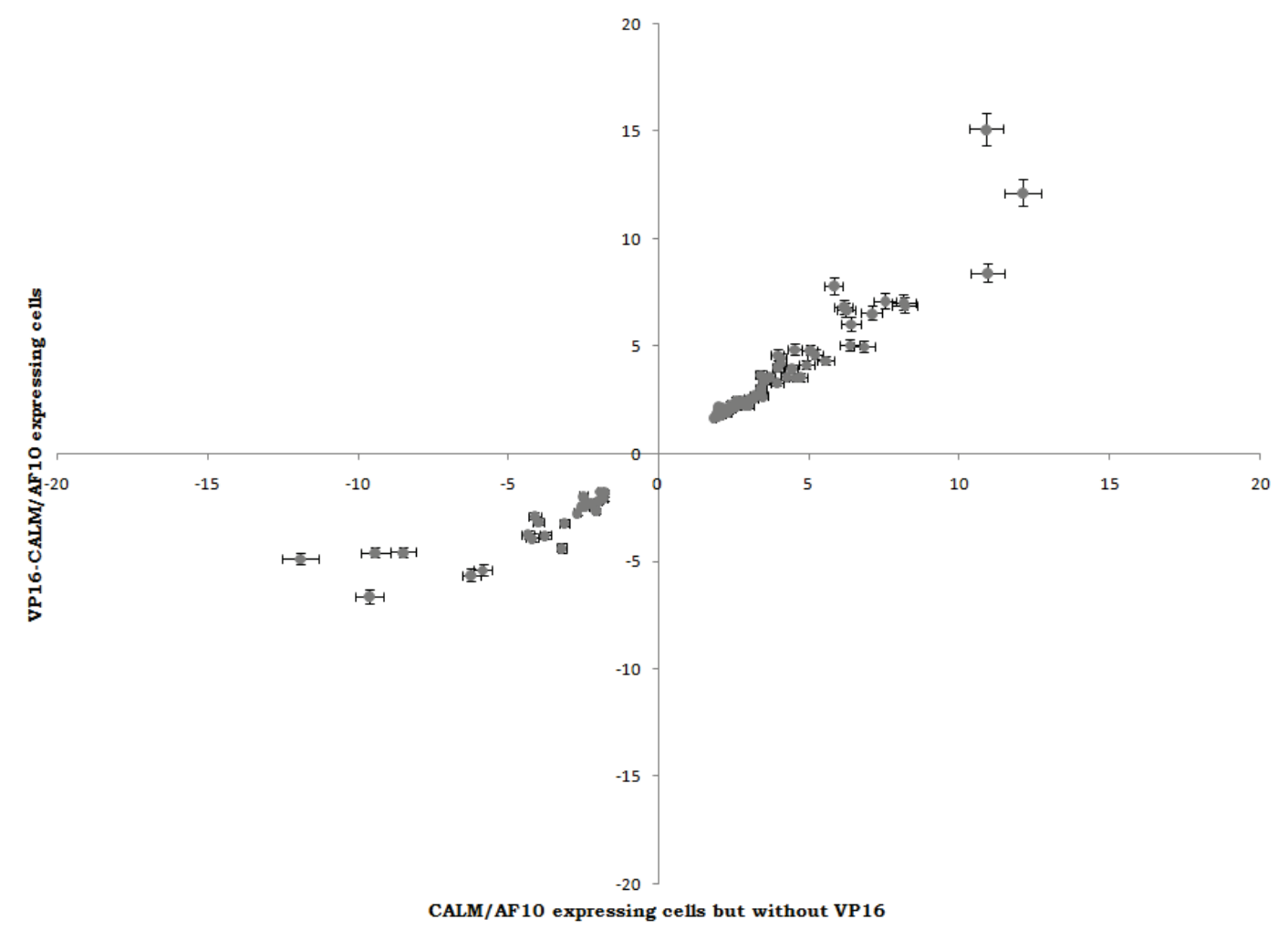

Figure 3.8. Scatterplot showing fold expression levels of the 95 genes that were found to be differentially regulated in both VP16-CALM/AF10 expressing cells ( $p R T S-1-V P 16-F L A G-$ CALM/AF10 24hrs and pRTS-1-VP16-FLAG-CALM/AF10 72hrs, y axis) and CALM/AF10 expressing cells but without VP16 (pRTS-1-FLAG-CALM/AF10 24hrs and pRTS-1-FLAG CALM/AF10 72hrs, $x$ axis). Error bars indicate the 95\% confidence interval. 


\section{Results}

\subsubsection{Hierarchical clustering}

Given a set of items to be clustered (items can be either genes or chips/experiments), agglomerative hierarchical clustering (HC) recursively merges items with similar items, or with the result of previous merges, according to their pair-wise distance (with the closest item pairs being merged first) (Gould, 2005). The purpose of this method is to group together genes that behave in a similar fashion in a certain set of experiment. As a result, it produces a tree structure, referred to as dendrogram, whose nodes correspond to:

i) The original items (these are the leaves of the tree); and

ii) The merging of other nodes (these are the internal nodes of the tree)

Different distance measures can give different clustering results. The most common types of distance measurement depend on either correlation (parametric or non-parametric) or Euclidean distance (parametric) measurement. Once the distance between different genes is computed depending on how they behave in different samples, there are various ways of building the hierarchy/linkage:

Single linkage - minimum distance between points in different clusters

Complete linkage - maximum distance

Average linkage - mean of all distances between points in different clusters

Centroid distance - represent each cluster by its centroid and measures distances between them.

Based on the results obtained from the differential gene expression by comparing different samples, hierarchical clustering was performed using Euclidean distance as a measure of similarity/dissimilarity of genes in their expression pattern and Average linkage as a hierarchical amalgamation rule. 
Figure 3.9 shows heatmaps of some selected genes based on the list of differentially regulated genes obtained by comparing CALM/AF10 expressing cells (pRTS-1-FLAGCALM/AF10 24hrs and pRTS-1-FLAG-CALM/AF10 $72 \mathrm{hrs)} \mathrm{to} \mathrm{the} \mathrm{controls} \mathrm{(pRTS-1}$ 0hrs, pRTS-1-FLAG-CALM/AF10 0hrs, pRTS-1 24 hrs, pRTS-1 72 hrs) (comparison 5 in table 3.5, 477 genes). The genes in figure 3.9 have been selected because the pathways that they are involved in were later found to be some of the strongly deregulated cellular processes in this study and are relevant for subsequent discussion. It can be observed that the selected genes shown here are mostly down-regulated after CALM/AF10 expression. Genes close to each other based on the hierarchy show a similar expression pattern indicating that they might be co-regulated by an upstream factor or that they are regulating each other. 
(a)

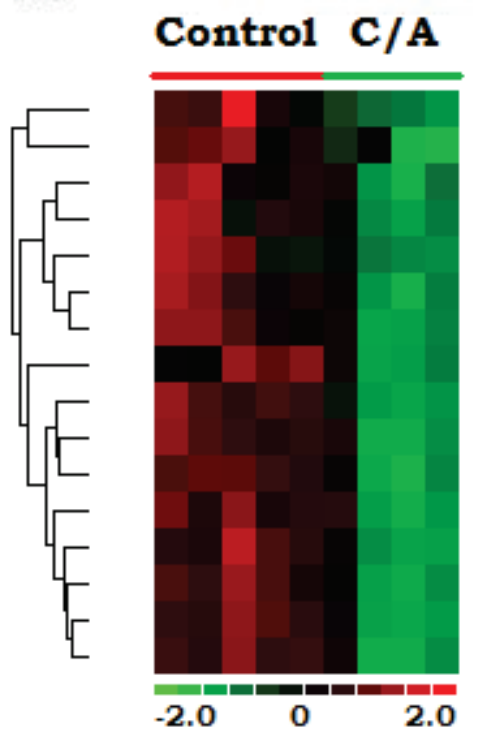

(b)

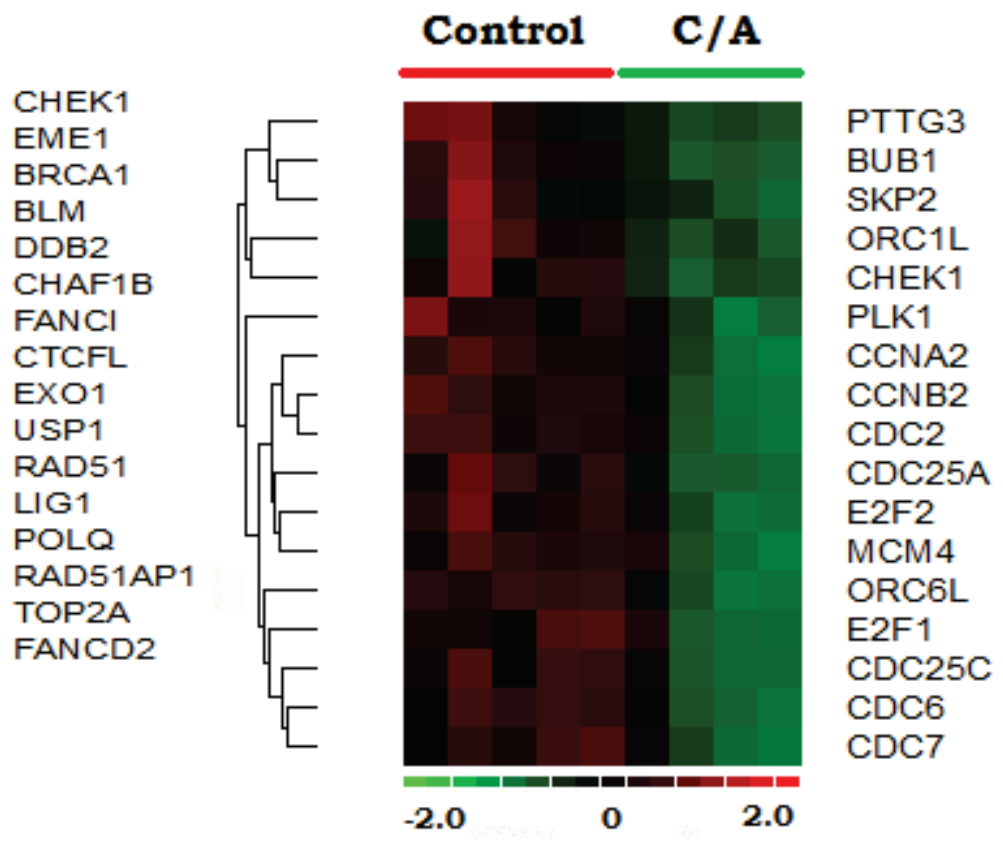

Figure 3.9. Hierarchical clustering of differentially regulated genes obtained by comparing CALM/AF10 expressing cells (pRTS-1-FLAG-CALM/AF10 24hrs and pRTS-1-FLAG-CALM/AF10 $72 \mathrm{hrs}$ ) to the controls (pRTS-1 Ohrs, pRTS-1-FLAG-CALM/AF10 Ohrs, pRTS-1 24 hrs, pRTS-1 $72 \mathrm{hrs}$ ). C/A stands for cells expressing DG-75 (pRTS-1-FLAG-CALM/AF10 24hrs, pRTS-1FLAG-CALM/AF10 72 hrs, pRTS-1-VP16-FLAG-CALM/AF10 24hrs, and pRTS-1-VP16-FLAGCALM/AF10 $72 \mathrm{hrs}$ ) and Control stands for non-induced DG-75 cells containing CALM/AF10 constructs (pRTS-1-FLAG-CALM/AF10 Ohrs and pRTS-1-VP16-FLAG-CALM/AF10 Ohrs) and vector only controls ( $p R T S-1$ Ohrs, $p R T S-124 h r s$, and pRTS-1 72hrs). These genes are involved in DNA repair (a) and cell cycle (b). Red squares indicate up-regulation and green squares show down-regulated (color scale is shown under the heatmaps). The hierarchy is shown on the left side of the heatmaps and gene names are given on the right side.

\subsubsection{Principal Component Analysis}

In Affymetrix ${ }^{\circledR}$ based microarray studies each sample is represented by one chip. Each chip will thus have a unique expression pattern (snapshot of the expression status of every gene within the cell at the time of sample preparation) if all the genes on the chip are simultaneously considered. This is of biological interest as the physiology of a cell at a given time is the result of the interplay of the expression levels of the various genes in the cell. The more similar two samples are biologically, the higher is the similarity in 
their expression pattern. As a single microarray chip covers the entire human genome (more than 20,000 genes interrogated by more than 54,000 probesets in the HGU133plus 2.0 chip), it is usually impractical to assess every gene independently and see how its expression contributes to the different expression patterns that are displayed by the different samples. To assess this biological variability among the different samples and find a statistical method that would summarize this variation has always been one of the key challenges in the analyses of microarray data. Towards this end, the principal component analysis has been used extensively in numerous microarray studies.

The principal component analysis (PCA) is a statistical method that tries to find few functions (usually 3, referred to as Eigenvectors or principal components) that best explain the variation that is observed in a dataset by reducing the number of variables (gene expression levels in this case) based on how strong their correlation or co-variation is. This is achieved by grouping genes that vary in their expression in a similar fashion across different samples into one function that captures their expression pattern. The power of a PCA is thus dependent on how highly correlated or co-varied the genes are: the lower the correlation the harder it is to find a small number of principal components that could explain the variation observed in the data set.

In the current study, the R implementation of PCA (pcaMethods) was used to conduct a principal component analysis on the 9 normalized microarrays (R version 2.8.1 (2008-1222), Copyright $(\mathrm{C}$ 2008, The $\mathrm{R}$ Foundation for Statistical Computing). 3 principal components were extracted that explained cumulatively $98.42 \%$ of the variation among the 9 different samples (see table 3.7 for further details). Based on these 3 principal components (PCs), new values are calculated for the expression level of each gene (factor 


\section{Results}

loading). Based on the loadings, a 3D scatterplot of the samples was generated that showed which of the samples are more similar/different depending on the position of the samples in the $3 \mathrm{D}$ space, by giving most weight to the principal component 1 (PC1) axis, followed by PC2 and PC3 based on their contribution to the explanation of the variation (Figure 3.10).

Table 3.7. PCA result. The second (\% total variance) and the last column (Cumulative \% of variance) are of particular interest in this table.

\begin{tabular}{lllll}
\hline \hline PCA & Eigenvalue & \% Total variance & Cumulative Eigenvalue & Cumulative \% \\
\hline $\mathbf{1}$ & 6.163022 & 68.47803 & 6.163022 & 68.47803 \\
\hline $\mathbf{2}$ & 2.406050 & 26.73389 & 8.569073 & 95.21192 \\
\hline $\mathbf{3}$ & 0.289115 & 3.21239 & 8.858188 & 98.42431 \\
\hline
\end{tabular}

It can be observed (figure 3.10) that the CALM/AF10 and VP16-CALM/AF10 expressing samples (pRTS-1-VP16-FLAG-CALM/AF10 24hrs, pRTS-1-VP16-FLAG CALM/AF10 72hrs, pRTS-1-FLAG-CALM/AF10 24hrs, and pRTS-1-FLAGCALM/AF10 72hrs) cluster together, with slight deviation for the VP16-CALM/AF10 expressing sample at $72 \mathrm{hrs}$ (pRTS-1-VP16-FLAG-CALM/AF10 72hrs). Samples with CALM/AF10 or VP16-CALM/AF10 expression plasmids which are not induced (pRTS1-VP16-FLAG-CALM/AF10 0hrs and pRTS-1-FLAG-CALM/AF10 0hrs) and the vector only controls (pRTS-1 0hrs, pRTS-1 24hrs, and pRTS-1 72hrs) form a cluster as well. This is as expected because cells that are not induced (i.e. not expressing CALM/AF10 or 
VP16-CALM/AF10) should have a gene expression pattern which is similar to the vector only controls (pRTS-1 0hrs, pRTS-1 24hrs and pRTS-1 72hrs). 


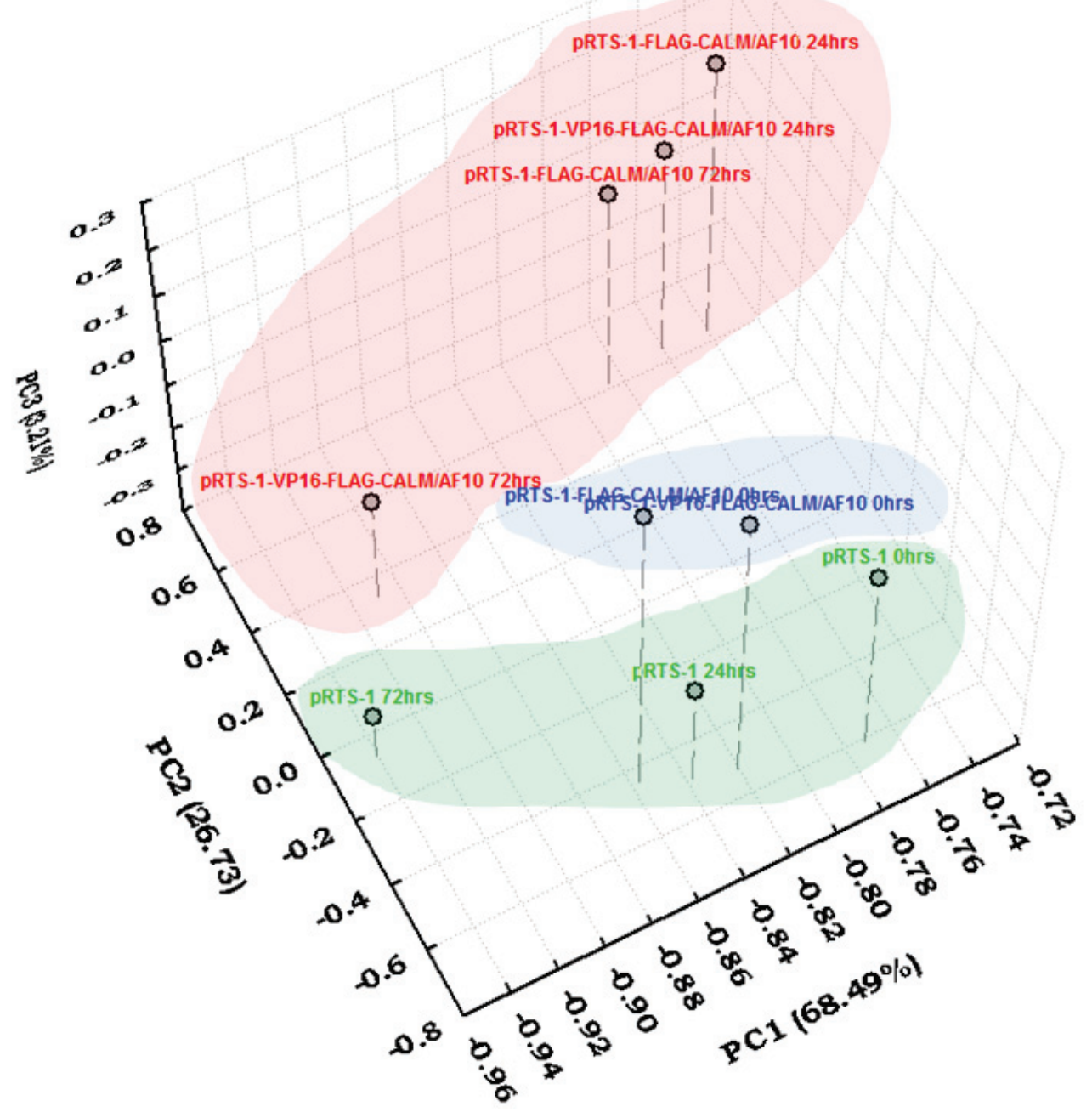

Figure 3.10. 3D scatterplot of the samples with respect to the 3 principal components. Dots represent samples and spikes show the position of the samples on a 2D surface of PC1 and PC2 (PC1 and PC2 together explained 95\% of the variance). Red labels (and red-shaded area) are all samples that were induced to express CALM/AF10 (pRTS-1-VP16-FLAG-CALM/AF10 24hrs, pRTS-1-VP16-FLAG CALM/AF10 72, pRTS-1-FLAG-CALM/AF10 24hrs, and pRTS-1-FLAG-CALM/AF10 72hrs). Blue labels and shading represent non-induced experimental samples (pRTS-1-VP16-FLAG-CALM/AF10 Ohrs and pRTS-1-FLAG$C A L M / A F 10$ Ohrs). Green labeling and shading show vector only controls (pRTS-1 0hrs, pRTS-1 24hrs, and pRTS-1 72hrs). NB: shades only show sample classification and not necessarily clustering. 


\subsubsection{Chromosomal distribution of differentially regulated genes}

One of the interesting ways to look at microarray data is to examine the global transcriptional consequence by plotting the differentially expressed genes according to their chromosomal location. The main objective would be to look at interesting chromosomal locations or positions that might be significantly affected. This might be an indication of positional co-regulation of groups of genes.

\subsubsection{1. dChip based analysis of chromosomal distribution of differentially regulated} genes

The dChip software can plot the differentially regulated genes according to their location in the genome. The genes are assigned to their location on the chromosome and are indicated by red (up-regulated) or green (down-regulated) bars. The position of a bar with respect to the middle line indicates the direction of transcription: if the bar is above the middle line it indicates that the gene is transcribed from the sense strand and if it is below the middle line it shows that the gene is transcribed from the anti-sense strand. The genes on each chromosome are placed proportionally from chromosomal position 0 to the gene with the maximal chromosomal position in the Genome information file. The test is carried out at a cut point of $500 \mathrm{kbp}$ of a stretch of a chromosome on either side of a differentially regulated gene with respect to its transcription start site. The p-values are calculated for all stretches containing less or equal to 20 differentially regulated genes to assess the significance of "gene proximity". It is an evaluation of the "tightness" (the rank distance of the genes on the two ends of the stretch, in Mbp) of a stretch of $n$ genes (real gene distribution) against that of $n$ genes randomly put on the chromosome (relative position of genes along the chromosome if they were randomly distributed). This way, 


\section{Results}

gene density along a chromosome will be taken into account. For example, on chromosome 6 , the stretch from gene 1 to 9 has a p-value 0.021799 , indicating that this stretch of chromosome is gene rich as a p-value of 0.021799 is significant and rejects the hypothesis that genes are randomly distributed along a chromosome. These significant gene stretches are outlined in blue boxes. If a significant longer stretch contains a significant shorter stretch, only the longer one is reported and outlined. Since there is no correction for multiple hypotheses testing, the p-values here are used for drawing attention to specific genes.

In the current study, the list of differentially regulated genes obtained by comparing pRTS-1-FLAG-CALM/AF10 expressing cells (pRTS-1-FLAG-CALM/AF10 24hrs and pRTS-1-FLAG-CALM/AF10 72hrs) versus controls (pRTS-1 0hrs, pRTS-1-FLAGCALM/AF10 0hrs, pRTS-1 24 hrs, pRTS-1 72 hrs, comparison criterion 5 in table 3.5) was used to generate figure 3.11. It can be observed that there are a number of significant cluster of differentially regulated genes, as indicated by the blue bars/boxes. Each region can be further investigated by examining the differentially regulated genes. For instance, chromosome 10 is interesting as it is:

a. The chromosome that contains one of the fusion partners of CALM, namely AF10 and

b. Previous work by our group on patient microarray data that compared 10 $\mathrm{CALM} / \mathrm{AF} 10^{+} \mathrm{AML}$ and ALL patients to 119 cases of other leukemias (CML, ALL with $1 ; 19$ or $4 ; 11$, ALL with MLL rearrangement, ALL, ALL with $\mathrm{Ph}+$, AML with MLL rearrangement, AML normal karyotype, AML normal karyotype FLT3+, AML with inv(16), AML with $\mathrm{t}(8 ; 21)$, AML with $\mathrm{t}(15 ; 17)$, AML with 
complex karyotype; all with 10 samples each except ALL with MLL rearrangement (9)) and to 10 normal bone marrow samples showed that genes located close to the breakpoint of the $\mathrm{t}(10 ; 11)(\mathrm{p} 12 ; \mathrm{q} 14)$ translocation on $10 \mathrm{p} 12$ (COMMD3, SPAG6, BMI and DNAJC1) were found to be at least 1.5 fold differentially regulated (unpublished data). To see if such an effect is also observable in our model, we examined chromosome 10 more closely in the next section. 


\section{Results}

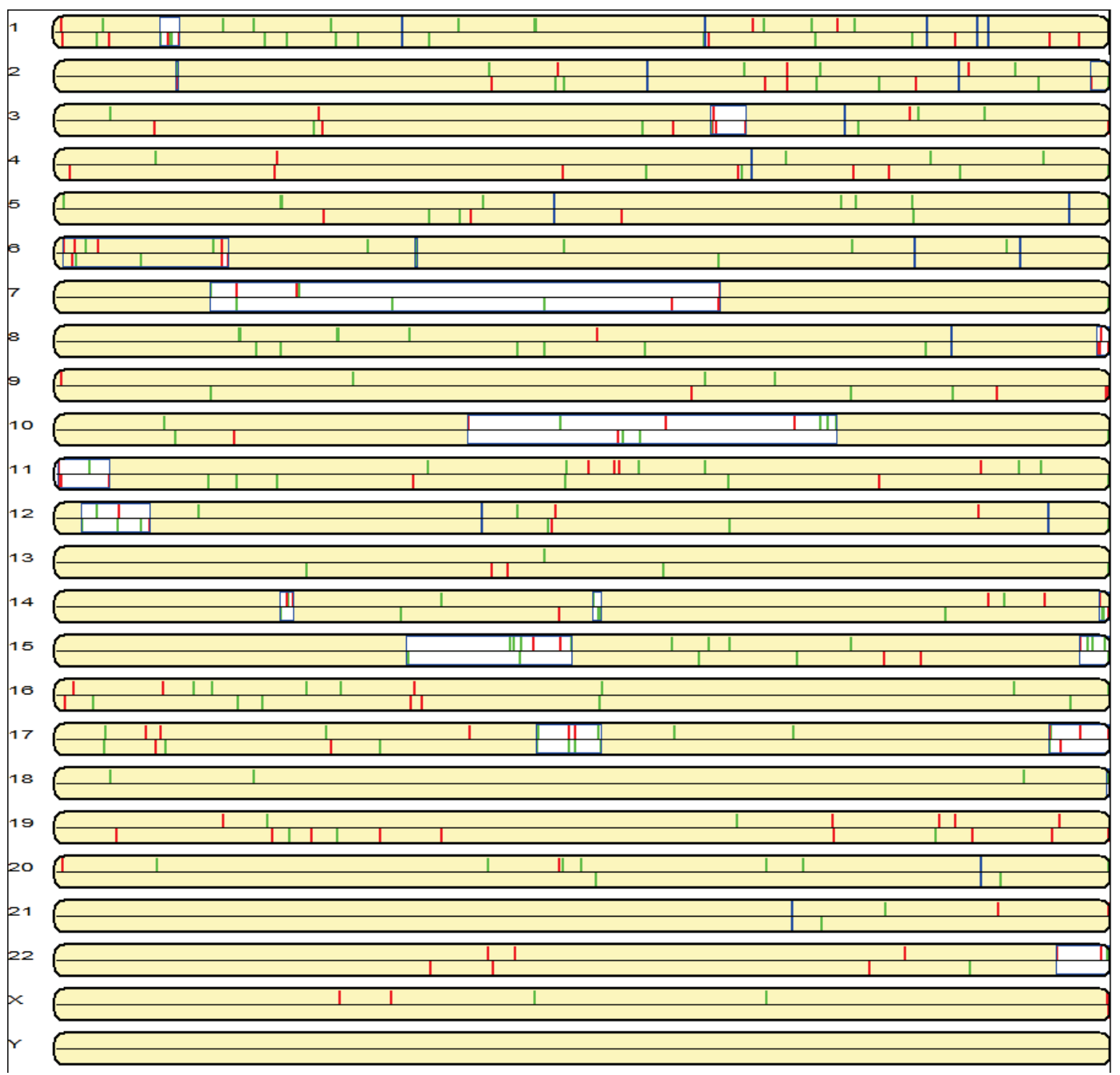

Figure 3.11. Genomic distribution of differentially expressed genes (chromosomes are not drawn to scale) based on comparison of pRTS-1-FLAG-CALM/AF10 expressing cells (pRTS1-FLAG-CALM/AF10 24hrs and pRTS-1-FLAG-CALM/AF10 72hrs) versus controls (pRTS-1 Ohrs, pRTS-1-FLAG-CALM/AF10 Ohrs, pRTS-1 24 hrs, pRTS-1 72 hrs, comparison criterion 5 in table 3.5.).Yellow shading indicates the chromosome and nonshaded areas within the chromosome indicate clusters of differentially regulated that are composed of smaller significant clusters. 


\subsubsection{MicroArray Chromosome Analysis Tool (MACAT)}

The MicroArray Chromosome Analysis Tool (MACAT) aims at linking the term differential gene expression to the chromosomal localization of genes. It is a statistical approach for identifying regions on the chromosomes that contain significantly differentially expressed regions on the chromosomes based on a regularized t-statistic (Toedling et al., 2004).

Class CALM_AF10, Scores for Chromosome 10

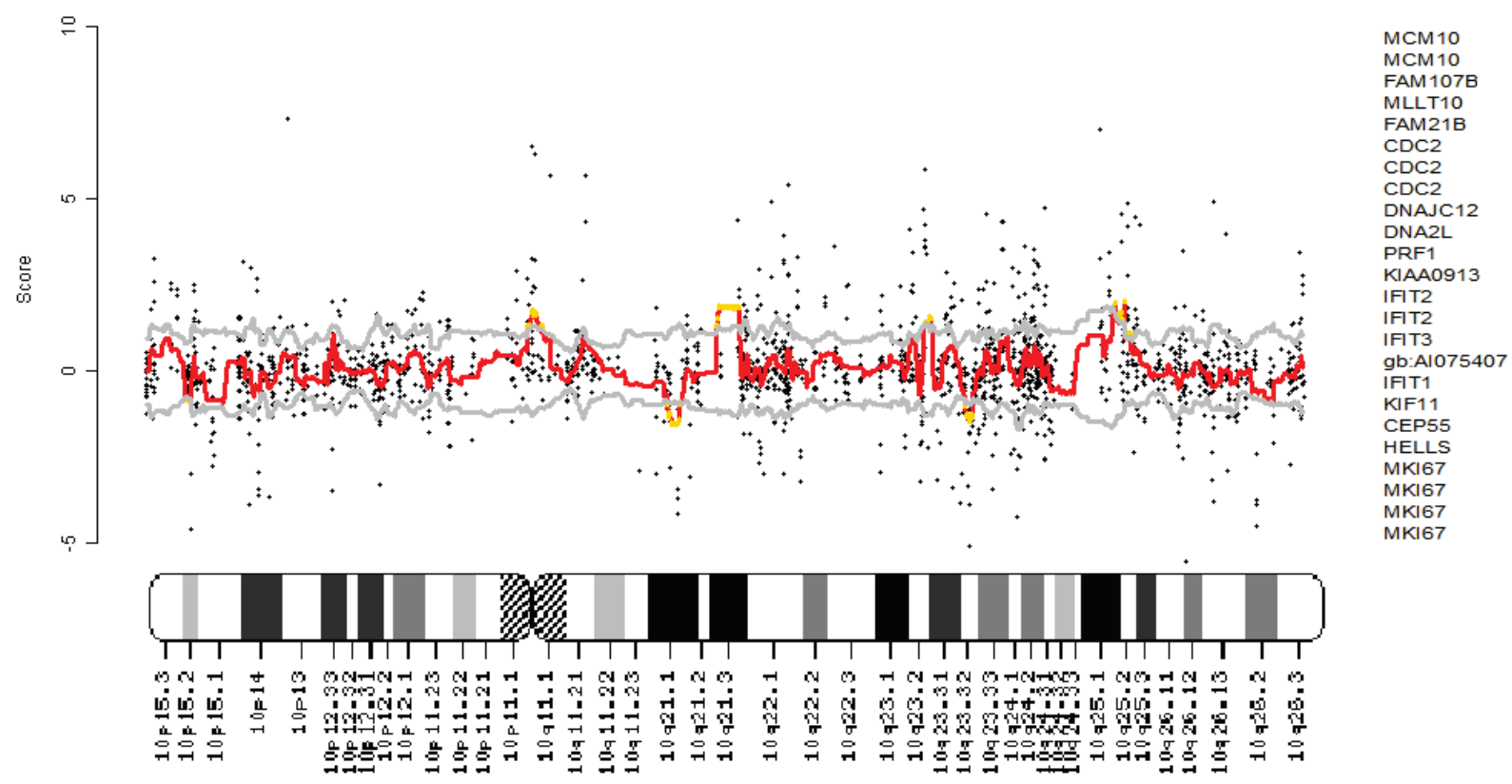

Figure 3.12. MACAT analysis for chromosome 10. Y axis show level of differential regulation for the comparison pRTS-1-FLAG-CALM/AF10 expressing cells (pRTS-1-FLAG-CALM/AF10 24hrs and $p R T S-1$-FLAG-CALM/AF10 72hrs) versus controls (pRTS-1 Ohrs, pRTS-1-FLAG-CALM/AF10 Ohrs, pRTS-1 24 hrs, pRTS-1 72 hrs, comparison criterion 5 in table 3.5). Black points show probesets, the red line indicates the mean fold up or down regulation of probesets of a given gene and grey lines indicate cut offs for differential regulation (1.5 fold in this case). Yellow spots on the red line indicate a gene that satisfies the cut point for differential regulation. The list of probesets that significantly deregulated is given on the right-side of the plot. 


\section{Results}

The MACAT analysis was performed using the Bioconductor(C) implementation of the MACAT package in $\mathrm{R}$ ( $\mathrm{R}$ version 2.8 .1 (2008-12-22), Copyright $(\mathrm{C}) 2008$, The $\mathrm{R}$ Foundation for Statistical Computing) (Toedling et al., 2004). The analysis revealed that there are some closely spaced genes on chromosome 10 that are differentially regulated. The yellow spots indicate genes that are statistically differentially regulated with respect to the calculated t-statistic. The distribution of the genes along chromosome 10 and their probesets are given in figure 3.12. It should be noted that there were no clusters of genes located close enough to each other to suggest co-regulation that could be explained by our current knowledge of chromatin architecture (i.e. genes within a smaller than $1 \mathrm{Mbp}$ region). The MACAT analysis was performed for the entire genome (for all chromosomes) and there were no clusters of genes with very close proximity $(<=100$ $\mathrm{kbp})$ that were significantly differentially regulated.

\subsubsection{Ontology Analysis (GOSurfer)}

One of the major challenges in microarray based experiments is to analyze the data in a way that gives biological insight into the overwhelming amount of data generated. Even though looking at the top up and down-regulated genes in a list of differentially regulated genes seems to be a plausible approach, it is known that biologically relevant gene expression changes might not always be so dramatic. Slight changes in the expression levels in a number of genes belonging to a certain biological processes might be biologically more relevant than a large change in a single gene. As a result, pathway and biological process analysis of microarray data has become one of the important analyses of gene expression profiling studies. Various scientific databases (predominantly Kyoto Encyclopedia of Genes and Genomes (KEGG) and GenMAPP) are striving to arrive at a 
consistent and proper annotation of genes with respect to the processes that they are involved in, the functions that they perform, and where exactly they are found within the cell.

The Gene Ontology (GO) project is a collaborative effort to address the need for consistent description of the function of a gene product in different databases (http://www.geneontology.org/GO.doc.shtml). The project began as collaboration between three model organism databases, FlyBase (Drosophila), the Saccharomyces Genome Database (SGD) and the Mouse Genome Database (MGD), in 1998. The three organizing principles of GO are: cellular component, biological process and molecular function. A gene product might be associated with or located in one or more cellular components; it is active in one or more biological processes, during which it performs one or more molecular functions.

There are many software packages currently available that can build GO hierarchies. The GoSurfer package (Zhong et al., 2004) was used to analyze the microarray data in this study. GoSurfer uses Gene Ontology (GO) information to analyze gene sets obtained from genome-wide computations or microarray analyses (Zhong et al., 2004). It associates user defined gene lists with GO terms and visualizes such GO terms as a hierarchical tree. The tree output can be manipulated by various means, like setting heuristic thresholds or using statistical tests. Significantly important GO terms, which were found to be significant, can be highlighted. 


\section{Results}

\subsubsection{Molecular Function}

The molecular function category describes activities such as catalysis or binding activities that occur at the molecular level. The GO analysis was based on the comparison of pRTS-FLAG-CALM/AF10 samples (pRTS-1-FLAG-CALM/AF10 24hrs and pRTS-1FLAG-CALM/AF10 $72 \mathrm{hrs)} \mathrm{to} \mathrm{the} \mathrm{controls} \mathrm{pRTS-1} \mathrm{0hrs,} \mathrm{pRTS-1-FLAG-CALM/AF10}$ 0hrs, pRTS-1 24 hrs and pRTS-1 72 hrs (comparison criterion 5 in table 3.5, 477 genes). The GO analysis of the microarray data revealed that binding, transcription regulator activity (subcategory transcriptional repressor activity) and catalytic activity were the three GO molecular function classes in which the differentially regulated genes were statistically overrepresented. Subcategories within the binding class that contained most of the differentially regulated genes were "damaged DNA binding", "chromatin binding", and "tubulin binding" (Figure 3.13). 


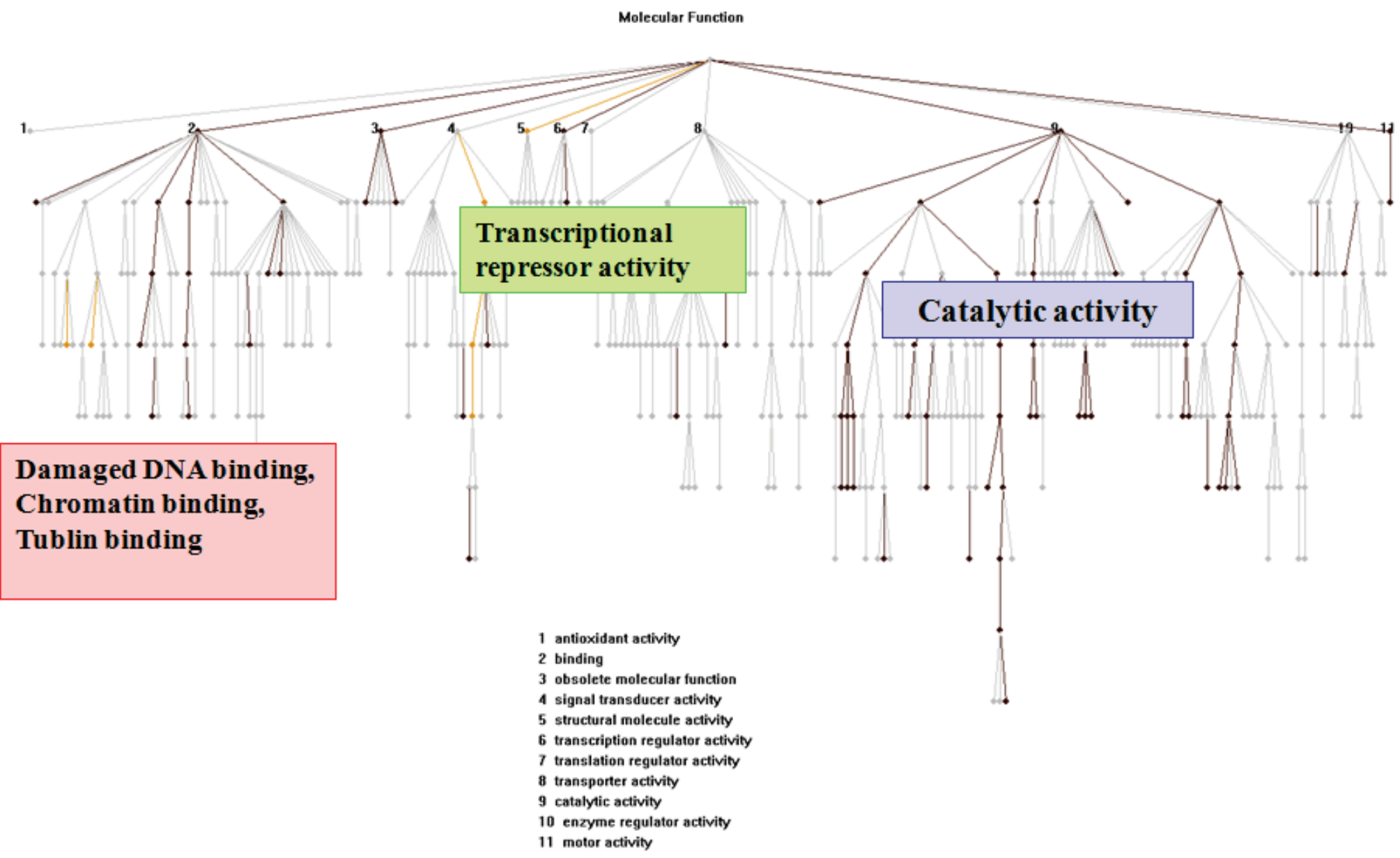

Figure 3.13. Molecular Function. The GO molecular function is classified into 11 functional classes (list shown at the bottom of the figure). Functional classes that showed strong enrichment of the differentially regulated genes based on the comparison of pRTS-FLAG-CALM/AF10 samples (pRTS-1-FLAG-CALM/AF10 24hrs and pRTS-1-FLAG-CALM/AF10 72 hrs) to the controls (pRTS-1 Ohrs, pRTS-1-FLAG-CALM/AF10 Ohrs, pRTS-1 24 hrs and pRTS-1 72 hrs, comparison criterion 5 in table 3.5, 477 genes) are highlighted. Dark brown and orange branches were found to be statistically significant for the enrichment of the genes in those sub-categories of molecular functions (boxes with different colors and labels), whereas grey branches are statistically not significant. 
Biological Process

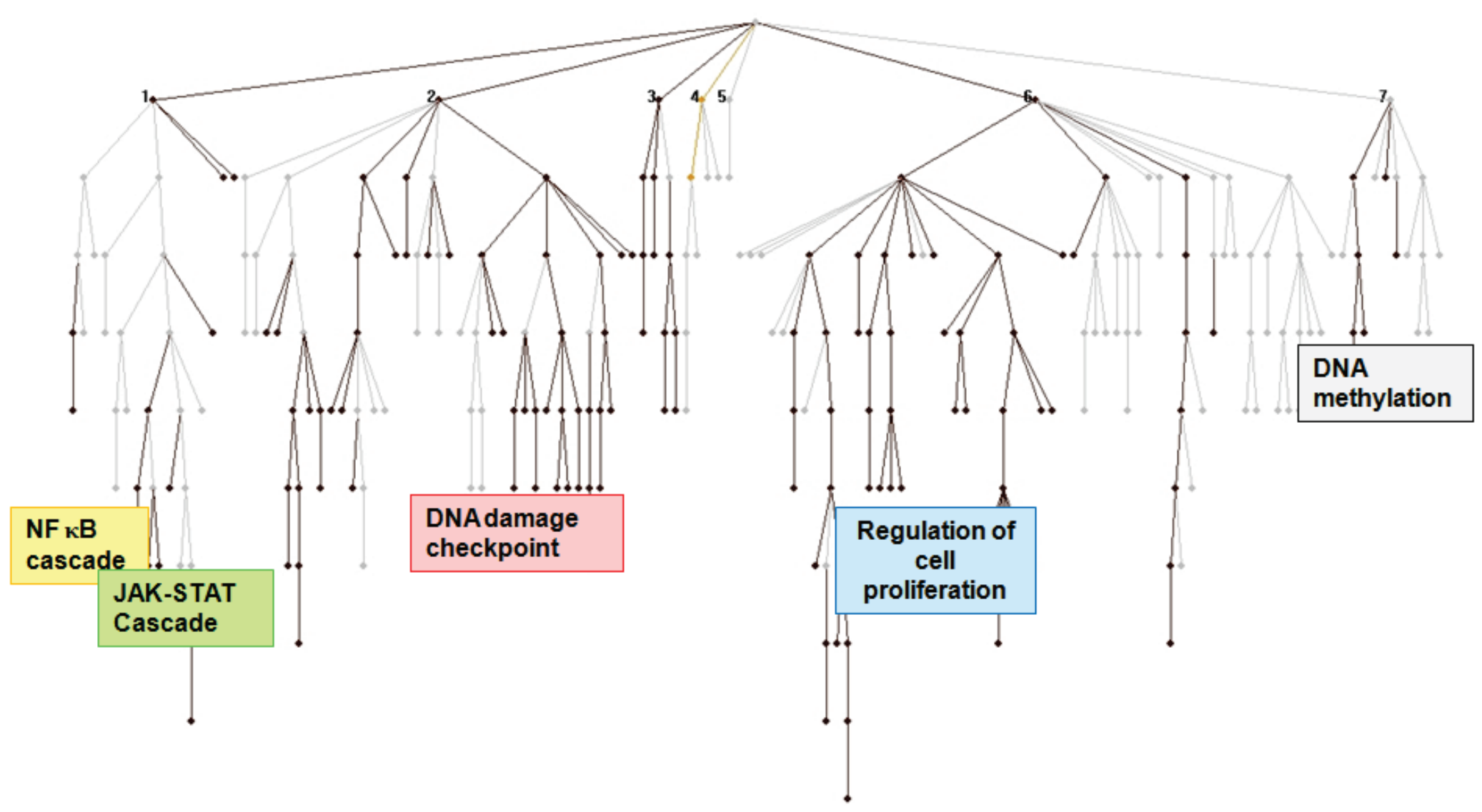

Figure 3.14. Biological Process. The GO molecular function is classified into 7 biological processes. Biological processes that showed strong enrichment of the differentially regulated genes based on the comparison of pRTS-FLAG-CALM/AF10 samples (pRTS-1-FLAG-CALM/AF10 24hrs and pRTS-1-FLAG-CALM/AF10 72 hrs) to the controls (pRTS-1 Ohrs, pRTS-1-FLAG-CALM/AF10 0hrs, pRTS-1 24 hrs and pRTS-1 72 hrs, comparison criterion 5 in table 3.5, 477 genes) are highlighted. Dark brown and orange branches were found to be statistically significant for the enrichment of the genes in those sub-categories of biological processes (boxes with different colors and labels) whereas grey branches are statistically not significant. 


\subsubsection{Biological Process}

A biological process is series of events accomplished by one or more ordered assemblies of molecular functions. Examples of broad biological process terms are cellular physiological process or signal transduction. Examples of more specific terms are pyrimidine metabolic process or alpha-glucoside transport. It can be difficult to distinguish between a biological process and a molecular function, but the general rule is that a process must have more than one distinct steps. A biological process is not equivalent to a pathway.

Genes from several important biological processes were were significantly overrepresented in the set of differentially regulated genes comparing pRTS-FLAGCALM/AF10 samples (pRTS-1-FLAG-CALM/AF10 24hrs and pRTS-1-FLAGCALM/AF10 $72 \mathrm{hrs}$ ) to the controls pRTS-1 0hrs, pRTS-1-FLAG-CALM/AF10 0hrs, pRTS-1 24 hrs and pRTS-1 72 hrs (comparison criterion 5 in table 3.5, 477 genes). The biological processes that showed statistically significant enrichment among the differentially regulated genes were: NFKB cascade, JAK-STAT cascade, DNA damage checkpoint, and regulation of cell proliferation (Figure 3.14). To further understand which genes in these pathways are affected and how this would affect the whole process, a pathway analysis was carried out.

\subsubsection{Pathway Analysis (KegArray)}

The Kyoto Encyclopedia of Genes and Genomes (KEGG) is a database for uncovering higher-order systemic behaviors of the cell and the organism from genomic and molecular information (Kanehisa and Goto, 2000). The KEGG consortium developed a 


\section{Results}

number of algorithms that assist the analysis of data sets (e.g. microarray, Real-time PCR or sequencing) by exploiting the information available in the KEGG database. KegArray, for instance, is a tool developed to schematically display the distribution of differentially regulated genes in a given pathway.

Since our data set revealed, based on the hierarchical clustering and GO biological process findings, that cell cycle and DNA damage and repair are some of the significantly affected pathways/processes, the KegArray tool was used to investigate this in further detail.

\subsubsection{Cell cycle}

Except for three genes (SMAD2/3, Ink $4 a-d$, and $A T M / A T R)$, all the differentially regulated genes involved in cell cycle regulation were downregulated (Figure 3.15), based on comparison of pRTS-1-FLAG-CALM/AF10 samples (pRTS-1-FLAGCALM/AF10 24hrs and pRTS-1-FLAG-CALM/AF10 $72 \mathrm{hrs)} \mathrm{to} \mathrm{the} \mathrm{controls} \mathrm{(pRTS-1}$ 0hrs, pRTS-1-FLAG-CALM/AF10 0hrs, pRTS-1 24 hrs and pRTS-1 72 hrs; comparison criterion 5 in table 3.5). Two of the six origin recognition complex (ORC) genes and four of the six mini-chromosome maintenance (MCM) genes were down-regulated. How the down-regulated and up-regulated genes interact and how CALM/AF10 might affect the cell cycle will be described in more detail in the discussion section.

\subsubsection{DNA damage checkpoint and DNA repair}

The list of differentially regulated genes includes a number of genes that have been implicated in various types of cancer including $B R C A 1, D D B 2, C H E K 1$ and RAD5. All four genes were down-regulated (comparison criterion 5 in table 3.5). Most of the other 
genes in this category were also down regulated, indicating that DNA damage checkpoint is one of the important pathways affected early after the expression of CALM/AF10. Figure 3.16 shows the nucleotide excision repair process and some of the genes ( $D D B 2$, $P C N A$, and $L I G 1)$ that were found to be differentially regulated in our comparison stated above. 


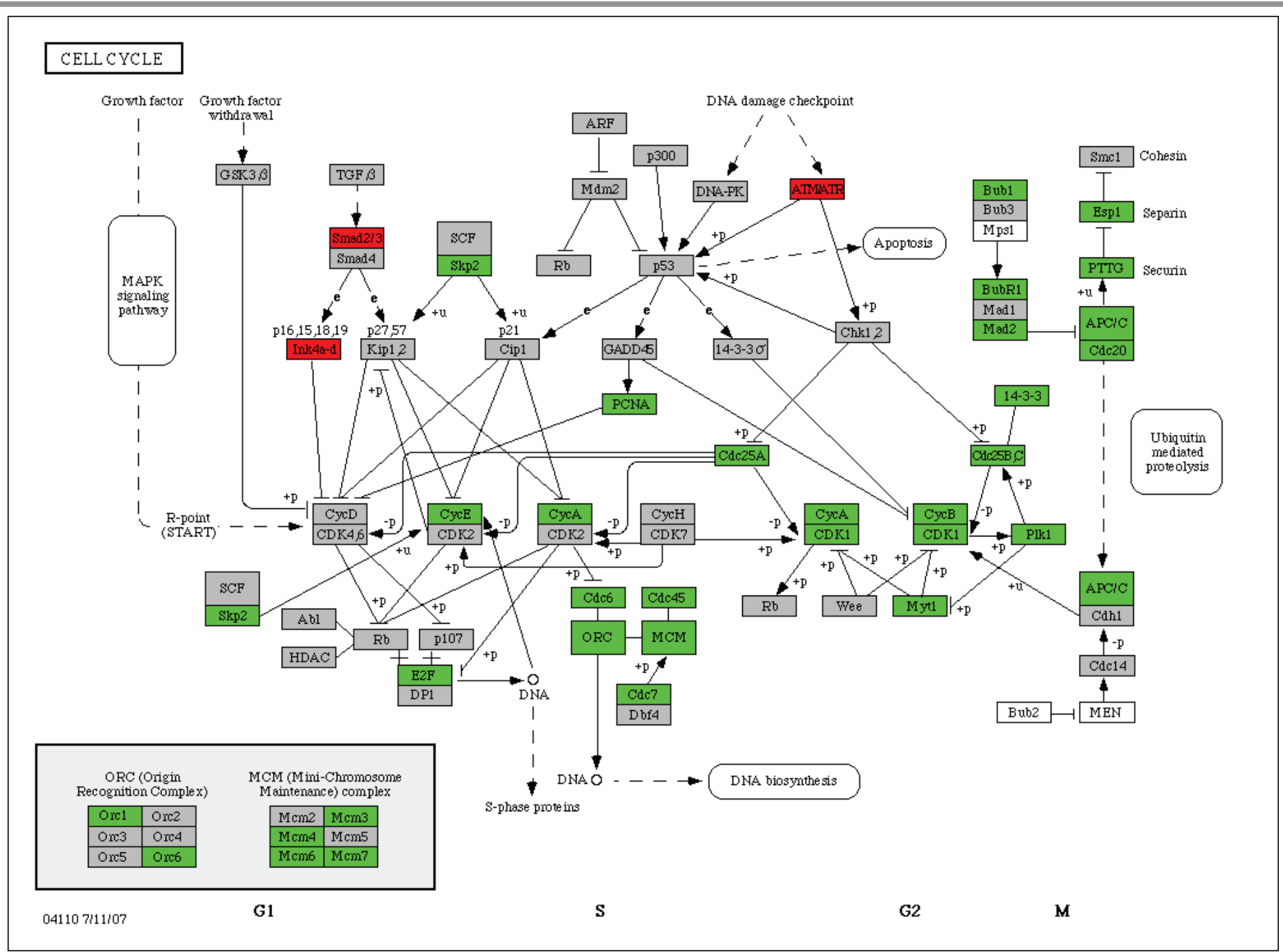

Figure 3.15. Cell cycle based on KEGG. Green boxes are down-regulated genes and red are up-regulated. Grey indicate genes that are not differentially regulated (based on comparison of pRTS-1-FLAG-CALM/AF10 samples (pRTS-1-FLAG-CALM/AF10 24hrs and pRTS-1-FLAGCALM/AF10 $72 \mathrm{hrs}$ ) to the controls (pRTS-1 Ohrs, pRTS-1-FLAG-CALM/AF10 0hrs, pRTS-1 24 hrs and pRTS-1 72 hrs (comparison criterion 5 in table 3.5)). 
NUCLEOTIDE EXCISION REPAIR

Eukaryotic type
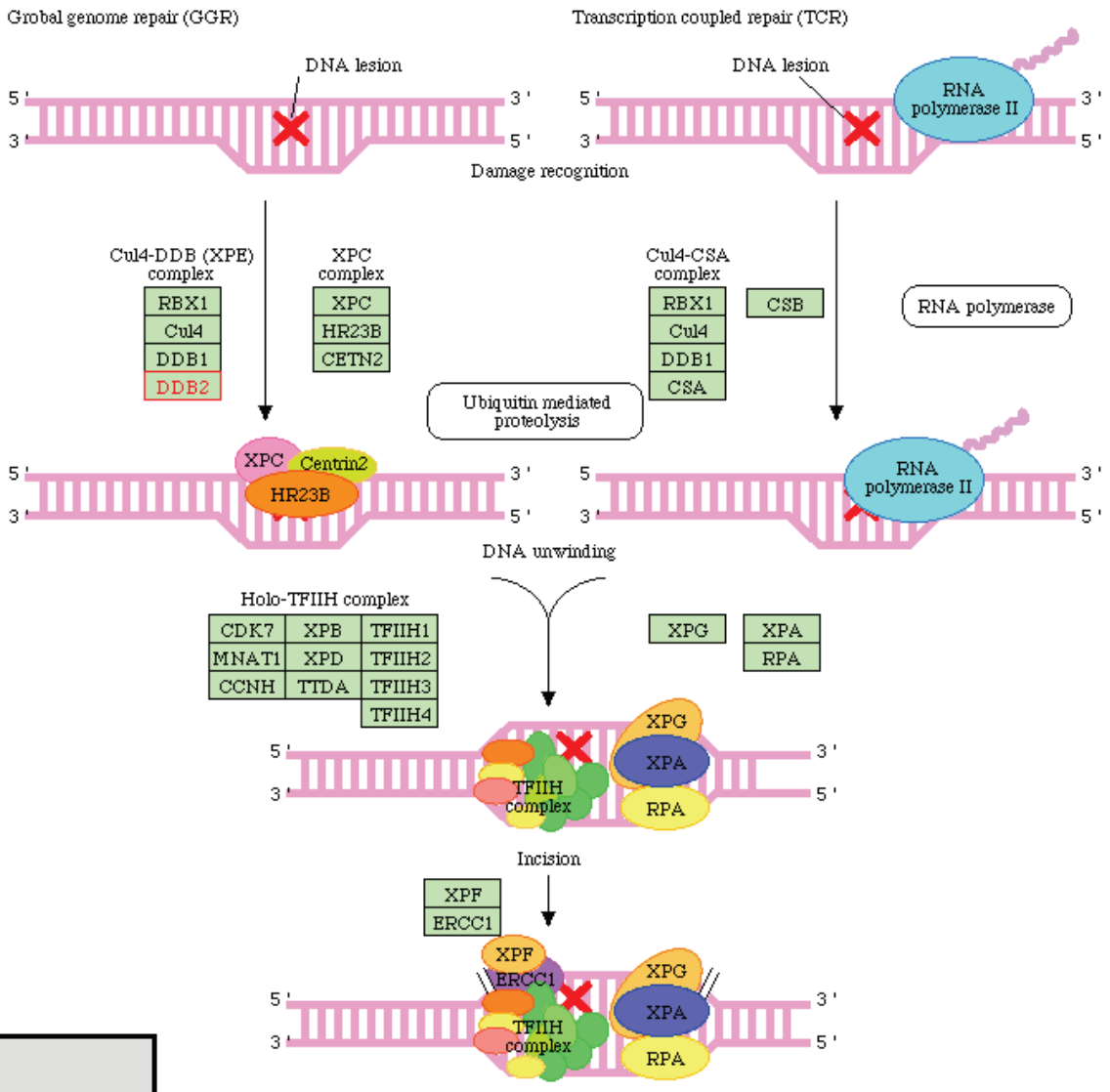

Holo-TFIIH complex

Ubiquitin ligase

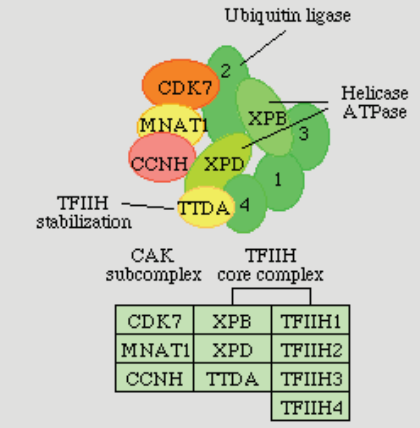

Excision and DNA synthesis

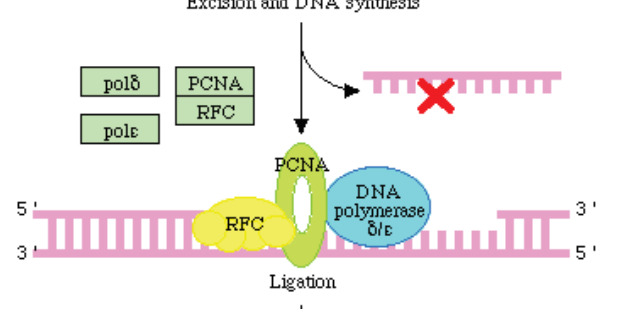

Lig1

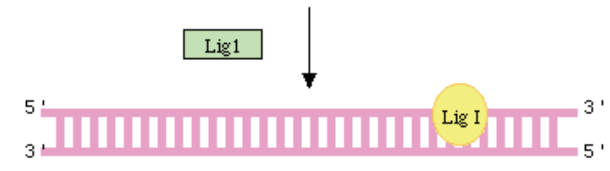

$03420 \quad 213109$

(c) Kanehisa Laboratories

3.16. Nucleotide excision repair based on KEGG. A number of genes involved in Nucleotide excision repair (part of the DNA damage repair) including LIG1, DDB2 and PCNA were downOregulated in the comparison of the pRTS-1-FLAG-CALM/AF10 samples (pRTS-1-FLAGCALM/AF10 24hrs and pRTS-1-FLAG-CALM/AF10 $72 \mathrm{hrs)} \mathrm{with} \mathrm{the} \mathrm{controls} \mathrm{(pRTS-1} \mathrm{Ohrs,}$ pRTS-1-FLAG-CALM/AF10 Ohrs, pRTS-1 24 hrs and pRTS-1 72 hrs) (comparison criterion 5 in table 3.5). 


\subsubsection{Comparison with patient data (Gene Set Enrichment Analysis, GSEA)}

The Gene Set Enrichment Analysis is another powerful pathway/biological process orientated analytical method that derives its power by focusing on gene sets, which are defined as groups of genes that share common biological function, chromosomal location, or regulation (Subramanian et al., 2005). Notably, where single-gene analysis finds little similarity between two independent studies (like patient data and cell line data), GSEA might reveal many biological pathways which are affected in both studies. A false discovery rate (FDR) adjustment can be made for multiple testing by setting a certain threshold.

In the current study, it was attempted to employ the power of this tool to find pathways that might be affected by CALM/AF10 both in the patient data set and the cell line data set of this study.

The patient data set used here is derived from microarray based (Affymetrix platform) expression profiling study using mononuclear cells from bone marrow aspirates collected from patients with CALM/AF10 and other types of leukemia. $10 \mathrm{CALM} / \mathrm{AF} 10^{+} \mathrm{AML}$ and ALL patients were compared to 119 patients with various types of leukemia (CML, ALL with $1 ; 19$ or $4 ; 11$, ALL with MLL rearrangement, ALL, ALL with Ph+, AML with MLL rearrangement, AML normal karyotype, AML normal karyotype FLT3+, AML with inv(16), AML with $\mathrm{t}(8 ; 21)$, AML with $\mathrm{t}(15 ; 17)$, AML with complex karyotype; all with 10 samples each except the group of ALL with MLL rearrangements (9)). 10 normal bone marrow samples were also included in the study. The purpose of the study was to identify genes which are up and down-regulated in CALM/AF10 patients as compared to other classes of leukemia and normal bone marrow controls. As the nature of the samples 
and the comparison method in the patient data set and the cell line data set are not suited for direct comparison, the aim of GSEA is to assess if there are some pathways affected by CALM/AF10 both in the cell line data (immediate target genes) and in the patient data (differentially regulated genes compared to other leukemia subtypes).

The list of genes that were found to be differentially regulated in the cell line data (comparison of pRTS-1-FLAG-CALM/AF10 samples (pRTS-1-FLAG-CALM/AF10 24hrs and pRTS-1-FLAG-CALM/AF10 $72 \mathrm{hrs)} \mathrm{to} \mathrm{the} \mathrm{controls} \mathrm{(pRTS-1} \mathrm{0hrs,} \mathrm{pRTS-1-}$ FLAG-CALM/AF10 0hrs, pRTS-1 24 hrs and pRTS-1 $72 \mathrm{hrs)} \mathrm{were} \mathrm{used} \mathrm{as} \mathrm{a} \mathrm{reference}$ gene set for the GSEA. The reference gene set is the set of genes that was used to build the enrichment analysis when comparing the CALM/AF10 patient data to all the other classes of leukemia (a t-test was used as a metric for finding and ranking differentially regulated genes when comparing CALM/AF10 patient microarray data to other patient classes). In the process, for every match in the reference gene list with the comparison of patient samples for differentially regulated genes in CALM/AF10 patients is encountered, a positive score is entered, named as Enrichment Score (ES). The ES increase steeply if more genes in the reference list are matching with the most differentially regulated genes in the patient microarray data comparisons. The GSEA was run with 1000 iterations based on the reference gene set from the cell line data, there were no statistically enriched genes in the patient comparison. This implies that the set of genes that were differentially regulated in the cell line data are different from the set of differentially regulated genes in the patient data.

To assess if biological processes or molecular functions that were enriched in the cell line data from the GO and KEGG analysis would also be implicated in the patient data, the 


\section{Results}

GSEA was carried out on the patient data using GO biological process and molecular function as a reference gene set. Using this approach, we discovered that the pathway "DNA repair" was significantly enriched both in the cell line data and the patient data, even though the list of differentially regulated genes in the two different settings (cell line data and patient data) did not overlap. Figure 3.17 summarizes the result of the GSEA of the patient and cell line data. The involvement of DNA repair in both data sets indicates that a compromised DNA repair pathway with its ensuing genomic instability might be one of the oncogenic mechanisms of CALM/AF10-mediated leukemogenesis. 
(a)

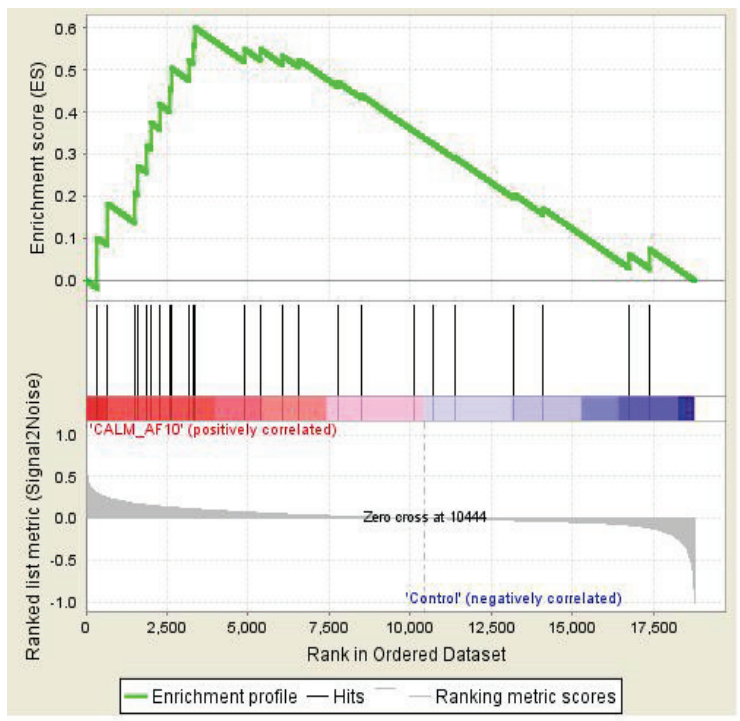

(b)

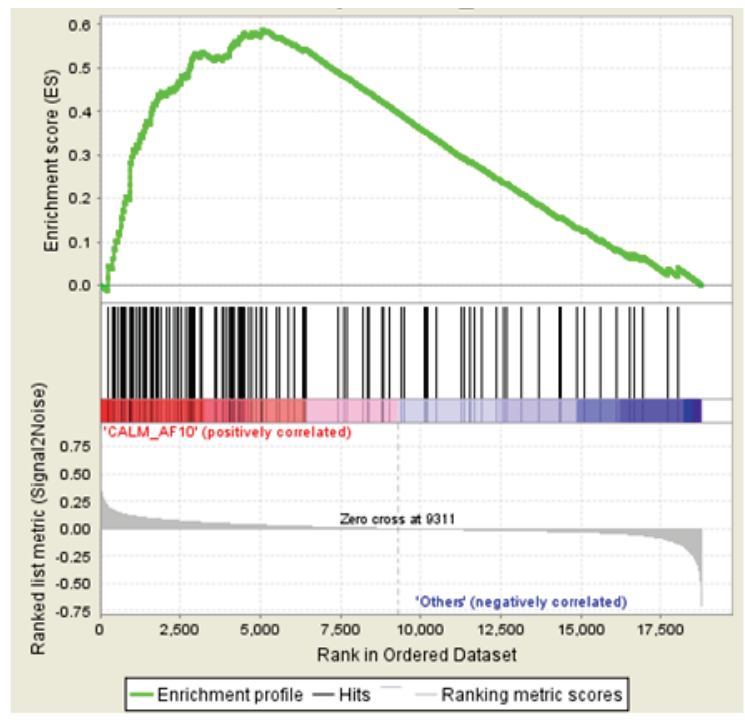

Figure 3.17. GSEA based on cell line and patient data described above (section 3.4.7.).(a) Enrichment of genes involved in DNA repair in the list of differentially regulated genes obtained by comapring pRTS-1-FLAG-CALM/AF10 24hrs and pRTS-1-FLAG-CALM/AF10 72 hrs to the controls (pRTS-1 Ohrs, pRTS-1-FLAG-CALM/AF10 Ohrs, pRTS-1 24 hrs and pRTS-1 72 hrs) (b) 10 CALM/AF10+ AML and ALL patients were compared to CML, ALL with 1;19 or 4;11, ALL with MLL rearrangement, ALL, ALL with Ph+, AML with MLL rearrangement, AML normal karyotype, AML normal karyotype FLT3+, AML with inv(16), AML with t(8;21), AML with t(15;17), AML with complex karyotype, and Normal bone marrow samples; all with 10 samples each except ALL with MLL rearrangement (9)). After evaluation of differentially regulated genes based on a t-statistic, the genes were arranged in ascending order. Based on this ordered list, the GSEA gives a positive score (y axis) for every gene encountered that belongs to the DNA repair process (green curve). Each hit is represented by a vertical bar on the $x$ axis. The stronger the enrichment of genes belonging to DNA repair, the higher will be the density of bars on the left most side of the $x$ axis.

\subsection{Verification of Potential Target Genes by Real Time PCR (Taqman ${ }^{\circledR}$}

\section{Low Density Array)}

The differential expression of genes found in microarray study is often validated using real-time reverse transcription PCR (RT-PCR) assays.

Real-time reverse-transcriptase (RT) PCR is able to quantify the amount of the template very specifically, sensitively and reproducibly. Real-time PCR monitors the fluorescence 
emitted during the reaction as an indicator of amplicon production during each PCR cycle (i.e. in real time) as opposed to endpoint detection (Dorak, 2006). In comparison to conventional RT-PCR, real-time PCR also offers a much wider dynamic range of up to $10^{7}$-fold (compared to 1000 -fold in conventional RT-PCR). The dynamic range of any assay determines how much the target concentration can vary and still be quantified. A wide dynamic range ensures that a wide range of ratios of target and normalizer can be assayed with equal sensitivity and specificity (Dorak, 2006). It follows that the broader the dynamic range is, the more accurate the quantitation is. In real-time RT-PCR assays, expression is normalized to a control or housekeeping gene.

An important parameter in real-time PCR analysis is the $\mathrm{C}_{\mathrm{t}}$ value, a threshold cycle that should be placed above any baseline activity and within the exponential phase (which looks linear in the log transformation) (Dorak, 2006) of PCR amplification. The Ct is thus the cycle at which the PCR reaction has reach mid-phase of the exponential increase phase, and it serves as a reference cycle for subsequent analysis and comparison between different samples in a given experiment.

TaqMan ${ }^{\circledR}$ Low-Density Arrays based real-time PCR is a medium-throughput method using microfluidics to simultaneously assay the expression of many genes (Lynne V. Abruzzo et al., 2005). For the details of experimental setup, please see Materials and methods section on the Taqman Low Density Array.

We selected ninety four genes from the list of significantly differentially regulated genes (comparing pRTS-1-FLAG-CALM/AF10 samples (pRTS-1-FLAG-CALM/AF10 24hrs and pRTS-1-FLAG-CALM/AF10 $72 \mathrm{hrs)} \mathrm{to} \mathrm{the} \mathrm{controls} \mathrm{(pRTS-1} \mathrm{0hrs,} \mathrm{pRTS-1-FLAG-}$ 
CALM/AF10 0hrs, pRTS-1 24 hrs and pRTS-1 $72 \mathrm{hrs}$ )) for validation of their expression changes by real-time RT-PCR on the LDA (the genes are listed in Appendix A7). Two house-keeping genes $(\beta$-actin and GAPDH) were included in the validation real-time PCR experiment. The differentially regulated genes were selected based on the overall assessment of the analysis of the microarray data and their potential and known biological significance in leukemogenesis and hematopoietic development.

The cDNA that was used for the LDA real-time PCR was produced from the same total RNA that was used as a starting material for the microarray study. All samples from all time points (non-induced, $24 \mathrm{hrs}$ after induction, and $72 \mathrm{hrs}$ after induction) were included in the real-time PCR study. The cDNA synthesis was performed 3 times from the RNA that was used as a starting material for the microarray study and each synthesis product was used as a replicate for the LDA experiment. Samples were loaded randomly on an LDA (no systematic order) to avoid bias. The Materials and Methods section on the Taqman Low Density Array describes the LDA protocol and machine setup.

Once the data were acquired successfully, the individual $C_{t}$ values of the assayed genes (Figure 3.18) were normalized against the geometric mean of the $C_{t}$ value of the two internal control genes ( $\beta$-actin and GAPDH). The raw amplification kinetics of the 94 genes on the TaqMan system is shown in figure 3.18. As can be seen in this figure most of the genes had a $\mathrm{C}_{\mathrm{t}}$ value in the range of 25 to 37 (80.1\% of the genes). Very few genes (3.7\%) showed a relatively narrow $\mathrm{C}_{t}$ value range (high expression level), ranging from 20 to 22. After completion of the normalization, the data points were exported to a spreadsheet for further statistical analysis. 


\section{Results}

The fold expression change for the 94 genes was calculated using the same approach used for the microarray data (Table 3.5), the only difference being in the LDA data that the mean expression value (and standard deviation) for each gene in a given sample was calculated based on the 3 replicates per sample that were included in the LDA experiment.

The list of genes and their fold expression for the comparison pRTS-1-FLAGCALM/AF10 samples (pRTS-1-FLAG-CALM/AF10 24hrs and pRTS-1-FLAGCALM/AF10 $72 \mathrm{hrs}$ ) to the controls pRTS-1 0hrs, pRTS-1-FLAG-CALM/AF10 0hrs, pRTS-1 24 hrs and pRTS-1 72 hrs) in both the real-time PCR analysis and in the microarray experiments is given in Appendix A7. 


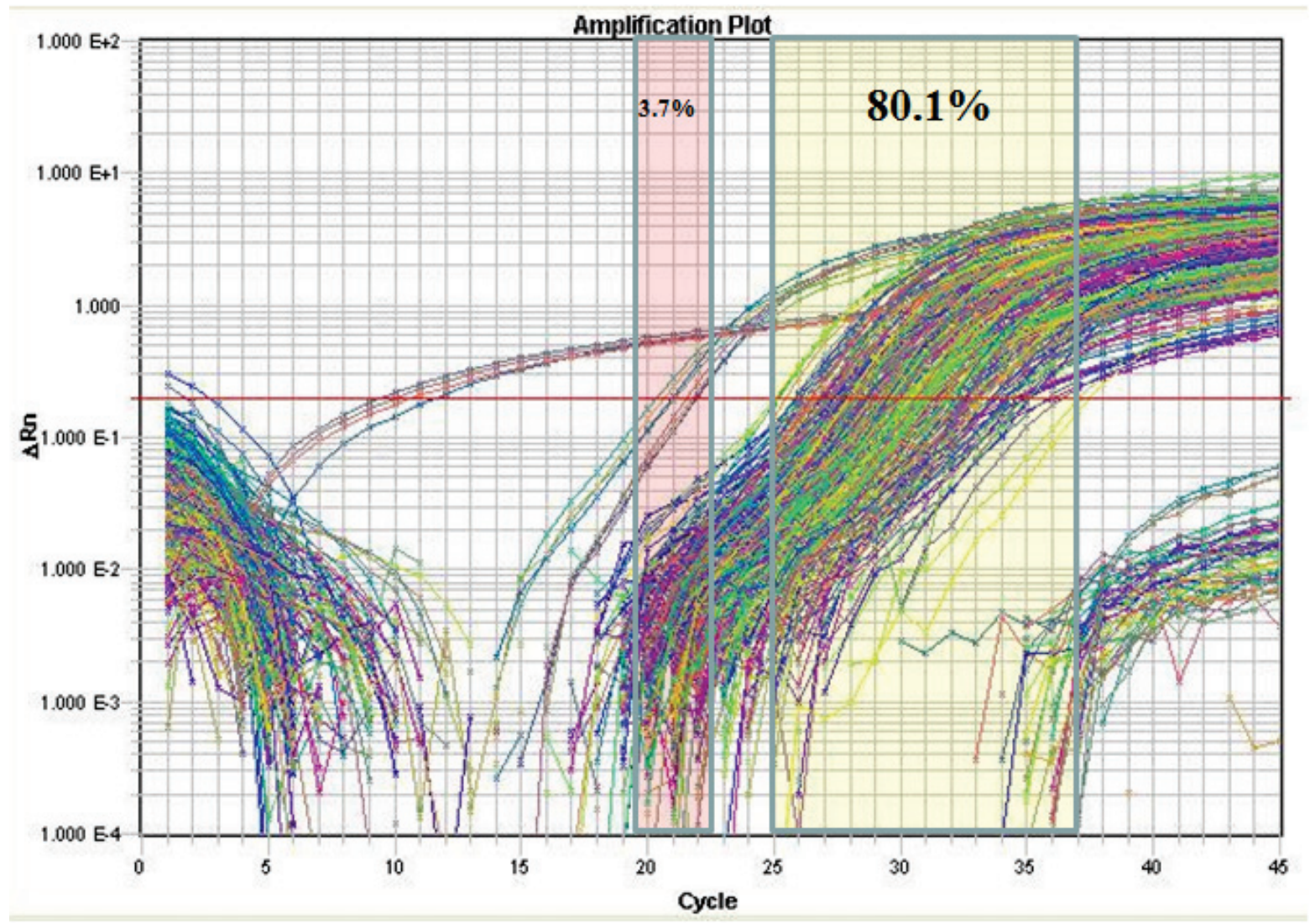

Figure 3.18. Raw real-time PCR data of the 94 genes and all samples in the experiment. Y axis is the magnitude of the signal generated by the given set of PCR condition and is calculated by taking the difference between $\mathrm{Rn}+$ (the reaction containing all components, including the template) and $\mathrm{Rn}$ - (the reaction without the template) ( $\mathrm{Rn}$ is the fluorescence emission intensity of the reporter dye divided by the fluorescence emission intensity of the passive reference dye). Red horizontal line is the $C_{t}$ value, which is calculated automatically by the software). The $X$ axis represents the cycle number. Different colors indicate readings for different genes. $80.1 \%$ of the assayed genes had Ct values ranging from 25 to 37.

\subsubsection{Comparison between array and LDA data}

The fold expression changes obtained from the LDA real-time PCR analysis were compared to the fold expression changes observed in the microarray data, based on the comparison pRTS-1-FLAG-CALM/AF10 samples (pRTS-1-FLAG-CALM/AF10 24hrs and pRTS-1-FLAG-CALM/AF10 $72 \mathrm{hrs)} \mathrm{to} \mathrm{the} \mathrm{controls} \mathrm{(pRTS-1} \mathrm{0hrs,} \mathrm{pRTS-1-FLAG-}$ CALM/AF10 0hrs, pRTS-1 24 hrs and pRTS-1 72 hrs). A Pearson's correlation analysis 


\section{Results}

revealed that there was a strong correlation between the two data sets (table 3.8 and figure 3.19). If one considers the absolute value of the fold expression change as shown in figure $3.19 ., 78 \%$ of the genes in the validation list were consistent in the direction of their regulation (most genes up-regulated in the microarray data set upon CALM/AF10 expression were also found to be up-regulated in the LDA analysis; and the same was true for the down-regulated genes). Some gene that did not show matching direction of deregulation include IFI27, USP18, TLX2, RAB8B.

The difference in the magnitude of differential regulation between the real-time PCR data and the microarray data was also evaluated for the pRTS-1-FLAG-CALM/AF10 24hrs and pRTS-1-FLAG-CALM/AF10 $72 \mathrm{hrs)} \mathrm{to} \mathrm{the} \mathrm{controls} \mathrm{(pRTS-1} \mathrm{0hrs,} \mathrm{pRTS-1-FLAG-}$ CALM/AF10 0hrs, pRTS-1 24 hrs and pRTS-1 72 hrs) comparison. It was observed that there is an overall higher magnitude of differential regulation (on average 2.5 fold higher) in the real time PCR data as compared to the microarray data. This difference in the magnitude of fold expression can be accounted for by the greater dynamic range of realtime PCR as compared to the Affymetrix microarray. 
Table 3.8. Pearson's correlation of Affymetrix data and real-time PCR LDA data (In bold, significant values (except diagonal) at the level of significance alpha $=0.050$ (two-tailed test))

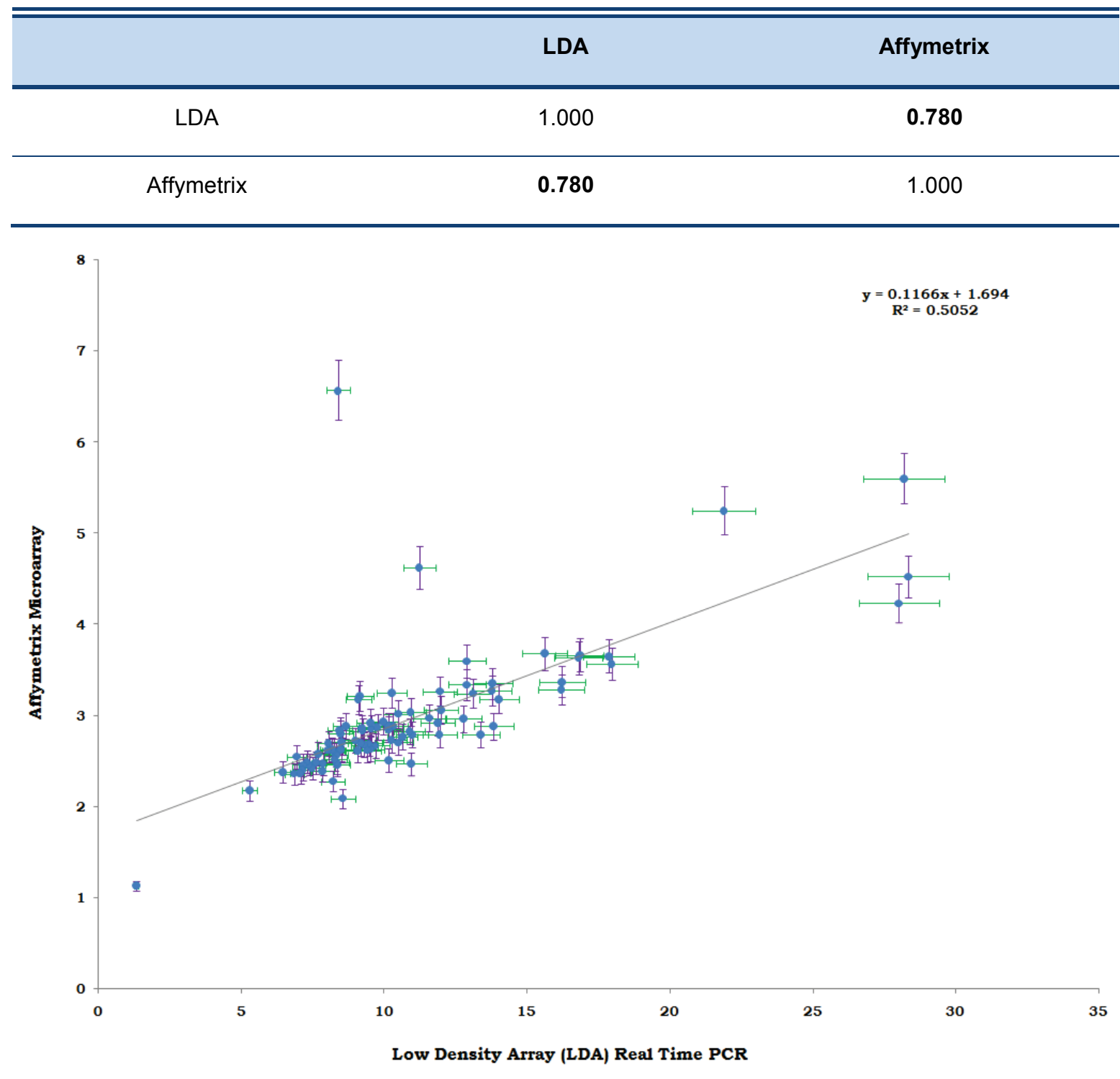

Figure 3.19. Correlation of microarray data and LDA real-time PCR data. The X axis represents the fold difference in regulation of the selected genes in the real-time PCR setting for the comparison of pRTS-1-FLAG-CALM/AF10 24hrs and pRTS-1-FLAG-CALM/AF10 72 hrs to the controls (pRTS-1 Ohrs, pRTS-1-FLAG-CALM/AF10 Ohrs, pRTS-1 24 hrs and pRTS-1 72 hrs) (log2 scale, green error bars indicating standard deviation for the fold regulation based on the technical replicates). $Y$ axis indicates fold regulation for microarray data for the same comparison criterion, purple error bars indicating 95\% confidence intervals. 


\section{Discussion}

It was the aim of this work to identify the early or immediate targets of CALM/AF10. To achieve this CALM/AF10 was expressed from the inducible mammalian expression vector pRTS-1 in the cell line DG-75, and the changes in the expression levels of $\sim 20,000$ genes was measured by expression profiling on the Affymetrix platform. The conditional expression of a gene of interest gives control over the time and dose of expression of the gene to be induced. As clean and appealing as a conditional expression system is there are some inherent limitations which have to be considered. The choice of the cell line plays a critical role in an experiment like ours, as the appropriateness of the cell line for the problem to be addressed and the technical feasibility of using the cell line have to be reconciled. For instance, out of the different cell lines screened for this work, the DG-75 cell line performed best with regard to inducibility and absence of leaky expression of CALM/AF10 prior to induction. DG-75 is a human memory pro B cell line (Burkitt's lymphoma cell line) and is certainly appropriate for this work as it is a hematopoietic. However, this cell line is a partially differentiated cell line and has accumulated certain epigenetic modifications that might mask the effect of CALM/AF10 on certain target genes. Despite the afro mentioned limitations and other intrinsic setbacks, gene expression profiling using Affymetrix ${ }^{\circledR}$ microarray of the different samples collected at different time points after induction of expression of CALM/AF10 provided us with a good overview of the transcriptional consequence of CALM/AF10 both at the gene and pathway level. 
It is quite obvious that the number of differentially regulated genes in this is study is very large and these results cannot be discussed in all the details. Therefore, we chose to focus our discussion on the genes and pathways that appeared most relevant to us and that were validated in our real time PCR experiments (see results section and figure 4.1).

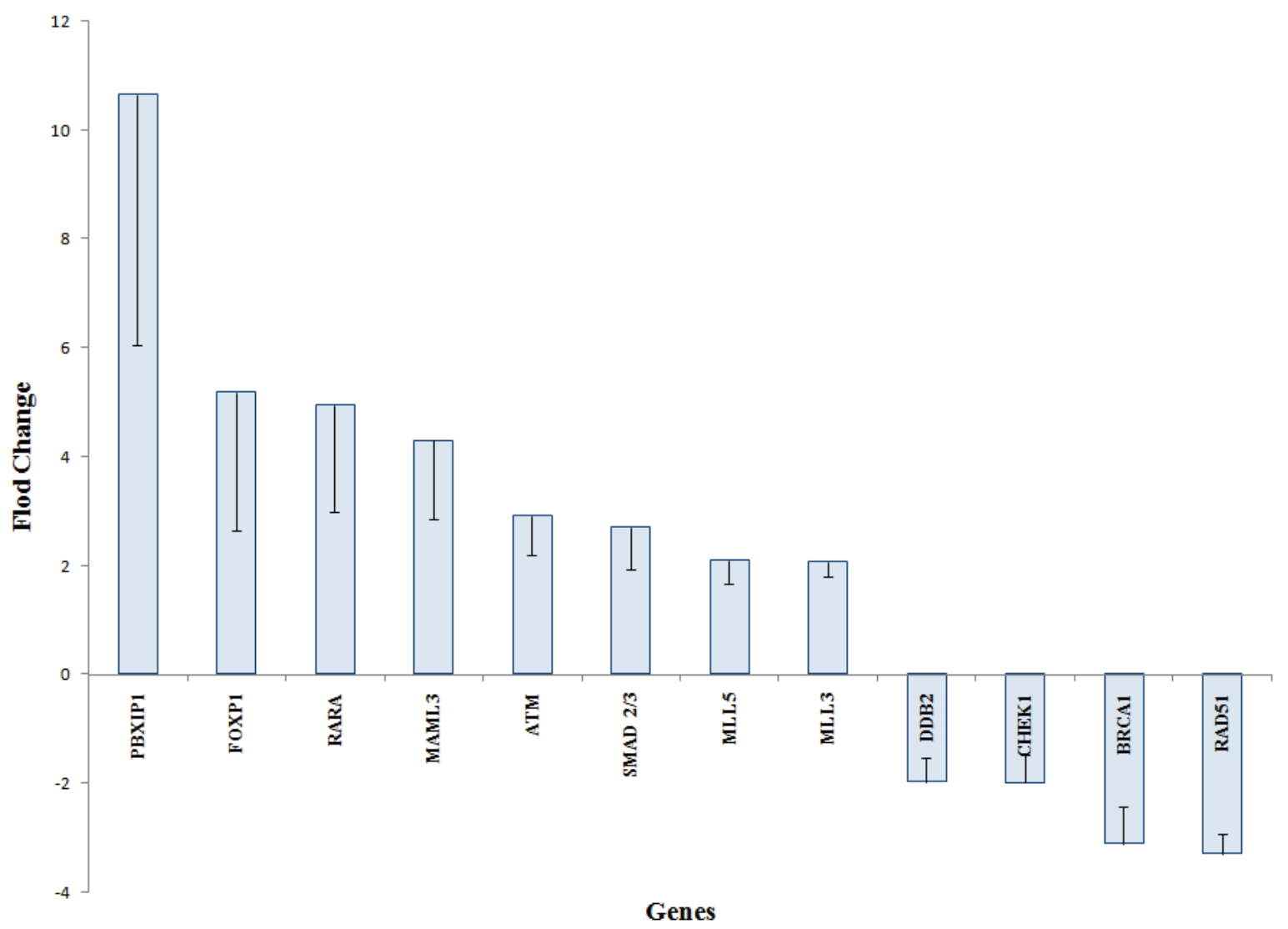

Figure 4.1. Some selected genes differentially regulated after CALM/AF10 expression in the $D G-75$ cell line.

\subsection{Some genes implicated in cancer are immediate targets of}

\section{CALM/AF10}

\section{BRCA1}

Several known oncogenes and tumor suppressor genes were found to be differentially regulated after CALM/AF10 expression. BRCA1 (breast cancer 1, early onset), is one of these genes. BRCA1 was down-regulated in DG-75 cells expressing CALM/AF10. 
$B R C A 1$ encodes a nuclear phosphoprotein that plays a role in maintaining genomic stability and acts as a tumor suppressor. It was initially identified as the gene mutated in families with early onset breast cancer (Futreal et al., 1994, Chen et al., 1996). The BRCA1 protein associates with other tumor suppressor proteins, DNA damage sensors, and signal transducers to form a large multi-subunit protein complex known as BASC for BRCA1-associated genome surveillance complex (Wang et al., 2000). BRCA1 muations are responsible for approximately $40 \%$ of familial breast cancers and for more than $80 \%$ of familial breast and ovarian cancers and it has recently been implicated as a predictive marker of poorer overall survival in sporadic ovarian cancer (Weberpals et al., 2009). It is tempting to speculate that the down-regulation of BRCA1 might play a role in the early stages of CALM/AF10-mediated oncogenesis by facilitating the accumulation of additional mutations which are necessary for the development of the full leukemic phenotype.

\section{$\boldsymbol{R A R A}$}

$R A R A$ (retinoic acid receptor, alpha) was another gene that was found to be up-regulated in this experiment. Translocations which involve the RARA gene are a cardinal feature of acute promyelocytic leukemia (APL) (Goddard et al., 1992), the most common of these translocations is the $\mathrm{t}(15 ; 17)(\mathrm{q} 21 ; \mathrm{q} 22)$, which fuses the $R A R A$ gene with the $P M L$ gene (Vitoux et al., 2007). The result of the different RARA fusions is a loss of wild type RARA function. Therefore, the significance of a higher expression of $R A R A$ in the context of leukemogenesis is not clear. It has been shown in gene profiling of colonic serrated adenomas by using oligonucleotide microarray that $R A R A$ is one of the three significantly up-regulated genes (Kim et al., 2008). In contrast, it has recently been reported that 
diminished RARA expression contributes to leukemogenesis in acute myeloid leukemia cell lines, though the regulation of expression of this gene was very complex and varies at different stages of the disease (Glasow et al., 2008).

\section{FOXP1}

Forkhead box transcription factors play important roles in the regulation of tissue- and cell type-specific gene transcription during both development and adulthood. One of these genes, FOXP1 (forkhead box P1), was found to be one of the immediate targets of CALM/AF10. The up-regulation of FOXP1 has also been associated with invasive breast carcinomas (Bates et al., 2008). It has also been reported that deregulation of FOXP1 expression (over-expression) plays an important role in lymphoma development (Goatly et al., 2008). Similarly, up-regulated mRNA expression of the FOXP1 forkhead transcription factor in response to normal B-cell activation and high expression in a poor prognosis subtype of diffuse large B-cell lymphoma (Banham et al., 2005) is an indication that this gene is one of the more interesting targets of CALM/AF10.

\section{PBXIP1}

PBXIP1 (pre-B-cell leukemia homeobox 1 interacting protein 1), also known as HPIP (hematopoietic PBX-interacting protein), was up-regulated upon the expression of CALM/AF10. $P B X 1$ is a transcription factor originally discovered as the chromosome 1 participant in the translocation $\mathrm{t}(1 ; 19)$ which results in the $\mathrm{E} 2 \mathrm{~A} / \mathrm{PBX} 1$ fusion protein, seen frequently in pediatric acute lymphoblastic leukemia (Kamps et al., 1990). HPIP interacts with $P B X 1$, which is a homeodomain protein that functions in complexes with other homeodomain-containing proteins to regulate gene expression during 
developmental and/or differentiation processes (Abramovich et al., 2000). Abramovich et al. (2000) showed that HPIP inhibits the ability of PBX1-HOX heterodimers to bind to target sequences and suggested that $H P I P$ is a new regulator of $P B X 1$ function (Abramovich et al., 2002).

\subsection{The $M L L$ gene family}

$M L L$ (myeloid/lymphoid or mixed-lineage leukemia (trithorax homolog, Drosophila)) is a frequent target for recurrent translocations in acute leukemias that may be characterized as acute myeloid leukemia, acute lymphoblastic leukemia (ALL), or mixed lineage (biphenotypic) leukemia (MLL) (Krivtsov and Armstrong, 2007). Leukemias with translocations involving $M L L$ possess unique clinical and biologic characteristics and are often associated with poor prognosis (Krivtsov and Armstrong, 2007). MLL rearrangements are found in more than $70 \%$ of infant leukemias, where the immunophenotype is more consistent with ALL or AML-M6, but are less frequent in leukemias from older children. $M L L$ translocations are also found in approximately $10 \%$ of AMLs in adults (Matthew et al., 2008), as well as in therapy-related leukemias, that develop in patients previously treated with chemotherapeutic agents (mainly topoisomerase II inhhibitors) for other malignancies (Millot et al., 2005). A key feature of MLL fusion proteins is their high efficiency in transforming hematopoietic cells (Krivtsov and Armstrong, 2007). The $M L L$ gene encodes a DNA-binding protein that methylates histone $\mathrm{H} 3$ lys4 (H3K4) and positively regulates expression of target genes, notably multiple $H O X$ genes (Ansari et al., 2008). MLL-like genes are part of the trithorax-polycomb system which is crucial in maintaining gene expression patterns established during developmental processes (epigenetic memory). 
In the current experiment, two members of the MLL gene family (MLL3 and MLL5) were found to be up-regulated. MLL3 encodes a nuclear protein and has not yet been associated with malignancies while MLL5 has been shown to upregulated in certain subsets of myeloid leukemias (Emerling et al., 2002). Though the role of MLL5 overexpression in cell cycle regulation has been reported (Deng et al., 2004, Cheng et al., 2008), additional functional studies are required to assess the role of $M L L 3$ or $M L L 5$ upregulation in CALM/AF10-mediated leukemogenesis.

\subsection{Important Signalling Pathways are Affected by CALM/AF10}

\subsubsection{Notch signaling}

Notch signaling is one of the most important pathways in the cell and controls differentiation and proliferation in various cell types and is associated with several diseases (Karlsson et al., 2008). The Notch family of evolutionarily conserved proteins regulates a broad spectrum of cell-fate decisions and differentiation processes during fetal and post-natal development. The best characterized role of Notch signaling during mammalian hematopoiesis and lymphopoiesis is the essential function of the Notch1 receptor in T-cell lineage commitment. More recent studies have addressed the roles of other Notch receptors and ligands, as well as their downstream targets, revealing additional novel functions of Notch signaling in intra-thymic T-cell development, B-cell development and peripheral T-cell function. It has been shown that more than $50 \%$ of human T-ALLs, including tumors from all major molecular oncogenic subtypes, have activating mutations that involve the extracellular heterodimerization domain and/or the C-terminal PEST domain of NOTCH1 (Weng et al., 2004). Importantly, the CALM/AF10 fusion gene is most frequent fusion gene in T-ALL with T-cell receptor $\gamma / \delta$ 
rearrangements, being present in $20 \%$ of the cases. Aberrant Notch signaling has also been found in other neoplastic and non-neoplastic conditions like osteoarthritis (Karlsson et al., 2008), melanoma (Bedogni et al., 2008) and mesothelioma (Graziani et al., 2008).

In this study, it was observed that one of the positive regulators of Notch signaling, MAML3 (mastermind-like 3 (Drosophila)), is significantly up-regulated. Mastermind (Mam) is one of the evolutionarily conserved elements of the Notch signaling pathway. The Drosophila gene mastermind is an important positive regulator of the pathway (Lin et al., 2002). Lin et al. (2002) discussed that both MAML2 and MAML3 stabilize and are part of the DNA-binding complex containing RBP-J/CBF-1 and the Notch intracellular domain, which assembles at the promoter of Notch target genes. It is very likely that MAML3-mediated Notch activation plays a role in CALM/AF10-mediated leukemogenesis since all CALM/AF10 positive patients (both AML and ALL) have a TCR $\gamma / \delta$ rearrangement. In addition, we observed that $N O T C H 1$ itself is up-regulated in CALM/AF10 patients using microarray analysis (unpublished data).

\subsection{DNA damage check-point and DNA repair}

Interestingly, several genes involved in DNA damage sensing, DNA damage check-point and DNA repair were found deregulated after expression of CALM/AF10. Most of these genes were found to be down-regulated.

One of the very interesting genes in the DNA damage check-point pathway is ATM (ataxia telangiectasia mutated), a gene that belongs to the PI3/PI4-kinase family and plays an important role in cell cycle control after DNA damage. This gene was found to be significantly up-regulated. Mutations in the $A T M$ gene lead to Ataxia teleangiectasia, a 
recessive autosomal disease characterized by cerebellar ataxia (progressive difficulty in walking and other movements), teleangiectasia (dilatation of small arteries) and immunodeficiency. It is also characterized by increasing sensitivity to radiations and by a high probability of developing leukemias or other tumours.

$A T M$ functions as a regulator of a wide variety of downstream proteins, including tumor suppressor proteins like TP53 and BRCA1, the checkpoint kinase CHK2, the checkpoint proteins RAD17 and RAD9, and the DNA repair protein NBS1 (Antoccia et al., 2008). ATM is crucial for the maintenance of chromosomal integrity. The absence of ATM kinase activity may lead to the rapid accumulation of irreversible chromosome damage (White et al., 2008). Mutations and deletions of ATM are frequently found in chronic lymphocytic leukema (CLL) (Wei et al., 2008) and childhood malignancies (Fabienne et al., 2008). Some findings also suggest that overexpression of $A T M$ may be one of the early events in the carcinogenesis of oral squamous cell carcinoma (He et al., 2008). It has been reported that there is an increased need for ATM signaling for double strand break and repair as the heterochromatic component of a genome expands (Goodarzi et al., 2008). Choo and co-workers showed that $A T M$ can signal to cyclin D1, a key molecule for transition between the G1 and S phases of the cell-cycle with pivotal roles in the development of several human cancers, may be required for maintenance of genomic integrity achieved by rapid arrest of the cell-cycle and that disruption of this crosstalk may increase susceptibility to cancer (Choo et al., 2009).

Down-regulation of $D D B 2$ (damage-specific DNA binding protein 2), a gene involved in cellular response to DNA damage with a direct DNA binding activity (Kulaksiz et al., 2005), is also interesting as it further signifies the impact that CALM/AF10 might have in 


\section{Discussion}

DNA damage and repair. Interestingly, $B R C A 1$ upregulates $D D B 2$, with some evidence of P53 involvement in its regulation (El-Deiry, 2002), via interactions with the RAD51 protein family. Interestingly, RAD51 (RAD51 homolog (RecA homolog, E. coli) (S. cerevisiae)) was found to be down-regulated in the current data. The interaction between RAD51 and BRCA1/BRCA2 was found to be important for the cellular response to DNA damage results indicate that alterations in $R A D 51$ activity may contribute to the disturbances of DNA repair involving $R A D 51$ and/or $B R C A 2$ penetration and thus enhance the risk of breast cancer development (Maria et al., 2008). The association of RAD51 and the BRCAs has been credited to CHEK1 (another down-regulated gene in this study) and CHEK2 (Bahassi et al., 2008).

Up-regulation of $A T M$ and differential regulation of various genes involved in genomic stability and DNA damage repair in the current study indicate that CALM/AF10 expression might induces genomic instability and thereby affecting DNA break and repair pathways which in turn might lead to cell cycle arrest.

\subsection{Cell cycle is one of the most dramatically affected pathways by}

\section{CALM/AF10}

The connection between cell cycle control and cancer is quite obvious. The cell cycle machinery controls cell proliferation, and cancer is a disease of inappropriate cell proliferation (Collins et al., 1997). Fundamentally, all cancers permit the existence of too many cells. However, this excess number of cells is linked in a vicious cycle with a reduction in sensitivity to signals that normally tell a cell to adhere, differentiate, or die (Collins et al., 1997). At least two types of cell cycle control mechanisms are recognized: 
a cascade of protein phosphorylations (involving a highly regulated kinase family) that are important for the progression from one stage of the cell cycle to the next, and a set of checkpoints that monitor completion of critical events and delay progression to the next stage if necessary (Collins et al., 1997).

In this study, cell cycle was found to be one of the most dramatically affected pathways by CALM/AF10 which may be as a result of the significant impact of the fusion gene on DNA damage checkpoint genes (ATM being the checkpoint that mediates DNA damage checkpoint and cell cycle as discussed in the previous section). As can be noted from the pathway analysis (see results section on Pathway analysis sub-section Cell cycle), a significant proportion of the genes in cell cycle (approx. 50\%) are deregulated.

Another entry point into the cell cycle from other pathways is via $S M A D 2 / 3$, which mediate the link between TGF $\beta$ signaling and cell cycle, playing a role in cellular proliferation, apoptosis, actin cytoskeleton regulation, cell motility, transcription, and Ras or insulin signaling (Brown et al., 2008). The SMAD genes SMAD2 and SMAD3 were significantly up-regulated in the current study. Aberrant expression of SMAD2 plays a role in hepatocellular carcinoma (Wu et al., 2007) and its up-regulation has been associated with Glioma (Bruna et al., 2007). It has also been reported that breast cancer patients with high expression of SMAD2 tended to have a better prognosis (Liapis et al., 2007).

The combined impact of DNA damage checkpoint and TGF $\beta$ signaling via ATM/ATR and $S M A D 2 / 3$, respectively, seems to indirectly lead to cell cycle arrest as most of the critical 


\section{Discussion}

positive regulators of cell cycle are down-regulated in CALM/AF10 expressing DG-75 cells.

\subsection{Genes close to the breakpoint of either AF10 or CALM are not}

\section{immediate targets of CALM/AF10}

In a microarray-based comparison of CALM-AF10+ T-ALL to CALM-AF10- T-ALL, it was reported that the genes located close to AF10 breakpoint of $t(10 ; 11)(p 13 ; q 14-21)$ (DNAJC1, COMMD3, BMI1 and SPAG6) were found to be significantly up-regulated (Dik et al., 2005). In our CALM/AF10 patient microarray data set (section 3.4.7.), we were able to confirm that these genes were up-regulated (unpublished data). Interestingly, these genes were also found to be up-regulated in a CALM/AF10 mouse bone marrow transplantation model (except Spag6) despite the fact that these mice do not have the $\mathrm{t}(10 ; 11)(\mathrm{p} 13 ; \mathrm{q} 14-21)$ translocation (unpublished data), implying that the up-regulation of these genes might be due to the direct/indirect impact of the expression of CALM/AF10 and not as a consequence of the translocation event.

We analyzed the expression levels of these genes (DNAJC1, COMMD3, BMI1 and $S P A G 6$ ) in the current data set. None of these genes was found to be statistically significantly deregulated, indicating that they might be intermediate-late targets of CALM/AF10 or that strong repressive chromatin modifications are present at the these genes in the DG75 cell line. 


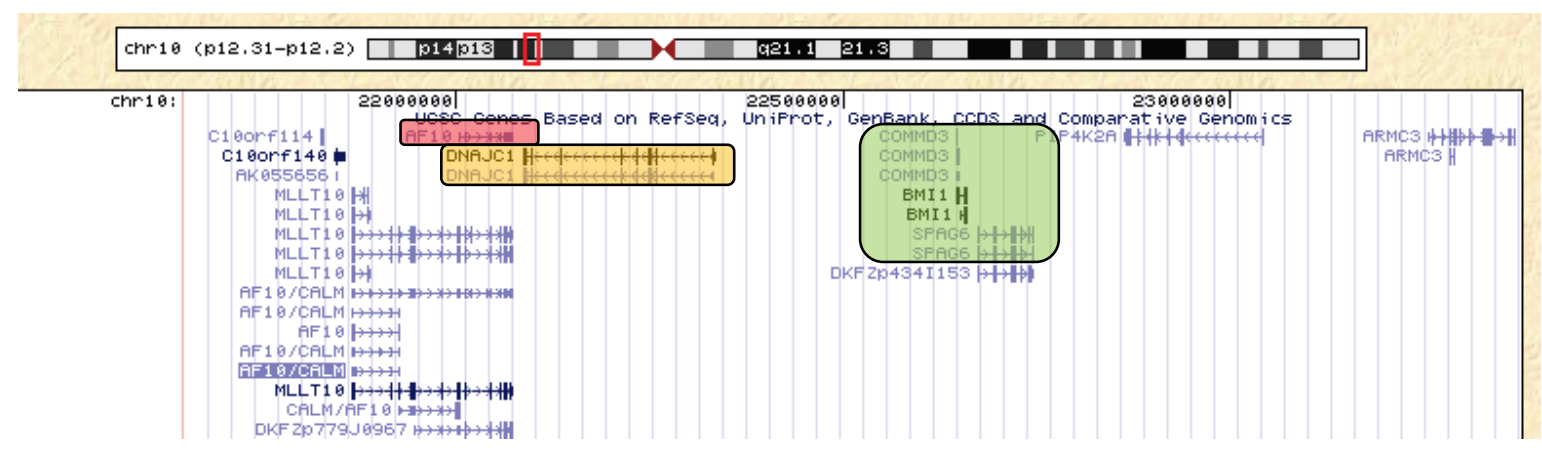

Figure 4.2. Location of AF10 and proximal genes that were analyzed ( $\pm 500 \mathrm{kbp})$

\subsection{Genomic instability and DNA repair might be the oncogenic pathway}

\section{of CALM/AF10 as revealed by comparative pathway analysis of patient}

\section{and cell line data}

It has been widely reported that genomic instability is one of the key features of malignancies. For instance, cases of ETP (Early T-cell Precursors)-ALL showed increased genomic instability, in terms of number and size of gene lesions, compared with those with typical T-ALL (Coustan-Smith et al., 2009). Similar results were also reported in proB acute lymphoblastic leukemia (Bumbea et al., 2007). The possible involvment of DNA damage and aberrant repair associated with internal tandem duplication of FLT3 (FLT3/ITD) for poor prognosis in AML (Sallmyr et al., 2008) indicates that genomic instability may play a pivotal role in disease progression of AML. The role of genomic instability and the probable causes and consequences has recently been reviewed (Annahita et al., 2008). Annahita and co-workers stated that disease progression in myeloid malignancies results from the accumulation of "mutations" in genes that control cellular growth and differentiation but also pointed out that the mechanism(s) by which these cells acquire genetic alterations or genomic instability is 
less well understood. In reference to DNA-microarray and real-time PCR based expression profiling studies, a recent review also indicated that deviant gene expression patterns in acute myeloid leukemias should be assessed on the background of gene expression levels of housekeeping functions, particular differentiation stages and epiphenomena due to genomic instability (Oyan et al., 2007).

Using the Gene Set Enrichment Analysis (GSEA) we could clearly show that DNA repair and genomic stability related pathways are significantly affected in both the CALM/AF10 patients' microarray data and in the microarray data of the DG-75 cell line after CALM/AF10 expression. It was also observed that the genomic stability and DNA repair genes that are differentially regulated in the two different settings were not the same, indicating that early targets (cell line data) might be different from those found in patients. This might be explained by the difference in the nature of the samples in that what is observed in the cell line we see the immediate impact of CALM/AF10 in a very controlled setting while in the CALM/AF10 positive patient samples the microarray study would detect late or terminal targets. It should also be noted that in the patient microarray study, the samples are compared with other types of leukemia and normal bone marrow, which might not be the ideal controls. Despite the huge differences in the systems used (controlled cell line system versus "messy" patient samples) and the different comparisons made (induced versus uninduced, and CALM/AF10-posistive versus other leukemia), it was still observed that CALM/AF10 affects genomic stability. This indicates that alterations of genomic stability might be one of the very important pathways in CALM/AF10 mediated leukemogenesis. 


\section{Summary}

The $\mathrm{t}(10 ; 11)(\mathrm{p} 12 ; \mathrm{q} 14)$ is a recurring chromosomal translocation that is found in acute myeloid and acute lymphoblastic leukemia as well as in malignant lymphoma. This translocation results in the fusion of $A F 10$, encoding a putative zinc finger transcription factor containing an N-terminal LAP/PHD zinc finger motif, a nuclear localization signal, an AT-hook domain, and a leucine zipper and with the CALM gene (Clathrin assembly protein lymphoid myeloid leukemia gene) that encodes a clathrin assembly protein. In the monocytic cell line U937 both the CALM/AF10 and the AF10/CALM fusion mRNAs can be identified. The CALM/AF10 fusion mRNA codes for the CALM/AF10 fusion protein which contains almost the complete CALM protein fused in frame to about $90 \%$ of the AF10 protein without the $\mathrm{N}$ terminal plant homeo domain (PHD) domain. CALM/AF10 is highly leukemogenic with its expression in primary bone marrow cells leading to the development of an aggressive acute leukemia with a short latency of 10 weeks in a murine bone marrow transplant model. We set out to identify immediate target genes of CALM/AF10. The fusion gene was cloned into pRTS-1, an episomally replicating tetracycline/doxycycline inducible (tet-on) expression vector. The construct was stably transfected into the Burkitt's lymphoma B cell line DG75. The expression of CALM/AF10 after induction was confirmed by RT-PCR. Gene expression profiling experiments were conducted using the Affymetrix ${ }^{\circledR}$ Human Genome U133 Plus 2.0 Array analyzing non-induced and induced (24 and 72 hours after induction) samples. As controls, DG75 cells transfected with the pRTS-1 vector without the CALM/AF10 fusion gene were used. The results were analyzed using the $\mathrm{R}$ statistical package and dChip (DNA Chip Analyzer) software. The expression of 1237 genes was found to be changed at least 2 fold 24 hours after the induction of CALM/AF10. 594 (48\%) genes were downregulated, while 643 (52\%) were upregulated. Downregulated genes included genes involved in DNA repair (DDB2, TOP2A, BRCAI), cell cycle check point control (CCNE2, CHEK1, CDC2), and chromosome maintenance (MCM3, MCM7, MCM10). Upregulated genes included signal transduction molecules like RAB8B (a member of the $R A S$ oncogene family) and STAT family members (STAT1 and STAT2), chromatin 
remodeling factors like $B A Z 2 A$ (bromodomain adjacent to zinc finger domain, $2 \mathrm{~A}$ ), and MAML3 (master mind like 3), a positive regulator of Notch signaling. A pathway analysis using KegArray showed an enrichment of differentially regulated genes in processes like "cell cycle regulation" and "DNA replication and repair". Interestingly, no significant upregulation of Hox genes was observed, as was previously reported in a study of CALM/AF10 positive patient samples (Dik et al., 2005). The changes in the expression levels of some selected genes were confirmed using a Taqman ${ }^{\circledR}$ Low Density Array (LDA). This analysis showed a statistically significant correlation $(r=0.78, p=0.001)$ between the real time PCR results and the expression levels obtained from the Affymetrix arrays. A gene set enrichment analysis, comparing the data obtained after inducible expression of CALM/AF10 in DG75 cells and data obtained from gene expression profiling in CALM/AF10-positive patient samples, showed a significant deregulation of genes involved in DNA repair and genomic stability both in the differentially regulated genes in the cell line experiments and in the patient data. Our results demonstrate that the expression of the leukemogenic CALM/AF10 fusion protein leads to a severe deregulation of critical cellular processes, and we could identify candidate genes as direct target of the CALM/AF10 fusion protein. 


\section{Zusammenfassung}

Die $\mathrm{t}(10 ; 11)(\mathrm{p} 12 ; \mathrm{q} 14)$ ist eine wiederkehrende chromosomale Translokation, die man bei der akuten myeloischen und akuten lymphoblastischen Leukämie (AML/ALL) und auch bei malignen Lymphomen findet. Diese Translokation führt zu einer eine Fusion des AF10-Gens, mit dem CALM Gen. AF10 kodiert einen putativen Zinkfinger-Transkriptionsfaktor, welcher ein N-terminales LAP/PHD Zink-Fingermotiv, ein nukleäres Lokalisationssignal, ein AT-Hook und ein Leucinzipper enthält. CALM hingegen kodiert das Clathrin Assembly Lymphoid Myeloid Leukemia Protein und spielt bei der rezeptorvermittelten Endozytose eine wichtige Rolle. In der monozytischen Zelllinie U937 konnten die $m R N A s$, die für CALM/AF10- und AF10/CALM-Fusionsproteine kodieren, identifiziert werden. Die CALM/AF10 mRNA beinhaltet fast das komplette CALM-Gen, an das fast $90 \%$ des offenen Leserahmens des $A F 10$-Gens anschließen. Lediglich die N-terminale PHD-Domäne des AF10-Gens fehlt in dieser Fusions- $m R N A$.

Die Expression eines CALM/AF10 Fusionproteins in primären Knochenmarkszellen ist hochgradig leukämogen im Maus-Transplantationsmodell, da nach einer sehr kurzen Latenzzeit von nur 10 Wochen eine akuten Leukämie in den Mäusen diagnostizierbar ist.

Ziel dieser Arbeit war es, bisher unbekannte, früher Zielgene des CALM/AF10-Fusionsproteins zu identifizieren. Dazu wurde das Fusions-Gen in den episomalen pRTS-1 Vektor einkloniert, dessen Promotor mit Hilfe des Tetrazyklin-Derivats Doxyzyklin conditional aktivierbar ist (Tet-on System). Dieses Kontrukt wurde dann in die Burkitt-Lymphomzelllinie DG75 stabil transfiziert und die Expression von CALM/AF10 nach Induktion des Vektors mittels RT-PCR überprüft. Als Negativkontrolle dienten DG75 Zellen, die mit einem pRTS-1 Vektor ohne Fusionsgen stabil transfiziert worden waren. Mit Hilfe des Genchips Affymetrix ${ }^{\circledR}$ hgU133 plus 2.0 wurden Genexpressionsprofile erstellt. Um zwischen frühen und späten effekten der CALM/AF10 Expression unterscheiden zu können, wurden Genchipanalysen zu unterschiedlichen Zeitpunkten (24h und 72h nach Vektorinduktion) durchgeführt.

Die statistische Datenanalyse des Genexpressionsprofil wurde mit Hilfe der Software "R" und der dCHip Software durchgeführt und ergab folgende Ergebnisse: 24 Stunden nach der Induktion von CALM/AF10 hatte sich das Expressionsniveau von 1237 Genen um mindestens das 2 fache des Ausgangswertes verändert. Bei 594 Genen (=48\%) erniedrigte sich das Expressionniveau, im Gegensatz zu 643 Genen $(=52 \%)$, deren Expressionsniveau sich erhöhte. Unter den Genen, deren Expressionniveau sich erniedrigte, fanden sich Schlüsselgene der DNA-Reparatur (DDB2, TOP2A, BRCA1), der Zellzykluskontrolle (CCNE2, CHEK1, CDC2) und der Chromosomen-Stabilität (MCM3, MCM7, MCM10). Hochregulierte Gene kodierten für Signaltransduktionsmoleküle wie RAB8B (ein Mitglied der RAS Onkogen-Familie), Chromatin-Remodelling Faktoren wie BAZ2A (bromodomain adjacent to zinc finger domain, 2A), (STATFamilienmitglieder (STAT1 und STAT2) und MAML3 (mastermind like 3), das den Notch-Signalweg positiv 
reguliert. Die Einordnung der differenziert regulierten Gene in Signalwegskaskaden mittels KegArray zeigte eine Anreicherung der differentiell regulierten Gene im Kategorien wie "Zellzyklusregulation" und "DNA-Replikation und Reparatur". Einen Anstieg des Expressionsniveaus der Hox Gene konnte jedoch nicht beobachtet werden, obwohl dies zuvor in einer Patientenstudie gefunden wurde (Dik et al., 2005). Zur Verifizierung der gefundenen Ergebnisse wurden die Veränderungen im Expressionsniveau einiger zuvor ausgewählter Gene mittels Taqman ${ }^{\circledR}$ Low Density Array (LDA) bestätigt. Dabei zeigte sich eine statistisch-signifikante Korrelation $(r=0.78, \mathrm{p}=0.001)$ zwischen den Realtime-PCR-Ergebnissen und den mittels Affymetrix-Array ermittelten Veränderungen im Expressionsniveaus der einzelnen Gene. Eine Gene Set Enrichment Analyse zeigte zudem, dass Gene, die bei der DNA-Reparatur und der genomischen Stabilität eine Rolle spielen, sowohl bei bei den deregulierten Genen in unserem Zellliniensystem als auch bei den differentiell regulierten Genen bei CALM/AF10-positiven Patienten signfikant überrepräsentiert sind. Zusammenfassend zeigen unsere Untersuchungen, dass die Expression des leukämogenen Fusionsproteins CALM/AF10 zu einer starken Deregulierung von Schlüsselgenen in kritischen, zellulären

Prozessen führt, und wir konnten somit erste Kandidaten-Gene für frühe Zielgene des CALM/AF10 Fusionsproteins ermitteln. 


\section{References}

Abramovich, C., Shen, W.-F., Pineault, N., Imren, S., Montpetit, B., Largman, C. and Humphries, R. K. (2000). Functional Cloning and Characterization of a Novel Nonhomeodomain Protein That Inhibits the Binding of PBX1-HOX Complexes to DNA. J. Biol. Chem., 275, 26172-26177.

Abramovich, C., Chavez, E. A., Lansdorp, P. M. and Humphries, R. K. (2002). Functional characterization of multiple domains involved in the subcellular localization of the hematopoietic Pbx interacting protein (HPIP). Oncogene, 21, 6766-6771.

Affymetrix (2005). Eukaryotic Sample and Array Processing.

Anika Meyerholz, L. H. S. G. P.-C. E. G. B. E. J. U. (2005). Effect of Clathrin Assembly Lymphoid Myeloid Leukemia Protein Depletion on Clathrin Coat Formation. Traffic, 6, 1225-1234.

Annahita, S., Jinshui, F. and Feyruz Virgilia, R. (2008). Genomic instability in myeloid malignancies: Increased reactive oxygen species (ROS), DNA double strand breaks (DSBs) and error-prone repair. Cancer Letters, 270, 1-9.

Ansari, K. I., Mishra, B. P. and Mandal, S. S. (2008). Human CpG binding protein interacts with MLL1, MLL2 and hSet1 and regulates Hox gene expression. Biochimica et Biophysica Acta (BBA) - Gene Regulatory Mechanisms, 1779, 6673.

Antoccia, A., Sakamoto, S., Matsuura, S., Tauchi, H. and Komatsu, K. (2008). NBS1 Prevents Chromatid-Type Aberrations through ATM-Dependent Interactions with SMC1. Radiation Research, 170, 345-352.

Aplan, P. D. (2006). Causes of oncogenic chromosomal translocation. Trends Genet, 22, 46-55.

Ashihara, E., Nakamura, S., Inaba, T., Taki, T., Hayashi, Y. and Shimazaki, C. (2007). A novel AF10-CALM fusion transcript in g/d-T cell type lymphoblastic lymphoma. American Journal of Hematology, 82, 859 - 860.

Bahassi, E. M., Ovesen, J. L., Riesenberg, A. L., Bernstein, W. Z., Hasty, P. E. and Stambrook, P. J. (2008). The checkpoint kinases Chk1 and Chk2 regulate the 


\section{References}

functional associations between hBRCA2 and Rad51 in response to DNA damage. Oncogene, 27, 3977-3985.

Banham, A. H., Connors, J. M., Brown, P. J., Cordell, J. L., Ott, G., Sreenivasan, G., Farinha, P., Horsman, D. E. and Gascoyne, R. D. (2005). Expression of the FOXP1 Transcription Factor Is Strongly Associated with Inferior Survival in Patients with Diffuse Large B-Cell Lymphoma. Clin Cancer Res, 11, 1065-1072.

Barski, A., Cuddapah, S., Cui, K., Roh, T. Y., Schones, D. E., Wang, Z., Wei, G., Chepelev, I., Zhao, K. and 1Laboratory of Molecular Immunology, N. H., Lung (2007). High-Resolution Profiling of Histone Methylations in the Human Genome. Cell, 129, 823-837.

Bates, G., Fox, S., Han, C., Launchbury, R., Leek, R., Harris, A. and Banham, A. (2008). Expression of the forkhead transcription factor FOXP1 is associated with that of estrogen receptor $\beta$ in primary invasive breast carcinomas. Breast Cancer Research and Treatment, 111, 453-459.

Bedogni, B., Warneke, J. A., Nickoloff, B. J., Giaccia, A. J. and Powell, M. B. (2008). Notch1 is an effector of Akt and hypoxia in melanoma development. J. Clin. Invest., 118, 3660-3670.

Ben-Bassat, H., Goldblum, N., Mitrani, S., Goldblum, T., Yoffey, J. M., Cohen, M. M., Bentwich, Z., Ramot, B., Klein, E. and Klein, G. (1977). Establishment in continuous culture of a new type of lymphocyte from a "Burkitt like" malignant lymphoma (line D.G.-75). Int J Cancer, 19, 27-33.

Biosystems, A. (2003). Applied Biosystems 7900HT Micro Fluidic Card Getting Started Guide

Bornkamm, G. W., Berens, C., Kuklik-Roos, C., Bechet, J., Laux, G., Bachl, J., Korndoerfer, M., Schlee, M., Hölzel, M., Malamoussi, A., Chapman, R. D., Nimmerjahn, F., Mautner, J., Hillen, W., Bujard, H. and Feuillard, J. (2005). Stringent doxycycline-dependent control of gene activities using an episomal onevector system. Nucleic Acids Res., 33, e137.

Brown, K. A., Ham, A. J., Clark, C. N., Meller, N., Law, B. K., Chytil, A., Cheng, N., Pietenpol, J. A. and Moses, H. L. (2008). Identification of novel Smad2 and 
Smad3 associated proteins in response to TGF-beta1. Journal of Cellular Biochemistry, 105, 596-611.

Bruna, A., Darken, R. S., Rojo, F., Ocaña, A., Peñuelas, S., Arias, A., Paris, R., Tortosa, A., Mora, J., Baselga, J. and Seoane, J. (2007). High TGF²-Smad Activity Confers Poor Prognosis in Glioma Patients and Promotes Cell Proliferation Depending on the Methylation of the PDGF-B Gene. 11, 147-160.

Bumbea, H., Serghei, L., Vlădăreanu, A. M., Stefan, L. M., Casleanu, D., Voican, I. and Begu, M. (2007). Cryptic genomic abnormalities associated with coexpression of KOR-SA3544 and NG.2 in proB acute lymphoblastic leukemia. Rom $J$ Intern Med., 45, 387-391.

Caudell, D., Zhang, Z., Chung, Y. J. and Aplan, P. D. (2007). Expression of a CALMAF10 Fusion Gene Leads to Hoxa Cluster Overexpression and Acute Leukemia in Transgenic Mice. Cancer Res, 67, 8022-8031.

Caudell, D. and Aplan, P. D. (2008). The role of CALM-AF10 gene fusion in acute leukemia. Leukemia, 22, 678-685.

Chaplin, T., Ayton, P., Bernard, O. A., Saha, V., Della Valle, V., Hillion, J., Gregorini, A., Lillington, D., Berger, R. and Young, B. D. (1995). A novel class of zinc finger/leucine zipper genes identified from the molecular cloning of the $t(10 ; 11)$ translocation in acute leukemia. Blood, 85, 1435-1441.

Chen, Y., Farmer, A. A., Chen, C.-F., Jones, D. C., Chen, P.-L. and Lee, W.-H. (1996). BRCA1 Is a 220-kDa Nuclear Phosphoprotein That Is Expressed and Phosphorylated in a Cell Cycle-dependent Manner. Cancer Res, 56, 3168-3172.

Cheng, F., Liu, J., Zhou, S. H., Wang, X. N., Chew, J. F. and Deng, L.-W. (2008). RNA interference against mixed lineage leukemia 5 resulted in cell cycle arrest. The International Journal of Biochemistry \& Cell Biology, 40, 2472-2481.

Choo, D. W., Baek, H. J., Motoyama, N., Cho, K. H., Kim, H. S. and Kim, S. S. (2009). ATM is required for rapid degradation of cyclin D1 in response to [gamma]irradiation. Biochemical and Biophysical Research Communications, 378, 847850 .

Collins, K., Jacks, T. and Pavletich, N. P. (1997). The cell cycle and cancer. Proc. Natl.Acad. Sci. USA, 94, 2776-2778. 


\section{References}

Coustan-Smith, E., Mullighan, C. G., Onciu, M., Behm, F. G., Raimondi, S. C., Pei, D., Cheng, C., Su, X., Rubnitz, J. E., Basso, G., Biondi, A., Ching-Hon Pui, C.-H., Downing, J. R. and Campana, D. (2009). Early T-cell precursor leukaemia: a subtype of very high-risk acute lymphoblastic leukaemia. Lancet Oncology, 10, 147-156.

Deng, L.-W., Chiu, I. and Strominger, J. L. (2004). MLL 5 protein forms intranuclear foci, and overexpression inhibits cell cycle progression. Proc. Natl.Acad. Sci. USA, 101, 757-762.

Deshpande, A. J., Cusan, M., Rawat, V. P. S., Reuter, H., Krause, A., Pott, C., Quintanilla-Martinez, L., Kakadia, P., Kuchenbauer, F., Ahmed, F., Delabesse, E., Hahn, M., Lichter, P., Kneba, M., Hiddemann, W., Macintyre, E., Mecucci, C., Ludwig, W.-D., Humphries, R. K., Bohlander, S. K., Feuring-Buske, M. and Buske, C. (2006). Acute myeloid leukemia is propagated by a leukemic stem cell with lymphoid characteristics in a mouse model of CALM/AF10-positive leukemia. Cancer Cell, 10, 363-374.

Dik, W. A., Brahim, W., Braun, C., Asnafi, V., Dastugue, N., Bernard, O. A., van Dongen, J. J. M., Langerak, A. W., Macintyre, E. A. and Delabesse, E. (2005). CALM-AF10+ T-ALL expression profiles are characterized by overexpression of HOXA and BMI1 oncogenes. Leukemia, 19, 1948-1957.

Dreyling, M. H., Martinez-Climent, J. A., Zheng, M., Mao, J., Rowley, J. D. and Bohlander, S. K. (1996). The $t(10 ; 11)(p 13 ; q 14)$ in the U937 cell line results in the fusion of the AF10 gene and CALM, encoding a new member of the AP-3 clathrin assembly protein family. Proc. Natl.Acad. Sci. USA, 93, 4804-4809.

DSMZ (2008). DG-75.

El-Deiry, W. S. (2002). Transactivation of repair genes by BRCA1. Cancer Biol Ther., 1, 490-491.

Emerling, B. M., Bonifas, J., Kratz, C. P., Donovan, S., Taylor, B. R., Green, E. D., Le Beau, M. M. and Shannon, K. M. (2002). MLL5, a homolog of Drosophila trithorax located within a segment of chromosome band 7q22 implicated in myeloid leukemia. Oncogene, 21, 4849-4854. 
Fabienne, G.-P., Hulya, O., Mary, K.-B., David, R. B., Philippe, M. and AndrÃ@ C-Pascal, S. (2008). Detection of ATM gene deletion/duplication by multiplex ligationdependant probe amplification in childhood lymphoid malignancies: A report from the Children's Oncology Group. Leukemia research, 32, 1207-1213.

Futreal, P. A., Liu, Q., Shattuck-Eidens, D., Cochran, C., Harshman, K., Tavtigian, S., Bennett, L. M., Haugen-Strano, A., Swensen, J. and Miki, Y. (1994). BRCA1 mutations in primary breast and ovarian carcinomas. Science, 266, 120-122.

Glasow, A., Barrett, A., Petrie, K., Gupta, R., Boix-Chornet, M., Zhou, D.-C., Grimwade, D., Gallagher, R., von Lindern, M., Waxman, S., Enver, T., Hildebrandt, G. and Zelent, A. (2008). DNA methylation-independent loss of RARA gene expression in acute myeloid leukemia. Blood, 111, 2374-2377.

Goatly, A., Bacon, C. M., Nakamura, S., Ye, H., Kim, I., Brown, P. J., RuskoneFourmestraux, A., Cervera, P., Streubel, B., Banham, A. H. and Du, M.-Q. (2008). FOXP1 abnormalities in lymphoma: translocation breakpoint mapping reveals insights into deregulated transcriptional control. Mod Pathol, 21, 902-911.

Goddard, A. D., Borrow, J. and Solomon, E. (1992). A previously uncharacterized gene, PML, is fused to the retinoic acid receptor alpha gene in acute promyelocytic leukaemia. Leukemia, 6 Suppl 3, 117S-119S.

Goodarzi, A. A., Noon, A. T., Deckbar, D., Ziv, Y., Shiloh, Y., Löbrich, M. and Jeggo, P. A. (2008). ATM Signaling Facilitates Repair of DNA Double-Strand Breaks Associated with Heterochromatin. Molecular Cell, 31, 167-177.

Gould, J. (2005). HierarchicalClustering Documentation. Broad MIT, Graziani, I., Eliasz, S., De Marco, M. A., Chen, Y., Pass, H. I., De May, R. M., Strack, P. R., Miele, L. and Bocchetta, M. (2008). Opposite Effects of Notch-1 and Notch-2 on Mesothelioma Cell Survival under Hypoxia Are Exerted through the Akt Pathway. Cancer Res, 68, 9678-9685.

He, Y., Chen, Q. and Li, B. (2008). ATM in oral carcinogenesis: association with clinicopathological features. Journal of Cancer Research and Clinical Oncology, 134, 1013-1020. 
Irizarry, R. A., Bolstad, B. M., Collin, F., Cope, L. M., Hobbs, B. and Speed, T. P. (2003). Summaries of Affymetrix GeneChip probe level data. Nucl. Acids Res., 31, e15-.

Jones, B., Su, H., Bhat, A., Lei, H., Bajko, J., Hevi, S., Baltus, G. A., Kadam, S., Zhai, H., Valdez, R., Gonzalo, S., Zhang, Y., Li, E. and Chen, T. (2008). The Histone H3K79 Methyltransferase Dot1L Is Essential for Mammalian Development and Heterochromatin Structure. PLoS Genet. , 4, e1000190.

Kamps, M. P., Murre, C., Sun, X.-h. and Baltimore, D. (1990). A new homeobox gene contributes the DNA binding domain of the $\mathrm{t}(1 ; 19)$ translocation protein in pre-B all. Cell, 60, 547-555.

Kanehisa, M. and Goto, S. (2000). KEGG: Kyoto Encyclopedia of Genes and Genomes. Nucleic Acids Res., 28, 27-30.

Karlsson, C., Brantsing, C., Egell, S. and Lindahl, A. (2008). Notch1, Jagged1, and HES5 Are Abundantly Expressed in Osteoarthritis. Cells Tissues Organs, 188, 287-298.

Kim, K., Park, U., Wang, J., Lee, J., Park, S., Kim, S., Choi, D., Kim, C. and Park, J. (2008). Gene profiling of colonic serrated adenomas by using oligonucleotide microarray. International Journal of Colorectal Disease, 23, 569-580.

Klebig, M. L., Wall, M. D., Potter, M. D., Rowe, E. L., Carpenter, D. A. and Rinchik, E. M. (2003). Mutations in the clathrin-assembly gene Picalm are responsible for the hematopoietic and iron metabolism abnormalities in fit1 mice. Proc. Natl.Acad. Sci. USA, 100, 8360-8365.

Korsmeyer, S. (1992). Chromosomal translocations in lymphoid malignancies reveal novel proto-oncogenes. Ann Rev Immun, 10, 785-807.

Krivtsov, A. V. and Armstrong, S. A. (2007). MLL translocations, histone modifications and leukaemia stem-cell development. Nat Rev Cancer, 7, 823-833.

Kulaksiz, G., Reardon, J. T. and Sancar, A. (2005). Xeroderma Pigmentosum Complementation Group E Protein (XPE/DDB2): Purification of Various Complexes of XPE and Analyses of Their Damaged DNA Binding and Putative DNA Repair Properties. Mol. Cell. Biol., 25, 9784-9792. 
Laird, P. W. Z., A. Linders, K. Rudnicki, M. A. Jaenisch, R. and Berns, A. (1991). Simplified mammalian DNA isolation procedure. Nucleic Acids Research, 19, 4293.

Lamond, A. (2008). Establishing Stable Cell Lines. http://www.lamondlab.com/,

Levitan, D., Nanda, R., Rowley, J. and Olopade, O. (2003). Recurring Chromosome Rearrangements in Human Cancer. American Cancer Society, 6,

Li, C. and Wong, W. H. (2001). Model-based analysis of oligonucleotide arrays: model validation, design issues and standard error application. Genome Biology, 2, 1-11.

Li, C. and Wong, W. H. (2003). DNA-Chip Analyzer (dChip). Springer, 120-141.

Li, H., Ilin, S., Wang, W., Duncan, E. M., Wysocka, J., Allis, C. D. and Patel, D. J. (2006). Molecular basis for site-specific read-out of histone H3K4me3 by the BPTF PHD finger of NURF. Nature, 442, 91-95.

Liapis, G., Mylona, E., Alexandrou, P., Giannopoulou, I., Nikolaou, I., Markaki, S., Keramopoulos, A. and Nakopoulou, L. (2007). Effect of the different phosphorylated Smad2 protein localizations on the invasive breast carcinoma phenotype. Apmis, 115, 104-114.

Lieber , M., Raghavan , S. and Yu, K. (2008). Mechanistic Aspects of Lymphoid Chromosomal Translocations. J Natl Cancer Inst Monogr, 39, 8-11.

Lin, S.-E., Oyama, T., Nagase, T., Harigaya, K. and Kitagawa, M. (2002). Identification of New Human Mastermind Proteins Defines a Family That Consists of Positive Regulators for Notch Signaling. J. Biol. Chem., 277, 50612-50620.

Linder, B., Newman, R., Jones, L. K., Debernardi, S., Young, B. D., Freemont, P., Verrijzer, C. P. and Saha, V. (2000). Biochemical analyses of the AF10 protein: the extended LAP/PHD-finger mediates oligomerisation. Journal of Molecular Biology, 299, 369-378.

Lodish, H., Berk, A., Matsudaira, P., Kaiser, C. A., Krieger, M., Scott, M. A., Zipursky, L. and Darnell, J. (2003). Molecular Cell Biology. W.H. Freeman \& Company, Lynne V. Abruzzo, L. V., Lee, K. Y., Fuller, A., Silverman, A., Keating, M. J., Medeiros, L. J. and Coombes, K. R. (2005). Validation of oligonucleotide microarray data using microfluidic low-density arrays: a new statistical method to normalize realtime RT-PCR data. Biotechniques, 38, 785-792. 


\section{References}

Maria, N.-Z., Magdalena, B., Hanna, R.-M., Andrzej, K. and Wanda, M. K. (2008). Loss of heterozygosity in the RAD51 and BRCA2 regions in breast cancer. Cancer detection and prevention, 32, 144-148.

Matthew, G., Raluca, Y., Constance, A. G. and Denise, A. S. B. (2008). Acute mixed lineage leukemia and a $\mathrm{t}(6 ; 14)(\mathrm{q} 25 ; \mathrm{q} 32)$ in two adults. Cancer genetics and cytogenetics, 185, 28-31.

Millenaar, F. F., Okyere, J., May, S. T., van Zanten, M., Voesenek, L. A. C. J. and Peeters, A. J. M. (2006). How to decide? Different methods of calculating gene expression from short oligonucleotide array data will give different results. $B M C$ Bioinformatics, 7, 1-16.

Millot, F., Brizard, F., Sorel, N., Preudhomme, C., Cividin, M., Guilhot, F. and Brizard, A. (2005). Therapy-related acute lymphoblastic leukemia with MLL rearrangement following treatment of Burkitt's leukemia. Leukemia and Lymphoma, 46, 925 - 927.

Nambiar, M., Kari, V. and Raghavan, S. C. (2008). Chromosomal translocations in cancer. Biochimica et Biophysica Acta (BBA) - Reviews on Cancer, In Press, Corrected Proof,

Narita, M., Shimizu, K., Hayashi, Y., Taki, T., Taniwaki, M., Hosoda, F., Kobayashi, H., Nakamura, H., Sadamori, N., Ohnishi, H., Bessho, F., Yanagisawa, M. and Ohki, M. (1999). Consistent detection of CALM-AF10 chimaeric transcripts in haematological malignancies with $\mathrm{t}(10 ; 11)(\mathrm{p} 13 ; \mathrm{q} 14)$ and identification of novel transcripts. British Journal of Haematology, 105, 928-937.

Okada, Y., Feng, Q., Lin, Y., Jiang, Q., Li, Y., Coffield, V. M., Su, L., Xu, G. and Zhang, Y. (2005). hDOT1L Links Histone Methylation to Leukemogenesis. Cell, 121, 167-178.

Okada, Y., Jiang, Q., Lemieux, M., Jeannotte, L., Su, L. and Zhang, Y. (2006). Leukaemic transformation by CALM-AF10 involves upregulation of Hoxa5 by hDOT1L. Nat Cell Biol, 8, 1017-1024.

Oyan, A. M., Bø, T. H., Jonassen, I., Ulvestad, E., Tore Gjertsen, B., Bruserud, O. and Kalland, K. H. (2007). Global gene expression in classification, pathogenetic 
understanding and identification of therapeutic targets in acute myeloid leukemia. Curr Pharm Biotechnol, 8, 344-354.

Peña, P. V., Davrazou, F., Shi, X., Walter, K. L., Verkhusha, V. V., Gozani, O., Zhao, R. and Kutateladze, T. G. (2006). Molecular mechanism of histone H3K4me3 recognition by plant homeodomain of ING2. Nature, 442, 100-103.

Rabbitts, T. (1991). Translocations, Master Genes, and Differences between the Origins of Acute and Chronic Leukemias. Cell, 67, 641-644.

Rowley, J. and Potter, D. (1976). Chromosomal banding patterns in acute nonlymphocytic leukemia. Blood, 47, 705-721.

Rowley, J. (2001). Chromosome translocations:dangerous liaisons revisited. NATURE REVIEWS, 1, 245-249.

Rowley, J. D. (1973). A new consistent chromosomal abnormality in chronic myelogenous leukemia identified by quinacrine fluorescence and Giemsa staining. Nature 1973. Nature, 243, 290-3.

S Ahle, S. and Ungewickell, E. (1986). Purification and properties of a new clathrin assembly protein. $E M B O J, \mathbf{5}, 3143-3149$.

Saha, V., Chaplin, T., Gregorini, A., Ayton, P. and Young, B. D. (1995). The leukemiaassociated-protein (LAP) domain, a cysteine-rich motif, is present in a wide range of proteins, including MLL, AF10, and MLLT6 proteins. Proc. Natl.Acad. Sci. USA, 92, 9737-9741.

Sallmyr, A., Fan, J., Datta, K., Kim, K.-T., Grosu, D., Shapiro, P., Small, D. and Rassool, F. (2008). Internal tandem duplication of FLT3 (FLT3/ITD) induces increased ROS production, DNA damage, and misrepair: implications for poor prognosis in AML. Blood, 111, 3173-3182.

Subramanian, A., Tamayo, P., Mootha, V. K., Mukherjee, S., Ebert, B. L., Gillette, M. A., Paulovich, A., Pomeroy, S. L., Golub, T. R., Lander, E. S. and Mesirov, J. P. (2005). Gene set enrichment analysis: A knowledge-based approach for interpreting genome-wide expression profiles. Proc. Natl.Acad. Sci. USA, 102, 15545-15550. 
Takei, K., Mundigl, O., Daniell, L. and De Camilli, P. (1996). The synaptic vesicle cycle: a single vesicle budding step involving clathrin and dynamin. J. Cell Biol., 133, 1237-1250.

Tebar, F., Bohlander, S. K. and Sorkin, A. (1999). Clathrin Assembly Lymphoid Myeloid Leukemia (CALM) Protein: Localization in Endocytic-coated Pits, Interactions with Clathrin, and the Impact of Overexpression on Clathrin-mediated Traffic. Mol. Biol. Cell, 10, 2687-2702.

Toedling, J., Schmeier, S., Heinig, M., Georgi, B. and Roepcke, S. (2004). MACAT MicroArray Chromosome Analysis Tool. Bioconductor package manual,

Vitoux, D., Nasr, R. and de The, H. (2007). Acute promyelocytic leukemia: new issues on pathogenesis and treatment response. Int J Biochem Cell Biol, 39, 1063-1070.

Wang, Y., Cortez, D., Yazdi, P., Neff, N., Elledge, S. J. and Qin, J. (2000). BASC, a super complex of BRCA1-associated proteins involved in the recognition and repair of aberrant DNA structures. Genes \& Development, 14, 927-939.

Weberpals, J., Garbuio, K., O'Brien, A., Clark-Knowles, K., Doucette, S., Antoniouk, O., Goss, G. and Dimitroulakos, J. (2009). The DNA repair proteins BRCA1 and ERCC1 as predictive markers in sporadic ovarian cancer. International Journal of Cancer, 124, 806-815.

Wei, X., Jian-Yong, L., Yu-Jie, W., Hui, Y., Qiu-Dan, S., Li, L., Lei, F. and Hong-Xia, Q. (2008). Prognostic significance of ATM and TP53 deletions in Chinese patients with chronic lymphocytic leukemia. Leukemia research, 32, 1071-1077.

White, J. S., Choi, S. and Bakkenist, C. J. (2008). Irreversible chromosome damage accumulates rapidly in the absence of ATM kinase activity. Cell Cycle, 7, 12771284.

Wu, S. K., Wang, B. J., Yang, Y., Feng, X. H., Zhao, X. P. and Yang, D. L. (2007). Expression of PTEN, PPM1A and P-Smad2 in hepatocellular carcinomas and adjacent liver tissues. World J Gastroenterol., 13, 4554-4559.

Yutaka MIURA, H. W., and Taiji KATO (1999). TBE, or not TBE; that is the question: Beneficial usage of tris-borate for obtaining a higher resolution of small DNA fragments by agarose gel electrophoresis. Nagoya Medical Journal, 31, 1-6. 


\section{Appendix}

\section{Appendix}

A1. Data obtained for Kill Curve Analysis (KCA)

\begin{tabular}{|c|c|c|}
\hline Concentration $(\mu \mathrm{g})$ & Percent Survival after 5 days & Reference total \\
\hline .50 & 75.00 & 100.00 \\
\hline .50 & 70.00 & 100.00 \\
\hline .50 & 73.00 & 100.00 \\
\hline .60 & 55.00 & 100.00 \\
\hline .60 & 60.00 & 100.00 \\
\hline .60 & 58.00 & 100.00 \\
\hline .70 & 44.00 & 100.00 \\
\hline .70 & 48.00 & 100.00 \\
\hline .70 & 45.00 & 100.00 \\
\hline .80 & 30.00 & 100.00 \\
\hline .80 & 32.00 & 100.00 \\
\hline .80 & 34.00 & 100.00 \\
\hline .90 & 10.00 & 100.00 \\
\hline
\end{tabular}




\begin{tabular}{ccc}
\hline .90 & 5.00 & 100.00 \\
\hline .90 & 5.00 & 100.00 \\
\hline 1.00 & 3.00 & 100.00 \\
\hline 1.00 & 4.00 & 100.00 \\
\hline 1.00 & 4.00 & 100.00 \\
\hline
\end{tabular}

A2. Test of Normality of the data using K-S (Kolmogorov-Smirnov) test.

\begin{tabular}{|c|c|c|c|c|c|c|c|}
\hline \multicolumn{3}{|c|}{ One-Sample Kolmogorov-Smirnov Test } & \multicolumn{5}{|c|}{ Concentration $(\mu \mathrm{g} / \mathrm{ml})$} \\
\hline Description & Statistic & 0.5 & 0.6 & 0.7 & 0.8 & 0.9 & 1 \\
\hline \multirow[t]{2}{*}{ Normal Parameters(a,b) } & Mean & 72.66 & 57.66 & 45.66 & 32 & 6.66 & 3.66 \\
\hline & Std. Deviation & 2.51 & 2.51 & 2.08 & 2 & 2.88 & 0.57 \\
\hline \multirow[t]{3}{*}{ Most Extreme Differences } & Absolute & 0.21 & 0.21 & 0.29 & 0.17 & 0.38 & 0.38 \\
\hline & Positive & 0.18 & 0.18 & 0.29 & 0.17 & 0.38 & 0.28 \\
\hline & Negative & -0.21 & -0.21 & -0.21 & -0.17 & -0.28 & -0.38 \\
\hline Kolmogorov-Smirnov Z & & 0.37 & 0.37 & 0.5 & 0.3 & 0.66 & 0.66 \\
\hline Asymp. Sig. (2-tailed) & & 0.99 & 0.99 & 0.95 & 0.99 & 0.76 & 0.76 \\
\hline
\end{tabular}




\section{Appendix}

A3. Result of ANOVA of different concentrations of puromycin kill-efficiency

\begin{tabular}{llllll}
\hline \hline Mortality & Sum of Squares & df & Mean Square & F & Sig. \\
\hline Between Concentrations & 11484.94 & 5 & 2296.99 & 464.56 & .000 \\
\hline Within Concentrations & 59.33 & 12 & 4.94 & \\
\hline Total & 11544.28 & 17 & & \\
\hline
\end{tabular}

A4. Independent comparison of different concentrations showing that increment in concentration of puromycin yielded significant increment in percentage of dead cells, except for the increment from 0.9 to $1 \mu \mathrm{g}$.

\begin{tabular}{|c|c|c|c|c|c|c|}
\hline \multirow[b]{2}{*}{ Concentration $(\mu \mathrm{g})$} & \multirow{2}{*}{$\begin{array}{l}\mathbf{N} \\
1\end{array}$} & \multicolumn{5}{|c|}{ Subset for alpha $=.05$} \\
\hline & & 2 & 3 & 4 & 5 & 1 \\
\hline .50 & 3 & 27 & & & & \\
\hline .60 & 3 & & 42 & & & \\
\hline .70 & 3 & & & 54 & & \\
\hline .80 & 3 & & & & 68 & \\
\hline .90 & 3 & & & & & 93 \\
\hline 1.00 & 3 & & & & & 96 \\
\hline Sig. & & 1.00 & 1.00 & 1.00 & 1.00 & .58 \\
\hline
\end{tabular}

Means for groups in homogeneous subsets are displayed.

a Uses Harmonic Mean Sample Size $=3$ 
A5. Calculated/estimated Probit Analysis model based on the mortality data collected

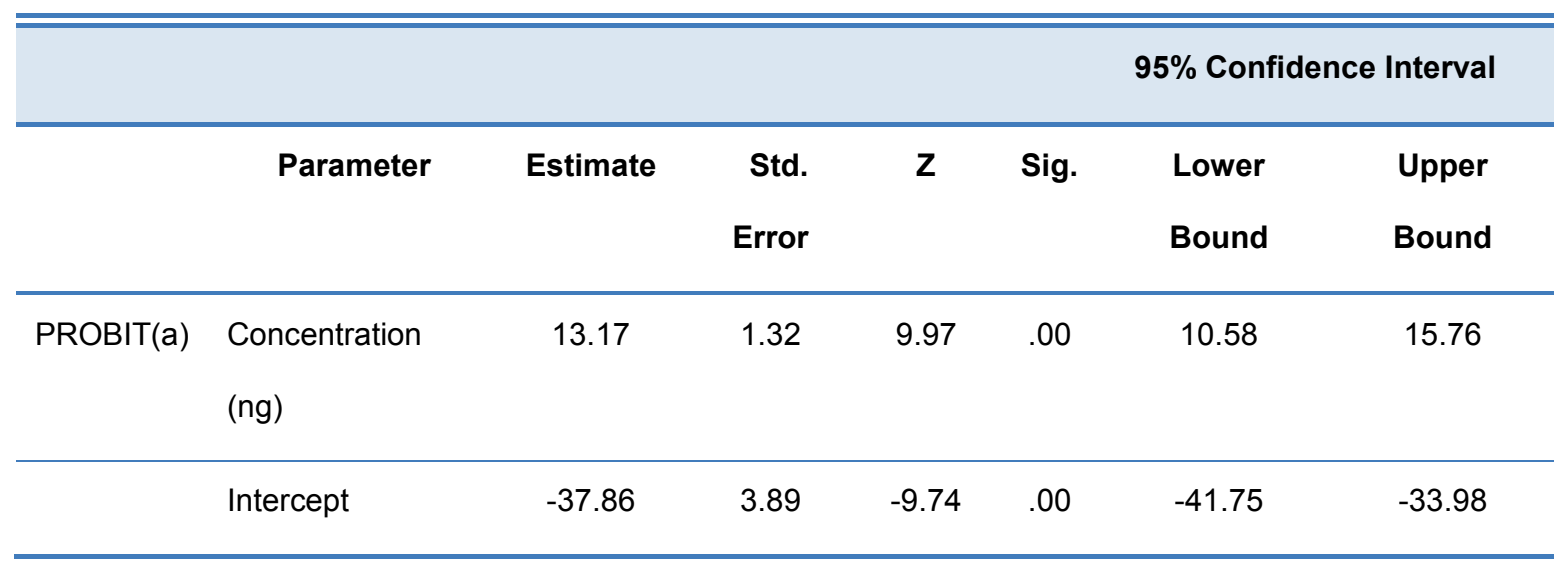

PROBIT model: PROBIT $(p)=$ Intercept + BX (Covariates $X$ are transformed using the base 10 logarithm.)

A6. Estimated kill probability (probit) for different puromycin concentration levels based on the mortality data collected.

\begin{tabular}{|c|c|c|c|c|c|c|c|}
\hline & \multirow[t]{3}{*}{ Probability } & \multicolumn{3}{|c|}{$\begin{array}{l}\text { 95\% Confidence Limits for } \\
\text { Concentration (ng) }\end{array}$} & \multicolumn{3}{|c|}{$\begin{array}{l}\text { 95\% Confidence Limits for } \\
\log (\text { Concentration (ng))(a) }\end{array}$} \\
\hline & & Estimate & Lower & Upper & Estimate & Lower & Upper \\
\hline & & & Bound & Bound & & Bound & Bound \\
\hline \multirow[t]{8}{*}{ PROBIT(b) } & .010 & 500.035 & 411.157 & 562.288 & 2.699 & 2.614 & 2.750 \\
\hline & .020 & 524.449 & 438.222 & 584.218 & 2.720 & 2.642 & 2.767 \\
\hline & .030 & 540.553 & 456.297 & 598.592 & 2.733 & 2.659 & 2.777 \\
\hline & .040 & 552.993 & 470.375 & 609.648 & 2.743 & 2.672 & 2.785 \\
\hline & .050 & 563.323 & 482.140 & 618.800 & 2.751 & 2.683 & 2.792 \\
\hline & .060 & 572.267 & 492.380 & 626.705 & 2.758 & 2.692 & 2.797 \\
\hline & .070 & 580.226 & 501.533 & 633.724 & 2.764 & 2.700 & 2.802 \\
\hline & .080 & 587.446 & 509.868 & 640.081 & 2.769 & 2.707 & 2.806 \\
\hline
\end{tabular}




\begin{tabular}{|c|c|c|c|c|c|c|}
\hline .090 & 594.091 & 517.566 & 645.922 & 2.774 & 2.714 & 2.810 \\
\hline .100 & 600.274 & 524.751 & 651.350 & 2.778 & 2.720 & 2.814 \\
\hline .150 & 626.564 & 555.535 & 674.362 & 2.797 & 2.745 & 2.829 \\
\hline .200 & 648.277 & 581.220 & 693.306 & 2.812 & 2.764 & 2.841 \\
\hline .250 & 667.504 & 604.139 & 710.054 & 2.824 & 2.781 & 2.851 \\
\hline .300 & 685.255 & 625.424 & 725.515 & 2.836 & 2.796 & 2.861 \\
\hline .350 & 702.126 & 645.742 & 740.227 & 2.846 & 2.810 & 2.869 \\
\hline .400 & 718.519 & 665.545 & 754.562 & 2.856 & 2.823 & 2.878 \\
\hline .450 & 734.743 & 685.175 & 768.816 & 2.866 & 2.836 & 2.886 \\
\hline .500 & 751.068 & 704.921 & 783.260 & 2.876 & 2.848 & 2.894 \\
\hline .550 & 767.755 & 725.052 & 798.178 & 2.885 & 2.860 & 2.902 \\
\hline .600 & 785.091 & 745.841 & 813.906 & 2.895 & 2.873 & 2.911 \\
\hline .650 & 803.420 & 767.582 & 830.891 & 2.905 & 2.885 & 2.920 \\
\hline .700 & 823.200 & 790.616 & 849.781 & 2.916 & 2.898 & 2.929 \\
\hline .750 & 845.093 & 815.364 & 871.592 & 2.927 & 2.911 & 2.940 \\
\hline .800 & 870.157 & 842.430 & 898.035 & 2.940 & 2.926 & 2.953 \\
\hline .850 & 900.312 & 872.949 & 932.179 & 2.954 & 2.941 & 2.969 \\
\hline .900 & 939.742 & 909.794 & 980.352 & 2.973 & 2.959 & 2.991 \\
\hline .910 & 949.522 & 918.507 & 992.806 & 2.978 & 2.963 & 2.997 \\
\hline .920 & 960.262 & 927.921 & 1006.674 & 2.982 & 2.968 & 3.003 \\
\hline .930 & 972.211 & 938.230 & 1022.313 & 2.988 & 2.972 & 3.010 \\
\hline .940 & 985.733 & 949.713 & 1040.248 & 2.994 & 2.978 & 3.017 \\
\hline .950 & 1001.383 & 962.802 & 1061.286 & 3.001 & 2.984 & 3.026 \\
\hline
\end{tabular}


Appendix

\begin{tabular}{lllllll}
.960 & 1020.089 & 978.206 & 1086.773 & 3.009 & 2.990 & 3.036 \\
\hline .970 & 1043.565 & 997.240 & 1119.218 & 3.019 & 2.999 & 3.049 \\
\hline .980 & 1075.610 & 1022.798 & 1164.216 & 3.032 & 3.010 & 3.066 \\
\hline .990 & 1128.126 & 1063.886 & 1239.456 & 3.052 & 3.027 & 3.093
\end{tabular}

a Logarithm base $=10$.

b A heterogeneity factor is used.

A7. Gene list and fold regulation (LDA and affymetrix)

\begin{tabular}{|c|c|c|}
\hline Gene & LDA & Affy \\
\hline MLF1 & 28.33257 & 4.525701 \\
\hline OAS1 & 28.17326 & 5.604744 \\
\hline IFI6 & 27.99181 & 4.231276 \\
\hline IFI44L & 21.87256 & 5.252087 \\
\hline CDC2 & 17.95673 & 3.569363 \\
\hline DHRS2 & 17.84711 & 3.650866 \\
\hline UNC13C & 16.83723 & 3.665108 \\
\hline BCL2A1 & 16.79263 & 3.633611 \\
\hline CKS1B & 16.21683 & 3.370275 \\
\hline OAS2 & 16.19548 & 3.287767 \\
\hline CDKN3 & 15.61251 & 3.681336 \\
\hline DNAJB1 & 14.01363 & 3.180718 \\
\hline HOXD10 & 13.82583 & 2.881668 \\
\hline TREX1 & 13.78496 & 3.351746 \\
\hline BIRC5;EPR1 & 13.76273 & 3.271797 \\
\hline LY9 & 13.38118 & 2.79076 \\
\hline
\end{tabular}




\section{Appendix}

\begin{tabular}{|c|c|c|}
\hline CCNB1 & 13.10304 & 3.242981 \\
\hline STAT1 & 12.89233 & 3.597469 \\
\hline RAP1A & 12.89008 & 3.33826 \\
\hline ANKRD39 & 12.76305 & 2.962647 \\
\hline DDB2 & 11.99111 & 2.063714 \\
\hline BIRC4BP & 11.95635 & 3.26541 \\
\hline ETV6 & 11.93008 & 2.786431 \\
\hline JMJD1A & 11.86804 & 2.920787 \\
\hline CDCA3 & 11.5734 & 2.970424 \\
\hline OTOF & 11.22087 & 4.623846 \\
\hline MZF1 & 10.96904 & 2.787606 \\
\hline SEPP1 & 10.94182 & 2.468817 \\
\hline CDC6 & 10.91783 & 3.035429 \\
\hline IRX5 & 10.88233 & 2.824842 \\
\hline SUV39H1 & 10.63244 & 2.76463 \\
\hline HBP1 & 10.50044 & 2.702757 \\
\hline SPBC24 & 10.48712 & 3.017905 \\
\hline MCM10 & 10.30153 & 2.881917 \\
\hline BCL2 & 10.26461 & 3.25085 \\
\hline JMJD2B & 10.25509 & 2.732236 \\
\hline ETV7 & 10.15794 & 2.881668 \\
\hline FHL2 & 10.15794 & 2.881668 \\
\hline HOXB3 & 10.15794 & 2.881668 \\
\hline
\end{tabular}


Appendix

\begin{tabular}{|c|c|c|}
\hline HOXD13 & 10.15794 & 2.881668 \\
\hline PBX1 & 10.15794 & 2.846048 \\
\hline PTN & 10.15794 & 2.881668 \\
\hline RAB8B & 10.15794 & 2.881668 \\
\hline WNT3 & 10.15794 & 2.507769 \\
\hline CDC25C & 9.973241 & 2.933275 \\
\hline DNAJB9 & 9.756624 & 2.87052 \\
\hline RECQL5 & 9.693124 & 2.667386 \\
\hline MAML3 & 9.544616 & 2.854931 \\
\hline CCNF & 9.529396 & 2.631359 \\
\hline TSGA10 & 9.517653 & 2.920866 \\
\hline METT10D & 9.460456 & 2.690977 \\
\hline JMJD2C & 9.414562 & 2.618284 \\
\hline RAD51 & 9.293371 & 2.677388 \\
\hline NEK2 & 9.236538 & 2.829051 \\
\hline RAD51AP1 & 9.216778 & 2.860128 \\
\hline PBXIP1 (HPIP) & 7.59870 & 10.202341 \\
\hline SMAD2/3 & 2.43180 & 9.546690 \\
\hline SKP2 & 9.189228 & 2.69633 \\
\hline FHL1 & 9.15025 & 3.21343 \\
\hline USP18 & 9.08962 & 3.175629 \\
\hline SKIL & 9.073743 & 2.612052 \\
\hline CREM & 8.990205 & 2.726596 \\
\hline
\end{tabular}




\section{Appendix}

\begin{tabular}{|c|c|c|}
\hline KIF23 & 8.650458 & 2.885807 \\
\hline $\mathrm{IF|} 27$ & 8.543739 & 2.089735 \\
\hline MAP4K3 & 8.524462 & 2.70185 \\
\hline CHEK1 & 8.514601 & 2.706704 \\
\hline MLL3 & 8.4914 & 2.621705 \\
\hline BRCA1 & 8.486075 & 2.62364 \\
\hline PBX2 & 8.477455 & 2.800326 \\
\hline RMI1 & 8.447185 & 2.839224 \\
\hline BRIP1 & 8.38464 & 6.569919 \\
\hline ATM & 8.367658 & 2.461272 \\
\hline MYBL2 & 8.344836 & 2.480506 \\
\hline ESPL1 & 8.32113 & 2.565788 \\
\hline CASC5 & 8.271757 & 2.521866 \\
\hline STAT2 & 8.224094 & 2.613837 \\
\hline TOP2A & 8.215572 & 2.277137 \\
\hline CENPE & 8.178639 & 2.624413 \\
\hline CCNE2 & 8.048637 & 2.69551 \\
\hline FOXP1 & 8.036818 & 2.616995 \\
\hline RUNX1 & 7.862116 & 2.470978 \\
\hline HELLS & 7.837011 & 2.388881 \\
\hline DNMT3B & 7.694172 & 2.575032 \\
\hline RARA & 7.615044 & 2.482983 \\
\hline UHRF1 & 7.476315 & 2.4227 \\
\hline
\end{tabular}


Appendix

\begin{tabular}{ccc}
\hline MLL5 & 7.364065 & 2.461649 \\
\hline CHAF1B & 7.299285 & 2.490731 \\
\hline TLX2 & 7.157793 & 2.456056 \\
\hline BAZ2A & 7.151682 & 2.400109 \\
\hline SUV39H2 & 7.065186 & 2.363607 \\
\hline MYBL1 & 6.937232 & 2.546511 \\
\hline BCL2L11 & 6.84793 & 2.359521 \\
\hline CHAF1A & 1.32764 & 2.379459 \\
\hline TCF7 & 6.461873 & 2.175603 \\
\hline
\end{tabular}




\section{Curriculum Vitae}

Name: Medhanie Assmelash Mulaw

Date of Birth: September 30, 1976

Nationality: Ethiopian

Marital Status: Married

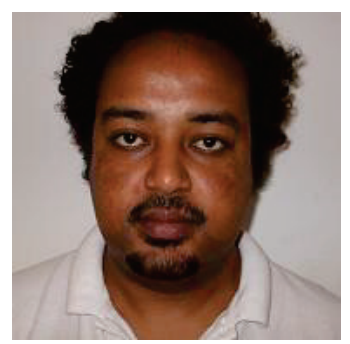

Formal Academic Background (post secondary school):

2006 - 2009 - PhD in Human Biology from the Department of Medicine III, Faculty of Medicine, University of Munich, Munich, Germany

1998/1999 - 1999/2000 - Masters of Science in Biology (Applied Genetics), from the

Department of Biology, Faculty of Science, Addis Ababa University (AAU), Addis

Ababa, Ethiopia

1993/94 - 1996/1997 - Bachelor of Science (B.Sc.) in Plant Sciences from the College of Agriculture and Aquatic Sciences of University of Asmara, Asmara, Eritrea

\section{Work Experience:}

2000 - : Part time and then full time Lecturer at the Department of Biology, Faculty of Science, Addis Ababa University (AAU). Courses thought include Molecular Biology, Principles of Genetics (Lab), Gene Technology, Biotechnology, Biostatistics, Techniques in Molecular Biology.

\section{Publications:}

Bararia D, Trivedi AK, Zada AA, Greif PA, Mulaw MA, Christopeit M, Hiddemann W, Bohlander SK, Behre G.(2008). Proteomic identification of the MYST domain histone acetyltransferase TIP60 (HTATIP) as a co-activator of the myeloid transcription factor C/EBPalpha. Leukemia 22(4): 676-677. 


\section{Seminars and conferences attended:}

Attended: July 2006, Annual meeting of the Department of Medicine III, University of Munich Herrsching, Germany

Poster Presentation: September 2006, Presented a poster at the SFB Transregio meeting on Chromatin Inheritance-Munich, Germany

Attended: February 2007, Harvard-Munich meeting- Eibsee, Germany

Poster Presentation: July 2007, Presented a poster (and won the poster prize) at the Annual meeting of the Department of Medicine III, University of Munich - Herrsching, Germany

Speaker: February 2008, Speaker at the Harvard-Munich meeting-Garmisch, Germany

Poster Presentation: April 2008, Presented a poster at the Annual Meeting of the society of Human Genetics - Hannover, Germany

Speaker: July 2008, Speaker at the Annual meeting of the Department of Medicine III, University of Munich - Herrsching, Germany

Speaker: November 2008, Nationales Genomforschungsnetz Deutschland (NGFN) meeting, Berlin, Germany

Poster Presentation: December 2008, 50 ${ }^{\text {th }}$ Annual conference of the American Society of Hematology (ASH), San Franscisco, CA, USA

\section{Course Attended:}

March 2007: Bioinformatics for Molecular Biologists - Annual course organized by the University of Munich, Technical University of Munich and HelmholtzZentrum Institute of Bioinformatics - Bertinoro, Italy 